\title{
Screening of plant collection of Cibodas Botanic Gardens, Indonesia with anticancer properties
}

\author{
RISHA AMILIA PRATIWI", YATI NURLAENI" \\ Cibodas Botanic Gardens, Research Center for Plant Conservation and Botanical Garden, Indonesian Institute of Sciences. Jl. Kebun Raya Cibodas, \\ Sindanglaya, Cipanas, Cianjur 43253, West Java, Indonesia Tel./fax.: +62 263 512233, `email: risha.amilia.pratiwi@ @lipi.go.id, •"yati.nurlaeni@lipi.go.id
}

Manuscript received: 24 August 2020. Revision accepted: 16 October 2020.

\begin{abstract}
Pratiwi RA, Nurlaeni Y. 2020. Screening of plant collection of Cibodas Botanic Gardens, Indonesia with anticancer properties. Biodiversitas 21: 5186-5229. Cancer is a life-threatening disease worldwide. One approach to developing effective treatment in fighting cancerous cells is to obtain anticancer drug candidates from natural resources, such as plants. This study aimed to inventory and categorize plant collections in Cibodas Botanic Gardens (CBG), West Java, Indonesia that has anticancer properties in a detailed and comprehensive manner. Literature research was conducted in international scientific databases using several keywords expressing anticancer properties to produce list of plant species potential for anticancer. The results of this research were then cross-checked with the plant collection database of CBG. List of plants exhibits anticancer activities were then categorized based on the $\mathrm{IC}_{50}$ values (an indicator of cytotoxicity). Our result showed 291 species from 90 families of CBG plant collection harbor anticancer properties. Among them, 93, 100, 36, and 62 species have IC 50 values under Class I (strong), Class II (moderate), Class III (inactive), and Class IV (insufficient $\mathrm{IC}_{50}$ data), respectively. The families with the highest number of potential anticancer plants are Lauraceae, Leguminosae, Meliaceae, Myrtaceae, Moraceae, Cupressaceae, Asparagaceae, Euphorbiaceae, Compositae, Clusiaceae, Lamiaceae, Apocynaceae, Adoxaceae, Amaryllidaceae, and Elaeocarpaceae. Species that have strong anticancer activities include Acacia farnesiana, Aglaia edulis, A. elliptica, A. silvestris, Artocarpus elasticus, Bauhinia strychnifolia, Buxus microphylla, Calophyllum soulattri, Cerbera manghas, Cocculus orbiculatus, Cryptocarya chinensis, C. konishii, C. laevigata, Dalbergia parviflora, Diospyros discolor, Erythrina abyssinica, Etlingera elatior, Ficus fistulosa, Garcinia x mangostana, Hemerocallis fulva, Jatropha gossypiifolia, Panax ginseng, Podocarpus macrophyllus, Psidium cattleianum, Sansevieria ehrenbergii, Tacca chantrieri, Toona sinensis, Viburnum odoratissimum, and $V$. Sambucinum. Even Serenoa repens and Taxus sumatrana contain active compounds that have been commercialized as anticancer drugs. The data resulted from this study can serve as baseline information for further research in drug discovery and development for anticancer treatments using living plant specimens collected in CBG. CBG has a great prospect of medicinal plants that require further studies for formulating anticancer drug as an alternative natural resource.
\end{abstract}

Keywords: Anticancer property, Cibodas Botanic Gardens, inhibitory concentration, plant metabolite secondary

\section{INTRODUCTION}

Cancer is the second leading cause of mortality globally after cardiovascular diseases. The International Agency for Research on Cancer (IARC) (2018) estimated the global cancer burden has risen to 18.1 million new cases and 9.6 million deaths in 2018. Indonesian Ministry of Health research data (Riskesdas) (2018) shows that the prevalence of cancer in Indonesia has increased from 1.4 to 1.8 cases per thousand of population in 2015 and 2018. By 2030, it is projected that there will be 26 million new cancer cases with 17 million deaths per year (Thun et al. 2010).

Considering cancer as a life-threatening disease worldwide, there is a continuing demand for developing treatments that are effective in fighting cancerous cells with less harmful than existing therapies. Solid tumors can be removed surgically, or by radiation treatment and chemotherapy that painful and induce toxic effects to patients. Drugs can be used as treatment for certain types of cancer, such as biological drugs, Herceptin, against breast cancer. However, the drug is very costly while the effectiveness is limited to certain kinds of tumors. Furthermore, it was found in many cases that the tumor can develop resistance to various drugs. Covering the problems, one approach is to obtain the anticancer drug candidates from secondary metabolite of natural resources, such as plants (Fridlender et al. 2015).

Utilizing plant as new drug resources in cancer treatment provides many advantages, including it is more cost-effective than developing synthetic compounds, faster discovery of new drugs, offering a holistic approach that complements the "silver bullets" of modern drug, and synergistic effects between the various compounds of the herbs give promising better healing effects overall (Fridlender et al. 2015). The natural products are also expected to build co-evolution against cancer cells so that the incidence of cancer drug resistance is expected to be minimal (Wang et al. 2015).

More than 3000 species of plant over the world have been reported to have anticancer properties (Solowey et al. 2014). The promising sources of anticancer properties from plants belong to various groups of compound, such as alkaloids, diterpenes, diterpenoquinone, purine-based compounds, lactonic sesquiterpene, peptides, cyclic depsipeptide, proteins, macrocyclic polyethers, and so on (Lichota et al. 2018). In searching for anticancer properties 
in plant, there is a long journey involving several steps that generally need to go through. Initially, plant-derived substances are discovered by botanists or ethnobotanists, ethnopharmacologists, or plant ecologists. Then, phytochemists identify the potential therapeutic activities through the isolation of active compounds and biological screening assays. Finally, the mode of action and relevant molecular targets are proven through molecular biology research (Lichota et al. 2018).

A complex set of ethnobotanical methods such as initial investigations, sample collections, and detailed records of the use a society makes of plants has been the starting point for many successful novel drug discovery projects. Ethnobotanists make information about this local knowledge and cultural practices available to bioscientists. The discovery of the proven anticancer drug Vincristine is an interesting history to reflect on it. Catharanthus roseus or known as Madagascar periwinkle has, since a long time ago, been used to treat various diseases traditionally, from minor symptoms such as headache to diabetes remedy. In 1960, Robert Noble and Charles Beer have isolated alkaloid vincristine from these ornamental plants. Further assay revealed that these ayurvedic plants exhibit a cytotoxic effect by microtubule dynamic inhibition, causing the mitotic spindle damage. Consequently, it inhibits mitosis and leading cancer cells to apoptosis (Lichota et al. 2018).

Cibodas Botanic Gardens (CBG) located in West Java has plant collection of 237 families, consisting of 949 genera, 1978 species, and 11428 plant living specimens (Registration and Collection Unit of CBG 2020; unpublished data). Such species have the potentials to be developed for various uses, such as fruit crops (Normasiwi and Surya 2016), sources of timber (Wahyuni et al. 2008), exudates (Muhaimin and Nurlaeni 2018), natural dyes (Efendi et al. 2017), ornamental plants (Putri et al. 2019, unpublished data), and medicinal plants (Nikmatullah et al. 2019). Several medicinal plants are known to have potential properties as anticancer drug, including Taxus sumatrana which contains paclitaxel (Muhaimin 2016); Mentha x piperita and Rotheca serrata (Lamiaceae) (Handayani 2015); Frullania sp., Heteroscyphus argutus, Pogonatum cirratum, and Marchantia paleacea (Bryophyte) (Nadhifah et al. 2018); Alnus japonica, Garcinia parviflora, Gnetum gnemonoides, Mangifera laurina, Syzygium cf. discophorum, and Talinum paniculatum from Medicinal Thematic Garden (Nikmatullah et al. 2019). However, until 2019 there has been no comprehensive exploration of the CBG collection that demonstrates anticancer properties.

This research was conducted to inventory and categorize plant collections in CBG that harbor anticancer properties in a detailed and comprehensive manner. The data resulted from this study is expected to serve as baseline information for further research to assess plant secondary metabolites for anticancer treatments, including phytochemical profiling and extraction method, in vitro assay to cancer cell models, in vivo assay to animal models, in silico assay as treatment simulation, or plant tissue culture for anticancer metabolite production.

\section{MATERIALS AND METHODS}

\section{Study area}

This research conducted in Cibodas Botanic Gardens (CBG) located at Cianjur District, West Java, Indonesia. $\mathrm{CBG}$ is a botanical garden managed by the Indonesian Institute of Sciences (LIPI). Besides having an ex-situ conservation role, $\mathrm{CBG}$ also has the function of research and utilization of tropical floras, especially wet plateau plants. Data investigation regarding the potential of plants cytotoxicity against cancer was carried out through online reference searches.

\section{Procedures}

In order to collect information about plant cytotoxicity against cancer, we used keywords: "plant cytotoxicity", "herbs for cancer", "phytotoxicity", "plant-derived chemoprevention", "medicinal plant for cancer", "anticancer natural drug", "plants secondary metabolite for anticancer", "plants with anticancer property", and "IC $\mathrm{I}_{50}$ of plant metabolite" in international databases, such as ScienceDirect, PubMed, and Scopus, and database of natural products and fractional extracts for cancer treatment that has been established by previous researchers, such as NPACT (Mangal et al. 2013) and NPCARE (Choi et al. 2017). Searches were limited to articles in English and Indonesian language with the research interval period from 1990 to 2020. The scientific name of the plant species mentioned in the references was recorded and verified for their existence in the CBG through the garden collection data. The compilation of plant database of $\mathrm{CBG}$ with anticancer properties was developed by completing the following data: family of plant, scientific name of plant species, vernacular name, cancer cell line, extraction method, $\mathrm{IC}_{50}$, reference, anticancer activity category, plant origin, conservation status, and locality at CBG. $\mathrm{IC}_{50}$ (50percent Inhibitory Concentration) selected as the cytotoxic parameter in in vitro assay; as the initial procedure for screening anticancer drug candidates.

\section{Data analysis}

Potential anticancer plants were classified into four categories based on National Cancer Institute guidelines: Class I for plants with strong activity against cancer cell line, Class II for moderate activity, Class III for inactive and Class IV for plants with insufficient $\mathrm{IC}_{50}$ data but mentioned has anticancer compound in literature (Jabit et al. 2009, Alabsi et al. 2016). Class I was divided into four subclasses to observe the selectivity index: I.A for plants that their pure extract (sub-fraction method) have $\mathrm{IC}_{50} \leq 4$ $\mu \mathrm{g} / \mathrm{ml}$ against at least three cancer line cells, I.B for pure extracts that have IC $50 \leq 4 \mu \mathrm{g} / \mathrm{ml}$ against one or two cancer line cell(s), I.C for plants that their crude extract has $\mathrm{IC}_{50} \leq$ $10 \mu \mathrm{g} / \mathrm{ml}$ against at least three cancer line cells, and I.D for crude extracts that have $\mathrm{IC}_{50} \leq 10 \mu \mathrm{g} / \mathrm{ml}$ against one or two cancer line cell(s). Then, Class II is for plants that pure or crude extract that has $10>\mathrm{IC}_{50}>100 \mu \mathrm{g} / \mathrm{ml}$ and class III for $\mathrm{IC}_{50} \geq 100 \mu \mathrm{g} / \mathrm{ml}$. Plant species belonged to Class I.A and not listed as threatened species according to The IUCN 
Red List of Threatened Species ${ }^{\mathrm{TM}}$ assessment were recommended for further studies.

\section{RESULTS AND DISCUSSION}

Family distribution of plant with anticancer properties

We found 90 families that consisted of 291 species of the collection of $\mathrm{CBG}$ that have anticancer properties according to the literature research we conducted (for detailed information, see Table 3 in appendix section). The families with the largest number of species are as follows: Lauraceae (21 species), Leguminosae (20 species), Meliaceae (17 species), Myrtaceae (13 species), Moraceae (13 species), Cupressaceae (11 species), Asparagaceae (10 species), Euphorbiaceae (10 species), Compositae (9 species), Clusiaceae (8 species), Lamiaceae (8 species), Apocynaceae (7 species), Adoxaceae (6 species), Amaryllidaceae (6 species), and Elaeocarpaceae (6 species). The other 75 families consisted of less than five species of plant per family. The distribution of plant families that have anticancer properties from $\mathrm{CBG}$ is shown in Figure 1.

Plant categories based on their cytotoxicity activities (IC 5 )

Our result showed that based on cytotoxic activities $\left(\mathrm{IC}_{50}\right)$, plants belonged to Class of I, II, III, and IV consisted of 93, 100, 36, and 62 species, respectively, or $32 \%, 34 \%, 13 \%$, and $21 \%$ in percentage, respectively. Class I is divided into four subclasses: 30 species as I.A, 27 species as I.B, 12 species as I.C, and 24 species as I.D. The categories of plants based on their cytotoxicity against cancer cells are displayed in Figure 2 and the species are listed in Table 1.

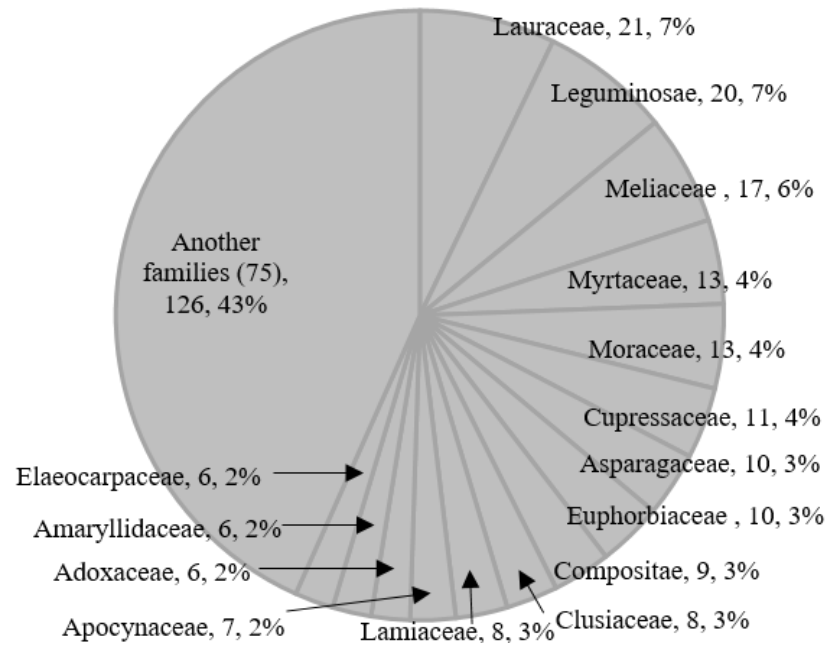

Figure 1. The distribution of plant families that have anticancer properties from CBG collection

\section{Discussion}

Among plant collection in Cibodas Botanic Garden, Lauraceae is the family consisting of the largest number of species with anticancer potential resources, dominated by the genus Cinnamomum, i.e. C. burmanii, C. camphora, $C$. cassia, C. iners, $C$. subavenium, and $C$. zeylanicum; Cryptocarya, including $C$. chinensis, C. costata, $C$. crassinervia, C. konishii, C. laevigata, and C. strictifolia; and Litsea, including L. cubeba, L. elliptica, L. garciae, L. mappacea, and L. monopetala. Actually, CBG still has another species of Cinnamomum collections (i.e. C. sintok, C. heyneanum, C. culitlawan, C. rhynchophyllum, $C$. javanicum, $C$. porrectum, and $C$. eymae); Cryptocarya $(C$. affinis, $C$. ferea, $C$. densilora, $C$. gigantocarpa, and $C$. vulgaris); and Litsea ( $L$. ferruginea, L. lanceolata, $L$. grandis, L. javanica, $L$. tomentosa, $L$. cassiaefolia, $L$. firma, L. oppositifolia, L. noronhae, L. umbellata, $L$. deccanensis, L. insignis, $L$. grisea, L. castanea, $L$. accendetoides, L. deccanensis, L. leefeana, L. ochraceae, and $L$. diversifolia).

Considering seven species of Cinnamomum, six species of Cryptocarya, and five species of Litsea have the potency as anticancer with strong and moderate categories, it is possible that other species within these families have similar properties. However, there are no references yet that tested the anticancer potency from these species. Shen et al. (2014) stated that Lauraceae is a potential resource for nontoxic compounds that activate the nuclear factor erythroid 2-related factor 2/antioxidant response element (Nrf2/ARE) pathway. Nrf2 plays a key role in binding with ARE sequences then activates the transcription of many cytoprotective genes. Nrf2/ARE pathway induction has been recognized as strategy for blocking or slowing cancer premalignant tumors, so-called chemoprevention as defense mechanism (Shen et al. 2014).

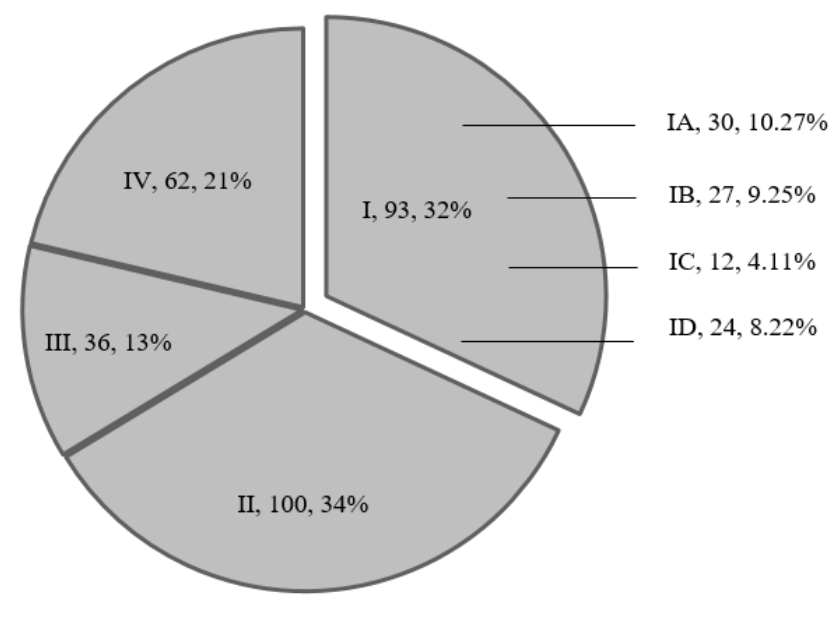

Figure 2. Plant categories based on their $\mathrm{IC}_{50}$ 
Table 1. Plant categories based on their cytotoxicity activities ( $\left.\mathrm{IC}_{50}\right)$

\begin{tabular}{|c|c|c|c|}
\hline \multicolumn{4}{|c|}{ Plant categories } \\
\hline $\mathbf{I}$ & II & III & IV \\
\hline I.A & Acalypha wilkesiana & Acacia caffra & Acalypha hispida \\
\hline Acacia farnesiana & Achillea millefolium & Acanthus montanus & Achillea ptarmica \\
\hline Aglaia edulis & Acorus calamus & Ardisia crenata & Agapanthus africanus \\
\hline Aglaia elliptica & Aglaia angustifolia & Areca vestiaria & Agave attenuata \\
\hline Aglaia silvestris & Aglaia eximia & Asclepias curassavica & Aglaia lawii \\
\hline Artocarpus elasticus & Aglaia odorata & Bauhinia variegata & Aglaia odoratissima \\
\hline Bauhinia strychnifolia & Alangium chinense & Bixa orellana & Aglaia tomentosa \\
\hline Buxus microphylla & Alnus japonica & Cratoxylum formosum & Alangium javanicum \\
\hline Calophyllum soulattri & Aloe ferox & Cupressus sempervirens & Aleurites moluccanus \\
\hline Cerbera manghas & Aloe vera & Decaspermum fruticosum & Aloe arborescens \\
\hline Cocculus orbiculatus & Alstonia angustifolia & Dracaena draco & Aristolochia trilobata \\
\hline Cryptocarya chinensis & Ardisia crispa & Elaeocarpus glaber & Bauhinia integrifolia \\
\hline Cryptocarya konishii & Artocarpus altilis & Embelia ribes & Capsicum аппиит \\
\hline Cryptocarya laevigata & Artocarpus heterophyllus & Ficus benjamina & Cibotium barometz \\
\hline Dalbergia parviflora & Blechnum orientale & Ficus hirta & Coccoloba uvifera \\
\hline Diospyros discolor & Buddleja davidii & Ichnocarpus frutescens & Coffea canephora \\
\hline Erythrina abyssinica & Buxus papillosa & Leea indica & Crinum abyssinicum \\
\hline Etlingera elatior & Caesalpinia gilliesii & Litsea mappacea & Cryptocarya strictifolia \\
\hline Ficus fistulosa & Caesalpinia spinosa & Mahonia fortunei & Cyperus alternifolius \\
\hline Garcinia $\mathrm{x}$ mangostana & Camellia sinensis & Morus nigra & Dillenia serrata \\
\hline Gmelina arborea & Catha edulis & Myrica esculenta & Diospyros celebica \\
\hline Hemerocallis fulva & Centella asiatica & Oroxylum indicum & Elaeocarpus densiflorus \\
\hline Jatropha gossypiifolia & Cestrum nocturnum & Passiflora suberosa & Elaeocarpus petiolatus \\
\hline Panax ginseng & Cheilocostus speciosus & Phaleria macrocarpa & Elaeocarpus serratus \\
\hline Podocarpus macrophyllus & Chisocheton lasiocarpus & Pinus merkusii & Elaeocarpus sylvestris \\
\hline Psidium cattleianum & Cinnamomum camphora & Pinus yunnaennsis & Equisetum ramosissimum \\
\hline Sansevieria ehrenbergii & Cinnamomum iners & Polyalthia subcordata & Eucalyptus globulus \\
\hline Tacca chantrieri & Cinnamomum burmanni & Rhodamnia cinerea & Eucomis comosa \\
\hline Toona sinensis & Cinnamomum zeylanicum & Rotheca serrata & Euphorbia milii \\
\hline Viburnum odoratissimum & Citrus medica & Strobilanthes cernua & Ficus religiosa \\
\hline Viburnum sambucinum & Clerodendrum trichotomum & Syzygium polyanthum & Flemingia macrophylla \\
\hline I.B & Colletia paradoxa & Taraxacum campylodes & Garcinia dioica \\
\hline Acacia tenuifolia & Crinum $\times$ powellii & Toona ciliata & Garcinia latissima \\
\hline Aglaia argentea & Cryptocarya crassinervia & Uvaria grandiflora & Gerbera jamesonii \\
\hline Aglaia forbesii & Cupressus lusitanica & Viburnum cylindricum & Hemerocallis minor \\
\hline Artocarpus lanceifolius & Derris elliptica & Yucca gloriosa & Hymenocallis speciosa \\
\hline Camptotecha acuminata & Dioscorea bulbifera & & Iris pseudacorus \\
\hline Cananga odorata & Diospyros kaki & & Juniperus procumbens \\
\hline Chisocheton patens & Dodonaea viscosa & & Leonurus cardiaca \\
\hline Cinnamomum cassia & Eclipta prostrata & & Lindera polyantha \\
\hline Cinnamomum subavenium & Elaeocarpus reticulatus & & Litsea elliptica \\
\hline Cinnamomum verum & Erythrina crista-galli & & Litsea monopetala \\
\hline Clausena excavata & Erythrina fusca & & Macaranga triloba \\
\hline Cryptocarya costata & Eucalyptus microcorys & & Mentha canadensis \\
\hline Cryptomeria japonica & Eucalyptus robusta & & Opuntia robusta \\
\hline Dichroa febrifuga & Eugenia uniflora & & Phyllostachys edulis \\
\hline Eriobotrya japonica & Ficus deltoidea & & Pinus parviflora \\
\hline Euphorbia pulcherrima & Ficus drupacea & & Pterocarpus indicus \\
\hline Garcinia lateriflora & Garcinia celebica & & Pterocarya stenoptera \\
\hline Hernandia nymphaeifolia & Garcinia rostrata & & Quercus acuta \\
\hline Hibiscus syriacus & Gardenia jasminoides & & Salvia splendens \\
\hline Hypericum uralum & Gleditsia sinensis & & Sambucus javanica \\
\hline Macaranga tanarius & Glochidion eriocarpum & & Sanguisorba minor \\
\hline Morus alba & Gnetum gnemon & & Shorea platyclados \\
\hline Ochrosia elliptica & Hedychium coronarium & & Sophora tetraptera \\
\hline Olea еuropea & Hibiscus rosa-sinensis & & Stephania hernandiifolia \\
\hline Pityrogramma calomelanos & Hypericum oblongifolium & & Styrax benzoin \\
\hline Taxus sumatrana & Iris halophila & & Ternstroemia gymnanthera \\
\hline Ziziphus jujuba & Juniperus chinensis & & Thuja standishii \\
\hline I.C & Kalanchoe beharensis & & Viburnum suspensum \\
\hline Alstonia scholaris & Lantana camara & & Yucca glauca \\
\hline Crinum zeylanicum & Laurus nobilis & & Ziziphus oenopolia \\
\hline Dillenia philippinensis & Liquidambar formosana & & \\
\hline
\end{tabular}




\begin{tabular}{|c|c|}
\hline Enterolobium contortisiliquum & Litsea cubeba \\
\hline Glochidion zeylanicum & Litsea garciae \\
\hline Goniothalamus macrophyllus & Macaranga rhizinoides \\
\hline Hamelia patens & Marantodes pumilum \\
\hline Juniperus virginiana & Mentha $\mathrm{x}$ piperita \\
\hline Melastoma malabathricum & Murraya paniculata \\
\hline Piper aduncum & Musa acuminata \\
\hline Symplocos cochinchinensis & Myrica rubra \\
\hline Tabebuia hypoleuca & Opuntia microdasys \\
\hline I.D & Persea americana \\
\hline Agave americana & Phyllanthus emblica \\
\hline Agave salmiana & Phyllostachys nigra \\
\hline Caesalpinia sappan & Pinus kesiya \\
\hline Callistemon citrinus & Pistacia chinensis \\
\hline Coix lacryma-jobi & Plantago lanceolata \\
\hline Cola acuminata & Platycladus orientalis \\
\hline Cola nitida & Polyalthia rumphii \\
\hline Crinum macowanii & Psidium guajava \\
\hline Croton argyratus & Salvia farinacea \\
\hline Diplazium esculentum & Sambucus nigra \\
\hline Eucomis autumnalis & Sandoricum koetjape \\
\hline Ficus septica & Sarcandra glabra \\
\hline Flacourtia rukam & Shorea javanica \\
\hline Garcinia dulcis & Smallanthus sonchifolius \\
\hline Juniperus procera & Smilax zeylanica \\
\hline Lobelia laxiflora & Sophora tomentosa \\
\hline Melaleuca alternifolia & Syzygium cumini \\
\hline Schima wallichii & Syzygium jambos \\
\hline Schinus terebinthifolia & Tecoma stans \\
\hline Schinus weinmannifolius & Terminalia calamansanay \\
\hline Serenoa repens & Thuja occidentalis \\
\hline Tabernaemontana macrocarpa & Toona sureni \\
\hline Thujopsis dolabrata & Vaccinium varingiaefolium \\
\hline \multirow[t]{4}{*}{ Tithonia diversifolia } & Vernonia amygdalina \\
\hline & Vernonia arborea \\
\hline & Viola odorata \\
\hline & Yucca aloifolia \\
\hline
\end{tabular}

Note: Class I for plants with strong activity against cancer cell line, Class II for moderate activity, Class III for inactive and Class IV for plants with insufficient $\mathrm{IC}_{50}$ data but mentioned has anticancer compound in literature (Jabit et al. 2009, Alabsi et al. 2016)

From Leguminosae family, several genera that have anticancer properties include Acacia, Bauhinia, Caesalpinia, Dalbergia, Derris, Enterolobium, Erythrina, Flemingia, Gleditsia, Pterocarpus, and Sophora. Meliaceae has Aglaia, Chisocheton, Sandoricum, and Toona. Even there are eleven species of Aglaia plant with anticancer properties, making it the genus with the largest number of species compared to the others. Several major families and other dominant genera are Myrtaceae (Callistemon, Eucalyptus, Eugenia, Decaspermum, Melaleuca, Psidium, Rhodamnia, and Syzygium); Moraceae (Artocarpus, Ficus, and Morus), Cupressaceae (Cryptomeria, Cupressus, Juniperus, Platycladus, Thuja, and Thujopsis); Asparagaceae (Agave, Dracaena, Eucomis, Sansevieria, and Yucca); and Euphorbiaceae (Euphorbia, Acalypha, Aleurites, Croton, Jatropha, and Macaranga). Several species of Ficus from Gunung Gede Pangrango National Park, which is located near CBG, have been observed as anticancer sources, such as $F$. laevigata, $F$. lepicarpa, $F$. obscura, $F$. ribes, and $F$. variegata (Arbiastutie et al. 2017).

The majority of plants with anticancer potentials in CBG were classified as having strong and moderate cytotoxic activities (Class I and II), with proportion of $32 \%$ and $34 \%$, respectively. Even paclitaxel from Taxus sumatrana is already at the commercialization stage, sold under the brand name Taxol® since 1993 (Seca et al. 2017) and the extract from Serenoa repens has been formulated as Permixon ${ }^{\circledR}$, a commercial drug for benign prostatic hyperplasia (BPH) treatment (Habib et al. 2005; Zhou et al. 2015). Our findings suggest that plant collection in CBG has a great potential to be further explored for naturalbased drug discovery and development, particularly for anticancer. This is in line with the history of early development of $\mathrm{CBG}$ which was aimed for the domestication of medicinal plants, most notably was quinine. Similar to botanical gardens in the world, such as Kew, Singapore, Peradeniya, Calcutta, and Sidney, their initial development was driven by the goal of domestication of industrial and medicinal plants such as rubber, tea, coffee, and quinine (Smith 2019).

The listed species in this study have a history of successful isolation of pure active compounds with strong activity against more than three model cancer cell lines (Class I.A) which are dominated by Aglaia, Cryptocarya, and Viburnum. The active rocaglaol compound isolated 
from various Aglaia was known to produce very high cytotoxicity compared to the positive control paclitaxel and camptothecin (Huspa 2009). Cryptocarya sinensis not only actively inhibits cancer cells but also the active compound dehydrophenanthroindolizidine contains a significant antiHIV activity (T.S. Wu et al. 2012). C. laevigata contains the active compound (-) - neocaryachine which is also toxic to multidrug-resistant sublines through the double-strand breaks DNA induction mechanism (Suzuki et al. 2018).

Several plant secondary metabolites that have been widely studied as anticancer compounds include vincristine, viscotoxin, paclitaxel, camptothecin, combrestatin, podophyllotoxin, geniposide, colchicine, artesunate, homoharringtonine, salvicine, ellipticine, roscovitine, maytansberine, thapsicine acid, bruceantin, flavonols, crocetin, gingerol, lycopene, and ingenol mebutate (Seca et al. 2017; Iqbal et al. 2017; Lichota et al. 2018). Plants in CBG that contain these compounds include Taxus sumatrana (paclitaxel), Camptotecha acuminate (camptotechin), Juniperus procumbens and Hernandia nymphaeifolia (podophyllotoxin), Gardenia jasminoides (geniposide or genipin), Buddleja davidii (colchicine), Salvia (salvicine), Ochrosia elliptica (ellipticine), Dillenia serrata, Acacia farnesiana, and Eriobotrya japonica (betulinic acid), Capsicum annuum (capsaicin), Thuja occidentalis (flavonol), and Euphorbiaceae (ingenol mebutate). Combretum sp. at CBG as a potential source of combretastatin, is not included yet in the database because it is not completely taxonomically identified, while Artemisia annua (artesunate) is not yet a CBG collection despite the related research was initiated at CBG's Medicinal Thematic Garden (unpublished data). In CBG, there are several Berberis species, however, there has been no research on the berberine content which has the potential as an anticancer. Unfortunately, there is no Catharanthus roseus (formerly Vinca rosea) that its vincristine isolate is approved for clinical purposes as cancer treatment, Viscum album (source of viscotoxin), Cephalotaxus (homoharringtonine), Raphanus sativus (roscovitine), Maytenus serrata (maytansine), Thapsia garganica (thapsigargin), Brucea antidysenterica or $B$. javanica (bruceantin), Crocus sativus or known as saffron (crocetin), Zingiber officinale (gingerol) but another Zingiber was found at CBG; tomatoes, watermelons, and red carrots (lycopene). It could be a suggestion for CBG to collect these plants.

Some plants of CBG collection contain anticancer compounds, however, the extracts of these plants have not been tested against cancer line. These plants include Viburnum suspensum (contains vibsanin), Agapanthus africanus (isoliquiritigenin), Hymenocallis speciosa (narciclasine (lycoricidinol) and pancratistatin), Aristolochia trilobata (lusicininal and rubraxanthone), Garcinia latissima (kaemferol), Achillea ptarmica (pellitorine), Alangium javanicum (javanicides and alangicides), Dillenia serrata (koetjapic acid and betulinic acid), Shorea platyclados (resveratrol), Diospyros celebica (plumbagin), Elaeocarpus petiolatus (cucurbitacin), E. serratus (farnesol), E. sylvestris (brevifolin), Quercus acuta (chlorogenic acid), Pterocarya stenoptera (pterocarmin A), Mentha canadensis (rosmarinic acid and cathecin), Salvia splendens (quercetin), Phyllostachys edulis (tricin and 7-O-methyl-tricin), Ziziphus oenopolia (betulinic acid), Coffea canephora (kahweol, cafestol, 16O-methylcafestol), and Aloe ferox (aloe emodine, emodine, aloin). It is therefore suggested to further exploration of their anticancer activities.

Nature supply a huge number of compounds that provide new hope for medical uses, including cancer treatment. The trade-in plant-derived drugs generates astonishing economic value, which is estimated of US \$ 100 billion at current state and still grows to US $\$ 5$ trillion by 2050 (Greenwell et al. 2015). However, the availability of anticancer compounds in nature is limited and technically difficult to be isolated, makes it difficult to meet the demand of pharmaceutical industries. The solubility of natural anticancer compounds, such as paclitaxel and curcumin, is also low, makes it impractical for human cells to absorb. In the use of natural materials to become effective anticancer compounds, it is necessary to modify, formulate and manufacture semisynthetic or synthetic analogs, as well as a tissue culture approach for the massive production of secondary metabolites (Fridlender et al. 2015). Thanks to the advances in plant biotechnology, pharmacology, as well as nanotechnology that makes natural resource research for medicinal sources accelerating (Seca et al. 2017).

On the other hand, the exploitation of plant-derived drugs risks their existence in the wild in the long term, therefore proper management conservation strategies to fulfill demand for medicinal plants with the assurance of their sustainability becomes necessity (Seca et al. 2017). For example, Taxus sumatrana, Shorea javanica, Shorea platyclados, and Pterocarpus indicus are classified as endangered (EN) category of IUCN Red List. Dracaena draco, Kalanchoe beharensis, Diospyros celebica, Aglaia angustifolia, and Pinus merkusii are categorized as vulnerable (VU). Whereas $T$. sumatrana is a strong category of anticancer sources, A. angustifolia, $K$. beharensis, and $S$. javanica have moderate anticancer properties. Instead of encouraging the massive utilization of them, better to find other resources because there are still many species listed here with strong anticancer potency but excluded from threatened plants.

It should be remembered that the development of natural-based anticancer drugs is a long, complicated, expensive, and uncertain process to be successful. The development of an anticancer drug is started from in vitro, in vivo, to clinical testing and it takes a long time. It is clear that in vitro testing is a preliminary stage only with all its limitations.. However, there is no clinical trial without going through the preliminary testing stages. This study is limited by the categorization based on cytotoxicity to particular cancer cell lines, no discussed selectivity index among cell lines. Therefore we require further investigation to compare its activity in normal cells as an important aspect to be considered in drug formulation. 


\section{ACKNOWLEDGEMENTS}

The authors thank all researchers and staff of registration and collection unit of the CBG for their kindness and help during the research.

\section{REFERENCES}

Abd Wahab W, Adzmi AN. 2017. The investigation of cytotoxic effect of Cinnamomum zeylanicum extracts on human breast cancer cell line (MCF7). Sci Heritage J 1 (2): 23-28.

Abdel-Mageed WM, Al-Wahaibi LH, Gouda YG, Al-Saleem MSM, ElGamal AA, Basudan OA, Alsaid MS, Al-Massarani SM, Abdel-Kader MS. 2019. Contortisiliosides H-M: Triterpenoid saponins from Enterolobium contortisiliquum and their biological activity. Ind Crops Prod 139.

Abebe W. 2016. An overview of Ethiopian traditional medicinal plants used for cancer treatment. Eur J Med Plants 14 (4): 1-16.

Abida P, De Britto AJ, Antoney J, Raj TLS. 2016. Evaluation of in vitro anticancer activity of Symplocos cochinchinensis (Lour.) S. Moore bark. Int J Herb Med 4 (6): 117-119.

Abou-Elella F, Mourad R. 2015. Anticancer and antioxidant potential of ethanolic extracts of Phoenix dactylifera, Musa acuminata and Cucurbita maxima. Res J Pharm Biol Chem Sci 6 (1): 710-720.

Abu Bakar MF, Ahmad NE, Suleiman M, Rahmat A, Isha A. 2015. Garcinia dulcis fruit extract induced cytotoxicity and apoptosis in HepG2 liver cancer cell line. BioMed Res Int 2015: 1-10.

Abu-Dahab R, Kasabri V, Afifi FU. 2014. Evaluation of the volatile oil composition and antiproliferative activity of Laurus nobilis L. (Lauraceae) on breast cancer cell line models. Rec Nat Prod 8 (2): 136-147.

Adnan M. 2019. Bioactive potential of essential oil extracted from the leaves of Eucalyptus globulus (Myrtaceae). J Pharmacog PhytoChem 8 (1): 213-216.

Afonso AF, Pereira OR, Fernandes ÂSF, Calhelha RC, Silva AMS, Ferreira ICFR, Cardoso SM. 2019. The health-benefits and phytochemical profile of Salvia apiana and Salvia farinacea var. Victoria Blue decoctions. Antioxidants 8 (8): 241-244.

Agarwal P, Chettiar S, Adhvaryu M. 2014. Anticancer activity of Gerbera jamesonii on A549-Adeno-Carcinomic human alveolar basal epithelial cell line-an in vitro study. J Altern Complement Med 20 (5) A36-A36.

Aguilar-Meléndez A, Azurdia C, Cerén-López J, Menjívar J, Contreras A. 2020. Capsicum annuum (amended version of 2019 assessment). The IUCN Red List of Threatened Species

Ahmed A, Ali M, El-Kholie E, El-Garawani I, Sherif N. 2016. Anticancer activity of Morus nigra on human breast cancer cell line (MCF-7): the role of fresh and dry fruit extracts. J BioSci Appl Res 2 (6): 352-361.

Aisha AFA, Alrokayan SA, Abu-Salah KM, Darwis Y, Abdul Majid AMS. 2009. In vitro cytotoxic and apoptotic properties of the stem bark extract of Sandoricum koetjape on breast cancer cells. Int J Cancer Res 5 (3): 123-129.

Alabsi AM, Lim KL, Paterson IC, Ali-Saeed R, Muharram BA. 2016. Cell cycle arrest and apoptosis induction via modulation of mitochondria integrity by $\mathrm{Bcl}-2$ family members and caspase dependence in Dracaena cinnabari-treated $\mathrm{H} 400$ human oral squamous cell carcinoma. BioMed Res Int 2016: 1-13.

Aladesanmi AJ, Famuyiwa FG, Oriola AO, Oguntimehin SA, Aiyedun PO, Arthur G. 2019. Cytotoxic activity of selected Nigerian medicinal plants. J Herbs Spices Med Plants 26 (2): 203-217.

Al-Gara'awi NI, Abu-Serag NA, Alee Shaheed KA, Bahadly ZKA. 2019 Analysis of bioactive phytochemical compound of (Cyperus alternifolius L.) By using gas chromatography-mass spectrometry. IOP Conf Ser: Mater Sci Eng 571, 012047.

Al-Khdhrairawi AAQ. 2017. Isolation, Structure Characterization and Cytotoxicity Assessment of Alkaloids from Ficus fistulosa var. tengerenisis (Miq.) Kuntze. [Thesis]. University of Nottingham Malaysian Campus. [Malaysia]

Allado-Ombat LA, Teves FG. 2015. Anti-angiogenic and non-cytotoxic potential of aqueous and acetone extracts of the stem of Philippine Forest Liana, Bauhinia integrifolia Roxb. Int J BioSci 7 (5): 184-191.
Alonso-Castro AJ, Villarreal ML, Salazar-Olivo LA, Gomez-Sanchez M, Dominguez F, Garcia-Carranca A. 2011. Mexican medicinal plants used for cancer treatment: pharmacological, phytochemical and ethnobotanical studies. J Ethno Pharmacol 133 (3): 945-972.

Alsanosy R, Alhazmi HA, Sultana S, Abdalla AN, Ibrahim Y, Al Bratty M, Banji D, Khardali I, Khalid A. 2020. Phytochemical screening and cytotoxic properties of ethanolic extract of young and mature khat leaves. J Chem 2020: 1-9.

Alsaraf M, Mohammad MH, Al-Shammari AM, Abbas IS. 2019. Selective cytotoxic effect of Plantago lanceolata L. against breast cancer cells. J Egypti Nat Cancer Inst 31: 10.

Althaus J, Kaiser M, Brun R, Schmidt T. 2014. Antiprotozoal activity of Achillea ptarmica (Asteraceae) and its main alkamide constituents. Molecules 19 (5): 6428-6438

Amaral RG, Gomes SVF, Luciano MC dos S, Ó Pessoa C do, Andrade LN, Severino P, Brandão GC, Bomfim LM, Soares MBP, Bezerra DP, David JM, Carvalho AA. 2019. Cytotoxic potential of 14 Passiflora species against cancer cells. J Med Plants Res 13 (7): 157166.

Ambrož M, Boušová I, Skarka A, Hanušová V, Králová V, Matoušková P, Szotáková B, Skálová L. 2015. The influence of sesquiterpenes from Myrica rubra on the antiproliferative and pro-oxidative effects of doxorubicin and its accumulation in cancer cells. Molecules 20 (8): 15343-15358.

Anjarsari EY, Kristina N, Larasati YA, Putri DDP, Meiyanto E. 2013. Synergistic effect of cinnamon essential oil (Cinnamomum burmannii) and doxorubicin on T-47D cells correlated with apoptosis induction. Indones J Cancer Chemoprevention 4 (1): 450-456.

Aqil F, Gupta A, Munagala R, Jeyaprakash J, Kausar H, Sharma R, Singh IP, Gupta RC. 2012. Antioxidant and antiproliferative activities of anthocyanin/ellagitannin-enriched extracts from Syzygium cumini L. ('jamun', the Indian Blackberry). Nutr Cancer 64 (3): 428-438.

Arbiastutie Y. 2017. The Potential of understorey plants from Gunung Gede Pangrango National Park (West Java, Indonesia) as cervix anticancer agents. Biodiversitas 18 (1): 109-115.

Arbiastutie Y. 2017. The Potential of understorey plants from Gunung Gede Pangrango National Park (West Java, Indonesia) as cervix anticancer agents. Biodiversitas 18 (1): 109-115.

Areces-Mallea AE. 1998. Tabebuia hypoleuca. The IUCN Red List of Threatened Species

Arullapan S, Muhamad S, Zakaria Z. Cytotoxic activity of the leaf and stem extracts of Hibiscus rosa-sinensis (Malvaceae) against leukaemic cell line (K-562). Trop J Pharm Res 12 (5): 743-746.

Asep S, Hening H, Gema PS, Gigih S, Chicy Widya M, Sahidin S. 2017. Anticancer activity of jatrophone an isolated compound from Jatropha gossypifolia plant against hepatocellular cancer cell HEP G2 1886. Biomed Pharmacol J 10 (02): 667-673.

Ashmawy N, Ashour M, Wink M, El-Shazly M, Chang F-R, Swilam N, Abdel-Naim A, Ayoub N. 2016. Polyphenols from Erythrina cristagalli: structures, molecular docking and phytoestrogenic activity. Molecules 21 (6): 726-739.

Ashraf A, Sarfraz RA, Rashid MA, Mahmood A, Shahid M, Noor N. 2016. Chemical composition, antioxidant, antitumor, anticancer and cytotoxic effects of Psidium guajava leaf extracts. Pharm Biol 54 (1): 1971-1981.

Ashton P. 1998. Shorea platyclados. The IUCN Red List of Threatened Species

Awang K, Hadi AHA, Saidi N, Mukhtar MR, Morita H, Litaudon M. 2008. New phenantrene alkaloids from Cryptocarya crassinervia. Fitoterapia 79 (4): 308-310.

Awang K, Loong X-M, Leong KH, Supratman U, Litaudon M, Mukhtar MR, Mohamad K. 2012. Triterpenes and steroids from the leaves of Aglaia exima (Meliaceae). Fitoterapia 83 (8): 1391-1395.

Bai S-T, Zhu G-L, Peng X-R, Dong J-R, Yu M-Y, Chen J-C, Wan L-S, Qiu M-H. 2016. Cytotoxicity of triterpenoid alkaloids from Buxus microphylla against human tumor cell lines. Molecules 21: 11251130

Baloch E. 2011. Gnetum gnemon. The IUCN Red List of Threatened Species

Bañares A. 1998. Dracaena draco. The IUCN Red List of Threatened Species

Bandopadhyaya S, Ramakrishnan M, Thylur RP, Shivanna Y. 2015. Invitro evaluation of plant extracts against colorectal cancer using HCT 116 Cell Line. Int J Plant Sci Ecol 1 (3): 107-112. 
Bárcenas LR, Goettsch BK, Gómez-Hinostrosa C, Guadalupe Martínez J. Sánchez E. 2017. Opuntia microdasys (amended version of 2013 assessment). The IUCN Red List of Threatened Species 2017.

Barstow M. 2018. Pterocarpus indicus. The IUCN Red List of Threatened Species Barstow, M. 2018. Sandoricum koetjape. The IUCN Red List of Threatened Species.

Barstow M. 2018. Shorea javanica. The IUCN Red List of Threatened Species.

Barstow M. 2018. Toona ciliata. The IUCN Red List of Threatened Species.

Barstow M. 2018. Toona sureni. The IUCN Red List of Threatened Species Barstow, M. 2019. Toona sinensis. The IUCN Red List of Threatened Species.

Baskar AA, Ignacimuthu S, Michael GP, Al Numair K. 2010. Cancer chemopreventive Potential of luteolin-7-o-glucoside isolated from Ophiorrhiza mungos Linn. Nutr Cancer: 1-9.

Berkov S, Romani S, Herrera M, Viladomat F, Codina C, Momekov G, Ionkova I, Bastida J. 2011. Antiproliferative alkaloids from Crinum zeylanicum: alkaloids from Crinum zeylanicum. Phytotherapy Res 25 (11): 1686-1692.

BGCI \& IUCN SSC Global Tree Specialist Group. 2018. Artocarpus elasticus. The IUCN Red List of Threatened Species.

BGCI \& IUCN SSC Global Tree Specialist Group. 2018. Cryptocarya laevigata. The IUCN Red List of Threatened Species.

BGCI \& IUCN SSC Global Tree Specialist Group. 2018. Ficus drupacea. The IUCN Red List of Threatened Species.

BGCI \& IUCN SSC Global Tree Specialist Group. 2018. Rhodamnia cinerea. The IUCN Red List of Threatened Species.

BGCI \& IUCN SSC Global Tree Specialist Group. 2018. Sambucus javanica. The IUCN Red List of Threatened Species.

BGCI \& IUCN SSC Global Tree Specialist Group. 2018 Tabernaemontana macrocarpa. The IUCN Red List of Threatened Species.

BGCI \& IUCN SSC Global Tree Specialist Group. 2019. Buxus microphylla. The IUCN Red List of Threatened Species.

BGCI \& IUCN SSC Global Tree Specialist Group. 2019. Dodonaea viscosa. The IUCN Red List of Threatened Species.

BGCI \& IUCN SSC Global Tree Specialist Group. 2019. Elaeocarpus sylvestris. The IUCN Red List of Threatened Species.

BGCI \& IUCN SSC Global Tree Specialist Group. 2019. Enterolobium contortisiliquum. The IUCN Red List of Threatened Species.

BGCI \& IUCN SSC Global Tree Specialist Group. 2019. Erythrina abyssinica. The IUCN Red List of Threatened Species.

BGCI \& IUCN SSC Global Tree Specialist Group. 2019. Erythrina cristagalli. The IUCN Red List of Threatened Species.

BGCI \& IUCN SSC Global Tree Specialist Group. 2019. Euphorbia pulcherrima. The IUCN Red List of Threatened Species.

BGCI \& IUCN SSC Global Tree Specialist Group. 2019. Ficus benjamina. The IUCN Red List of Threatened Species.

BGCI \& IUCN SSC Global Tree Specialist Group. 2019. Ficus septica. The IUCN Red List of Threatened Species.

BGCI \& IUCN SSC Global Tree Specialist Group. 2019. Garcinia dulcis. The IUCN Red List of Threatened Species

BGCI \& IUCN SSC Global Tree Specialist Group. 2019. Jatropha gossypiifolia. The IUCN Red List of Threatened Species.

BGCI \& IUCN SSC Global Tree Specialist Group. 2019. Quercus acuta. The IUCN Red List of Threatened Species.

BGCI \& IUCN SSC Global Tree Specialist Group. 2019. Syzygium cumini. The IUCN Red List of Threatened Species.

BGCI \& IUCN SSC Global Tree Specialist Group. 2019. Syzygium jambos (amended version of 2018 assessment). The IUCN Red List of Threatened Species.

BGCI \& IUCN SSC Global Tree Specialist Group. 2019. Tecoma stans The IUCN Red List of Threatened Species.

BGCI \& IUCN SSC Global Tree Specialist Group. 2020. Vachellia farnesiana. The IUCN Red List of Threatened Species.

BGCI, IUCN SSC Global Tree Specialist Group \& Lorea Hernández F. 2019. Piper aduncum. The IUCN Red List of Threatened Species.

BGCI, IUCN SSC Global Tree Specialist Group \& Meave JA. 2019 Cestrum nocturnum. The IUCN Red List of Threatened Species.

BGCI, IUCN SSC Global Tree Specialist Group, Cornejo-Tenorio G, Ibarra-Manríquez G, Lorea Hernández F. 2019. Hamelia patens. The IUCN Red List of Threatened Species.

Bhuyan DJ, Vuong QV, Bond DR, Chalmers AC, Bowyer MC, Scarlett CJ. 2018. Eucalyptus microcorys leaf extract derived HPLC-fraction reduces the viability of MIA $\mathrm{PaCa}-2$ cells by inducing apoptosis and arresting cell cycle. BioMed Pharmacotherapy 105 (2018): 449-460.

Bilz M. 2013. Achillea ptarmica. The IUCN Red List of Threatened Species Bilz, M. 2020. Sambucus nigra. The IUCN Red List of Threatened Species.

Bisi-Johnson MA, Obi CL, Hattori T, Oshima Y, Li S, Kambizi L, Eloff JN, Vasaikar SD. 2011. Evaluation of the antibacterial and anticancer activities of some South African medicinal plants. BMC Complement Altern Med 11 (1): 14-18.

Byahatti SM, Bogar C, Bhat K, Dandagi G. 2018. Evaluation of anticancer activity of Melaleuca alternifolia (i.e., tea tree oil) on colon cancer cell line (HT29) - an in vitro study. J Adv Clin Res Insights 5 (4): 99-103.

Cahyana AH, Ardiansah B. 2016. Antioxidative and cytotoxic effects of prenylated stilbene derivative-rich melinjo (Gnetum gnemon L.) fruit rind. AIP Conference Proceedings. Int Symposium on Current Progress in Mathematics and Sci.

Cai X-H, Wang Y-Y, Zhao P-J, Li Y, Luo X-D. 2010. Dolabellane diterpenoids from Aglaia odorata. Phyto Chem. 71 (8-9): 1020-1024.

Canteiro C, Lucas E. 2019. Psidium guajava. The IUCN Red List of Threatened Species.

Carter G, Farjon A. 2013. Thuja standishii. The IUCN Red List of Threatened Species Carter, G. 2013. Thujopsis dolabrata. The IUCN Red List of Threatened Species.

Castañeda DM, Pombo LM, Urueña CP, Hernandez JF, Fiorentino S. 2012. A gallotannin-rich fraction from Caesalpinia spinosa (Molina) Kuntze displays cytotoxic activity and raises sensitivity to doxorubicin in a leukemia cell line. BMC Compl Altern Med 12: 3847.

Chadburn H, Davis AP. 2017. Coffea canephora. The IUCN Red List of Threatened Species.

Chadburn H. 2012. Bauhinia variegata. The IUCN Red List of Threatened Species.

Chadburn H. 2012. Dalbergia parviflora. The IUCN Red List of Threatened Species.

Chahdoura H, Barreira JCM, Fernández-Ruiz V, Morales P, Calhelha RC, Flamini G, Soković M, Ferreira ICFR, Achour L. 2016. Bioactivity, proximate, mineral and volatile profiles along the flowering stages of Opuntia microdasys (Lehm): defining potential applications. Food Function 7 (3): 1458-1467.

Chanchal DK, Alok S, Rashi S, Bijauliya RK, Yadav RD, Sabharwal M. 2017. Various medicinal plants used in the treatment of anticancer activity. Int J Pharm Sci Res 9 (4): 1424-1429.

Chang M-Y, Shieh D-E, Chen C-C, Yeh C-S, Dong H-P. 2015. Linalool induces cell cycle arrest and apoptosis in leukemia cells and cervical cancer cells through CDKIs. Int J Mol Sci 16 (12): 28169-28179.

Cheek M. \& Lawrence P. 2019. Cola acuminata. The IUCN Red List of Threatened Species.

Cheek M. \& Lawrence P. 2019. Cola nitida. The IUCN Red List of Threatened Species.

Cheenpracha S, Karalai C, Rat-A-Pa Y, Ponglimanont C, Chantrapromma K. 2004. New cytotoxic cardenolide glycoside from the seeds of Cerbera manghas. Chem Pharm Bull 52 (8): 1023-1025.

Chen C-C, Wu J-H, Yang N-S, Chang J-Y, Kuo C-C, Wang S-Y, Kuo YH. 2010. Cytotoxic C 35 terpenoid cryptotrione from the bark of Cryptomeria japonica. Organic Lett 12 (12): 2786-2789.

Chen G, Xue J, Xu S-X, Zhang R-Q 2007. Chemical constituents of the leaves of Diospyros kaki and their cytotoxic effects. J Asian Nat Prod Res 9 (4): 347-353.

Chen L-G, Huang W-T, Lee L-T, Wang C-C. 2009. Ellagitannins from Terminalia calamansanai induced apoptosis in HL-60 cells. Toxicology In vitro 23 (4): 603-609.

Cho ES. 2019. Isolation, Structure Elucidation and Cytotoxic Activity of Cucurbitacins from Elaeocarpus petiolatus. [Thesis]. University of Nottingham Malaysian Campus. [Malaysia].

Choi H, Cho SY, Pak HJ, Kim Y, Choi J-Y, Lee YJ, Gong BH, Kang YS, Han T, Choi G, Choi Y, Lee S, Ryoo D, Park K. 2017. NPCARE: database of natural products and fractional extracts for cancer regulation. J Cheminform 9 (2): 1-9.

Choi SE, Kim KH, Kwon JH, Kim SB, Kim HW, Lee MW. 2008. Cytotoxic activities of diarylheptanoids from Alnus japonica. Arch Pharm Res 31 (10): 1287-1289.

Chopra MP, Mazumder PM, Sasmal D, Patro SK. 2016. Phytochemical, antioxidant and antimicrobial studies of Salvia splendens leaves. J Chem Pharm Res 7 (10): 724-728 
Cichewics RH, Zhang Y, Seera, NP, Nair MG. 2004. Inhibition of human tumor cell proliferation by novel anthraquinones from daylilies. Life Sci 74: 1791-1799.

Cortez AP, Menezes EGP, Benfica PL, Santos AP dos, Cleres LM, Ribeiro H de O, Lima EM, Kato MJ, Valadares MC. 2017. Grandisin induces apoptosis in leukemic K-562 cells. Braz J Pharm Sci 53 (1): 1-9.

Crowley D, Beech E, Oldfield S. 2018. Liquidambar formosana. The IUCN Red List of Threatened Species.

Cuccioloni M, Bonfili L, Mozzicafreddo M, Cecarini V. 2012. Sanguisorba minor extract suppresses plasmin-mediated mechanisms of cancer cell migration. Biochimica et Biophysica Acta 1820: 10271034.

Dante RAS, Ferrer RJE, Jacinto SD. 2019. Leaf extracts from Dillenia philippinensis Rolfe exhibit cytotoxic activity to both drug-sensitive and multidrug-resistant cancer cells. Asian Pacific J. of Cancer Prevention 20(11): 3285-3290.

de Kok R. 2019. Cinnamomum iners. The IUCN Red List of Threatened Species.

de Kok R. 2019. Gmelina arborea. The IUCN Red List of Threatened Species.

de Kok R. 2020. Cinnamomum subavenium. The IUCN Red List of Threatened Species.

de Kok R. 2020. Cryptocarya costata. The IUCN Red List of Threatened Species.

de Kok R. 2020. Litsea elliptica. The IUCN Red List of Threatened Species.

de Kok R. 2020. Litsea garciae. The IUCN Red List of Threatened Species.

de Kok R. 2020. Litsea monopetala. The IUCN Red List of Threatened Species.

Diantini A, Subarnas A, Lestari K, Halimah E, Susilawati Y, Supriyatna, Julaeha E, Achmad TH, Suradji EW, Yamazaki C, Kobayashi K, Koyama H, Abdulah R. 2012. Kaempferol-3-O-rhamnoside isolated from the leaves of Schima wallichii Korth. inhibits MCF-7 breast cancer cell proliferation through activation of the caspase cascade pathway. Oncology Lett 3: 1069-1072.

Du J, Singh H, Yi, T-H. 2016. Antibacterial, anti-biofilm and anticancer potentials of green synthesized silver nanoparticles using benzoin gum (Styrax benzoin) extract. Bioprocess Biosystem Eng.

Dumontet V, Thoison O, Omobuwajo OR, Martin M-T, Perromat G Chiaroni A, Riche C, Païs M, Sévenet T, Hamid A Hadi A. 1996. New nitrogenous and aromatic derivatives from Aglaia argentea and A. forbesii. Tetrahedron 52 (20): 6931-6942.

Ee GCL, Lim CM, Rahmani M, Shaari K, Bong CFJ. 2010. Pellitorine, an active anti-cancer lead compound against HL60 and MCT-7 cell lines and microbial transformation of piperine from Piper nigrum. Molecules 15 (4): 2398-2404.

Efendi M, Hapitasari IG, Rustandi R, Supriyatna A. 2016. Inventarisasi tumbuhan penghasil pewarna alami di Kebun Raya Cibodas. Jurnal Bumi Lestari 16 (1): 50-58. [Indonesian]

El Hawary S, El Sayed A, Helmy MW, El Naggar EM, Marzouk HS, Bassam SM. 2018. DNA fingerprinting, biological and chemical investigation of certain Yucca species. Nat Prod Res 32 (21): 2617 2620.

El-Nashar HAS, Mostafa NM, El-Badry MA, Eldahshan OA, Singab ANB. 2019. Chemical composition, antimicrobial and cytotoxic activities of essential oils from Schinus terebinthifolius Raddi Growing in Egypt. Int J Pharmacog Phytochem Res 11 (3): 235-239.

El-Shiekh RA, Al-Mahdy DA, Hifnawy MS, Tzanova T, Evain-Bana, Emilie, Philippot S, Bagrel D, Abdelsattar EA. 2017. Chemical and biological investigation of Ochrosia elliptica Labill. cultivated in Egypt. Rec Nat Prod 11 (6): 552-557.

Emam M, El Raey MA, Eisa WH, El-Haddad AE, Osman SM, El-Ansari MA, Rabie A-GM. 2017. Green synthesis of silver nanoparticles from Caesalpinia gilliesii (Hook) leaves: antimicrobial activity and in vitro cytotoxic effect against BJ-1 and MCF7 cells. J Appl Pharm Sci 7 (8): 226-233.

Endringer DC, Taveira FSN, Kondratyuk TP. Pezzuto JM, Braga FC. 2014. Cancer chemoprevention activity of labdane diterpenes from rhizomes of Hedychium coronarium. Rev Bras Farmacogn 24: 408412.

Endrini S, Marsiati H. 2008. Aktivitas antioksidan dan efek sitotoksik ekstrak kola (Cola nitida) pada kultur sel kanker hati (HepG-2). Jurnal Kedokteran YARSI 17 (1): 40-44.
Energy Development Corporation (EDC) 2020. Dillenia philippinensis. The IUCN Red List of Threatened Species

Evanjelene VK, Karthiga R. 2018. Chemo and bioinformatics resources for in silico drug discovery from Acalypha hispida beyond their traditional use. World Wide J Multidisciplinary Res Dev 4 (4): 120129.

Fadeyi SA, Fadeyi OO, Adejumo AA, Okoro C, Myles EL. 2013. In vitro anticancer screening of 24 locally used Nigerian medicinal plants. BMC Complement Altern Med 13 (1): 79-87.

Falodun A, Engel N, Kragl U, Nebe B, Langer P. 2013. Novel anticancer alkene lactone from Persea americana. Pharm Biol 51 (6): 700-706.

Fan C, Jin H, Wu L, Zhang Y, Ye RD, Zhang W, Zhang Y. 2017. An exploration of traditional Chinese medicinal plants with antiinflammatory activities. Evidence-Based Complement Altern Med (2017): 1-10.

Farjon A, Carter G. 2013. Juniperus procumbens. The IUCN Red List of Threatened Species.

Farjon A, Christian T, Rushforth K. 2013. Pinus yunnanensis. The IUCN Red List of Threatened Species.

Farjon A. 2013. Cupressus sempervirens. The IUCN Red List of Threatened Species.

Farjon A. 2013. Juniperus chinensis. The IUCN Red List of Threatened Species.

Farjon A. 2013. Juniperus procera. The IUCN Red List of Threatened Species.

Farjon A. 2013. Juniperus virginiana. The IUCN Red List of Threatened Species.

Farjon A. 2013. Pinus kesiya. The IUCN Red List of Threatened Species.

Farjon A. 2013. Pinus merkusii. The IUCN Red List of Threatened Species.

Farjon A. 2013. Platycladus orientalis. The IUCN Red List of Threatened Species.

Farjon A. 2013. Podocarpus macrophyllus. The IUCN Red List of Threatened Species.

Farjon A. 2013. Thuja occidentalis. The IUCN Red List of Threatened Species.

Fayad W, El-Hallouty SM, Meky NH, EL-Menshawi BS, Wassel GM, Hasabo AA. 2015. Evaluation of anticancer activity of some Egyptian plants showed free radical scavenging activity. Int J Pharm Tech Res 8 (3): 387-393.

Fayed SA. 2015. Chemical composition, antioxidant, anticancer properties and toxicity evaluation of leaf essential oil of Cupressus sempervirens. Notulae Bot Horti Agrobot Cluj-Napoca 43 (2): 320326.

Fayemi PO, Ozturk I, Kaan D, Özcan S, Yerer MB, Dokumaci AH, Özcan C, Uwaya GE, Fayemi OE, Yetim H. 2019. Bioactivities of phytochemicals in Callistemon citrinus against multi-resistant foodborne pathogens, alpha glucosidase inhibition and MCF7 cancer cell line. Biotechnol Biotechnol Equip 33 (1): 764-778.

Fensham R, Collingwood T, Laffineur B. 2019. Eucalyptus globulus. The IUCN Red List of Threatened Species.

Fensham R, Collingwood T, Laffineur B. 2019. Eucalyptus microcorys. The IUCN Red List of Threatened Species.

Fensham R, Laffineur B, Collingwood T. 2019. Eucalyptus robusta. The IUCN Red List of Threatened Species.

Fort RS, Barnech JMT, Dourron J, Colazzo M, Aguirre-Crespo FJ, Duhagon MA, Álvarez G. 2018. Isolation and structural characterization of bioactive molecules on prostate cancer from Mayan traditional medicinal plants. Pharmaceuticals 11: 78.

Fridlender M, Kapulnik Y, Koltai H. 2015. Plant derived substances with anti-cancer activity: from folklore to practice. Front Plant Sci 6: 799808.

Fu M, Qiu SX, Xu Y, Wu J, Chen Y, Yu Y, Xiao G. 2013. A new xanthone from the pericarp of Garcinia mangostana. Nat Prod Commun. 8 (12): 1733-1734.

Fukuyama Y, Minami H, Fujii H, Tajima M. 2002. Triterpenoids from Viburnum suspensum. PhytoChem 60 (8): 765-768.

Ganash M. 2019. Cytogenetic toxicity of Juniperus procera extract with silver nanoparticles against carcinoma colon $(\mathrm{CaCo}-2)$ cell line in vitro. Int J Pharmacol 15 (5): 576-585.

Ganeson S, bin Abdul Jamil MM, Ambar RB, Wahab RA. 2018. Influence of Artocarpus altilis fruit extract on cancer cell. 2018 9th IEEE Control and System Graduate Res. Colloquium (ICSGRC): 240-243.

García-Mendoza AJ, Sandoval-Gutiérrez D, Hernández Sandoval L, Puente R, Zamudio S, González-Elizondo M, Hernández-Martínez M. 2019. Agave salmiana. The IUCN Red List of Threatened Species. 
García-Mendoza AJ, Sandoval-Gutiérrez D, Hernández Sandoval L, Zamudio S. 2019. Agave americana. The IUCN Red List of Threatened Species.

García-Mendoza AJ, Sandoval-Gutiérrez D, Torres-García I., Linares J. 2019. Agave attenuata. The IUCN Red List of Threatened Species.

Geetha D, Rajeswari M, Jayashree I. 2013. Chemical profiling of Elaeocarpus serratus L. by GC-MS. Asian Pacific J Trop BioMed 3 (12): 985-987.

Gerlach SL, Rathinakumar R, Chakravarty G, Göransson U, Wimley WC, Darwin SP, Mondal D. 2010. Anticancer and chemosensitizing abilities of cycloviolacin $\mathrm{O} 2$ from Viola odorata and psyle cyclotides from Psychotria leptothyrsa. Biopolymers 94 (5): 61.

Ghalib RM, Hashim R, Sulaiman O, Mehdi SH, Anis Z, Rahman SZ, Ahamed BMK, Abdul Majid AMS. 2011. Phytochemical analysis, cytotoxic activity and constituents-activity relationships of the leaves of Cinnamomum iners (Reinw. Ex Blume-Lauraceae). Nat Prod Res $1-4$.

Gheraibia S, Belattar N, Abdel-Wahhab MA. 2020. HPLC analysis, antioxidant and cytotoxic activity of different extracts of Costus speciosus against HePG-2 cell lines. South Afr J Bot 131: 222-228.

Ghogue J-P. 2010. Acanthus montanus. The IUCN Red List of Threatened Species

Gleńsk M, Czapińska E, Woźniak M, Ceremuga I, Włodarczyk M, Terlecki G, Ziółkowski P, Seweryn E. 2017. Triterpenoid acids as important antiproliferative constituents of Eur. elderberry fruits. Nutr Cancer 69 (4): 643-651.

Goh MPY, Yasin H, Jama A, Ahmad N. 2018. Phytochemical and Biological activities of Litsea elliptica Blume. Med Aromatic Plants 7: 41.

Goulas V, Exarchou V, Troganis AN, Psomiadou E, Fotsis T, Briasoulis E, et al. Phytochemical in olive-leaf extracts and their antiproliferative activity against cancer and endothelial cells. Mol Nutr Food Res 53 (5):600-608.

Greenwell M, Rahman PKSM. 2015. Medicinal plants: their use in anticancer treatment. Int J Pharm Sci Res 6 (10): 4103-4112.

Habib FK, Ross M, KH Ho C, Lyons V, Chapman K. 2005. Serenoa

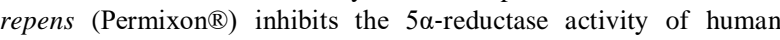
prostate cancer cell lines without interfering with PSA expression. Int J Cancer 11(2): 190-194.

Habib FK, Ross M, KH Ho C, Lyons V, Chapman K. 2005. Serenoa repens (Permixon $\left.{ }^{\circledR}\right)$ inhibits the $5 \alpha$-reductase activity of human prostate cancer cell lines without interfering with PSA expression. Int J Cancer 114 (2): 190-194.

Habsah M, Ali AM, Lajis NH, Sukari MA, Yap YH, Kikuzaki H. 2005 Antitumour promoting and cytotoxic constituents of Etlingera elatior. Malay J Med Sci 12: 6-12.

Hajiaghaalipour F, Kanthimathi MS, Sanusi J, Rajarajeswaran J. 2015. White tea (Camellia sinensis) inhibits proliferation of the colon cancer cell line, HT-29, activates caspases and protects DNA of normal cells against oxidative damage. Food Chem 169: 401-410.

Hakim EH, Asnizar, Yurnawilis, Aimi N, Kitajima M, Takayama H. 2002. Artoindonesianin $\mathrm{P}$, a new prenylated flavone with cytotoxic activity from Artocarpus lanceifolius. Fitoterapia 73 (7-8): 668-673.

Han B, BGCI, IUCN SSC Global Tree Specialist Group. 2019. Gleditsia sinensis. The IUCN Red List of Threatened Species.

Hanaoka A, Sakagami H, Konno K. 1989. Pine cone antitumor substances stimulate cytotoxic factor production in young mice, but not in aged or tumor-bearing mice. Showa Univ J Med Sci 1 (1.2): 57-63.

Handayani A. 2015. Diversity of Lamiaceae as potential drugs from Cibodas Botanic Gardens medicinal plant. Pros Sem Nas Masy Biodiv Indon 1 (6): 1324-1327. [Indonesian]

Harneti D, Supriadin A, Ulfah M, Safari A, Supratman U, Awang K, Hayashi H. 2014. Cytotoxic constituents from the bark of Aglaia eximia (Meliaceae). PhytoChem Lett 8: 28-31

Haryanti S, Widiyastuti Y, Rahmawati N. 2018. Cytotoxic and MMPs inhibitory activities of sappan wood (Caesalpinia sappan L.): Various extracts on 4T1 breast cancer cell line. Health Sci J Indones 9 (1): 5156.

Hemshekhar M, Sunitha K, Santhosh MS, Devaraja S, Kemparaju K, Vishwanath BS, Niranjana SR, Girish KS. 2011. An overview on genus Garcinia: phytochemical and therapeutical aspects. PhytoChem Rev 10 (3): 325-351.

Hernández HM, Cházaro M, Gómez-Hinostrosa C. 2017. Opuntia robusta (amended version of 2013 assessment). The IUCN Red List of Threatened Species.
Hidayat AT, Nurlelasari N, Abdullah FF, Harneti D, Maharani R, Haikal K, Supratman U, Azmi MN. 2018. A new lignan derivative, lasiocarpone, from the stembark of Chisocheton lasiocarpus (Meliaceae). Oriental J Chem 34 (4): 1956-1960.

Hilton-Taylor C. 1998. Catha edulis. The IUCN Red List of Threatened Species.

Ho C-L, Jie-Ping O, Liu Y-C, Hung C-P, Tsai M-C, Liao P-C, Wang EIC, Chen Y-L, Su Y-C. 2010. Compositions and in vitro anticancer activities of the leaf and fruit oils of Litsea cubeba from Taiwan. Nat Prod Commun 5 (4): 617-620.

Honari M, Shafabakhsh R, Reiter RJ, Mirzaei H, Asemi Z. 2019. Resveratrol is a promising agent for colorectal cancer prevention and treatment: Focus on molecular mechanisms. Cancer Cell Int 19 (1): 180-187.

Horgen FD, Edrada RA, de los Reyes G, Agcaoili F, Madulid DA, Wongpanich V, Angerhofer CK, Pezzuto JM. Soejarto DD, Farnsworth NR. 2001. Biological screening of rain forest plot trees from Palawan Island (Philippines). PhytoMed 8 (1): 71-81.

Hossan S, Rahman S, Al-Nahain A, Rahmatullah M. 2012. Rosmarinic acid: a review of its anticancer action. World J Pharmacy Pharm Sci 3 (9): 57-70.

Hosyar R, Mohagheh Z, Torabia N, Abolghasemi A. 2015. Antitumor activity of aqueous extract of Ziziphus jujube fruit in breast cancer: an in vitro and in vivo study. Asian Pac J Reproduct 4 (2): 116-122.

Hsieh T-J, Chang F-R, Chia Y-C, Chen C-Y, Chiu H-F, Wu Y-C. 2001. Cytotoxic constituents of the fruits of Cananga odorata. J Nat Prod 64 (5): 616-619.

Hsiung WY, Abdul Kadir H. 2011. Leea indica ethyl acetate fraction induces growth-inhibitory effect in various cancer cell lines and apoptosis in Ca Ski human cervical epidermoid carcinoma cells. Evidence-Based Complement Altern Med (2011): 1-13.

Huang S, Wang L-L, Xue N-N, Li C, Guo H-H, Ren T-K, Zhan Y, Li WB, Zhang J, Chen X-G, Han Y-X, Zhang J-L, Jiang -D. 2019. Chlorogenic acid effectively treats cancers through induction of cancer cell differentiation. Theranostics 9 (23): 6745-6763.

Huspa DHP. 2009. Senyawa antikanker dan insektisida dari genus Aglaia. Unpad Press, Bandung. [Indonesian]

Hutagaol RP, Harneti D, Hidayat AT, Nurlelasari N, Maharani R, Katja DG, Supratman U, Awang K, Shiono Y. 2020. (22E,24S)-24Propylcholest-5en-3 $\alpha$-acetate: A new steroid from the stembark Aglaia angustifolia (Miq.) (Meliaceae). Molbank 2020 (1): 1-6.

Hwang BY, Su B-N, Chai H, Mi Q, Kardono LBS, Afriastini JJ, Riswan S, Santarsiero BD, Mesecar AD, Wild R, Fairchild CR, Vite GD, Rose WC, Farnsworth NR, Cordell GA, Pezzuto JM, Swanson SM, Kinghorn AD. 2004. Silvestrol and episilvestrol, Potential anticancer rocaglate derivatives from Aglaia silvestris. J Organic Chem 69 (10) 3350-3358.

Ikuta A, Tomiyasu H, Morita Y, Yoshimura K. 2003. Ursane- and oleanane-type triterpenes from Ternstroemia gymnanthera callus tissues. J Nat Prod 66: 1051-1054

Imran M, Salehi B, Sharifi-Rad J, Aslam Gondal T, Saeed F, Imran A, Shahbaz M, Tsouh Fokou PV, Umair Arshad M, Khan H, Guerreiro SG, Martins N, Estevinho LM. 2019. Kaempferol: A key emphasis to its anticancer potential. Molecules 24 (12): 2277-2293.

Indonesian Ministry of Health. 2018. Hasil utama Riskesdas 2018. https://kesmas.kemkes.go.id [Indonesian]

International Agency for Research on Cancer (IARC). 2018. Press release World Health Organization: Latest global cancer data: cancer burden rises to 18.1 million new cases and 9.6 million cancer. https://www.who.int/cancer/PRGlobocanFinal.pdf

Iqbal J, Abbasi BA, Mahmood T, Kanwal S, Ali B, Shah SA, Khalil AT. 2017. Plant-derived anticancer agents: a green anticancer approach. Asian Pac J Trop Biomed 7 (12): 1129-1150.

Irudayaraj V. 2011. Diplazium esculentum. The IUCN Red List of Threatened Species.

Ismiyati N, Putri DDP, Kusumastuti SA, Febriansyah R. 2012. Antiproliferative effect of ethanolic extract Eugenia uniflora Lam. leaves on T47D Cells. Indonesian J Cancer Chemoprevention 3(2): 370-375.

IUCN SSC Global Tree Specialist Group \& BGCI. 2019. Cananga odorata. The IUCN Red List of Threatened Species.

IUCN SSC Global Tree Specialist Group \& BGCI. 2019. Dillenia serrata. The IUCN Red List of Threatened Species.

IUCN SSC Global Tree Specialist Group \& BGCI. 2019. Litsea mappacea. The IUCN Red List of Threatened Species. 
IUCN SSC Global Tree Specialist Group \& BGCI. 2019. Terminalia calamansanai. The IUCN Red List of Threatened Species.

IUCN SSC Global Tree Specialist Group \& BGCI. 2020. Coccoloba uvifera. The IUCN Red List of Threatened Species.

Jabit Md.L, Wahyuni FS, Khalid R, Israf DA, Shaari K, Lajis NH, Stansias J. 2009. Cytotoxic and nitric oxide inhibitory activities of methanol extracts of Garcinia species. Pharm Biol 47 (11): 10191026.

Jabit Md.L, Wahyuni FS, Khalid R, Israf DA, Shaari K, Lajis NH, Stansias J. 2009. Cytotoxic and nitric oxide inhibitory activities of methanol extracts of Garcinia species. Pharm Biol 47 (11): 10191026.

Jagetia GC, Baliga MS. 2006. Evaluation of anticancer activity of the alkaloid fraction of Alstonia scholaris (Sapthaparna) in vitro and in vivo. Phytotherapy Res 20 (2): 103-109.

Jalil J, Sabandar C, Ahmat N, Jamal J, Jantan I, Aladdin N-A, Muhammad K., Buang F, Mohamad H, Sahidin I. 2015. Inhibitory effect of triterpenoids from Dillenia serrata (Dilleniaceae) on Prostaglandin E2 production and quantitative HPLC analysis of its koetjapic acid and betulinic acid contents. Molecules 20 (2): 3206-3220.

Jang DS, Cuendet M, Pawlus AD, Kardono LBS, Kawanishi K, Farnsworth NR, Fong HHS, Pezzuto JM, Kinghorn AD. 2004. Potential cancer chemopreventive constituents of the leaves of Macaranga triloba. PhytoChem 65 (3): 345-350.

Jason K. Higa, Zhibin Liang, Philip G. Williams, Jun Panee. 2012 Phyllostachys edulis compounds inhibit palmitic acid-induced monocyte chemoattractant protein 1 (MCP-1) production. PLOS ONE 7 (9): e45082.

Jiang Z, Yaqiong P, Xiaobo Y, Suxia Z, Jun Q, Ning Z, Haiyan D, Qing S, Minliang K, Lee J. 2016. The paradigm-shifting idea and its practice: from traditional abortion Chinese medicine Murraya paniculata to safe and effective cancer metastatic chemopreventives. Oncotarget 7 (16): 21699-21712

Jin ML, Park SY, Kim YH, Park G, Lee SJ. 2014. Halofuginone induces the apoptosis of breast cancer cells and inhibits migration via downregulation of matrix metalloproteinase-9. Int. J. of Oncology 44(1): 309-318.

Jong JK, Bimal KG, Hyeun CS, Kyung JL, Ki SS, Young SC, Taek SY, Ye Ji L, Eun Hye K, Min C. 2012. Comparison of phenolic compounds content in indeciduous Quercus species. J Med Plants Res 6 (39): 5228-5239.

Juliawaty LD, Kitajima M, Takayama H, Achmad SA, Aimi N. 2000. A 6-substituted-5,6-dihydro-2-pyrone from Cryptocarya strictifolia. PhytoChem 54 (8): 989-993.

Jun NJ, Mosaddik A, Moon JY, Jang K-C, Lee D-S, Ahn KS, Cho SK. 2011. Cytotoxic activity of -caryophyllene oxide isolated from Jeju Guava (Psidium cattleianum Sabine) Leaf Rec Nat Prod 5 (3): 242246.

Kamurthy H, Dontha S. 2015. Phytochemical screening on Euphorbia milii red flowers - isolation of terpenoids, flavone and phenols. American J EthnoMed 2 (6): 322-332.

Kannabiran K, Khanna V. 2009. Anticancer-cytotoxic activity of saponins isolated from the leaves of Gymnema sylvestre and Eclipta prostrata on HeLa cells. Int J Green Pharm 3 (3): 227-229.

Kapp, K. 2015. Polyphenolic and Essential Oil Composition of Mentha and Their Antimicrobial Effect. [Disertation]. University of Helsinki. Finland.

Karimi E, Jaafarb HZE, Ghasemzadehb A. 2016. Chemical composition, antioxidant and anticancer potential of Labisia pumila variety alata under $\mathrm{CO}_{2}$ enrichment. NJAS Wageningen J Life Sci 78: 85-91.

Kaššák P. 2012. Secondary metabolites of the choosen genus Iris species. Acta Universitatis Agriculturae et Silviculturae Mendelianae Brunensis 60 (8): 269-280

Kavak S. 2014. Iris pseudacorus. The IUCN Red List of Threatened Species.

Khela S, Wilson B. 2018. Laurus nobilis. The IUCN Red List of Threatened Species.

Kiem PV, Thu VK, Yen PH, Nhiem NX, Tung NH, Cuong NX, Minh CV, Huong HT, Hyun JH, Kang HK, Kim YH. 2009. New triterpenoid saponins from Glochidion eriocarpum and their cytotoxic activity. Chem Pharm Bull 57: 102-105.

Kikuchi T, Akazawa H, Tabata K, Manosrol A, Manosrol J, Suzuki T, Akihisa T. 2011. 3-O-(E)-p-coumaroyl tormentic acid from Eriobotrya japonica leaves induces caspase-dependent apoptotic cell death in human leukemia cell line. Chem Pharm Bull 59 (3) 378-381.
Kikuchi T, Nihei M, Nagai H, Fukushi H, Tabata K, Suzuki T, Akihisa T. 2010. Albanol A from the root bark of Morus alba L. induces apoptotic cell death in HL60 human leukemia cell line. Chem Pharm. Bull 58 (4): 568-571.

Kim E-S, Jeong C-S, Moon A. 2012. Genipin, a constituent of Gardenia jasminoides Ellis, inducesapoptosis and inhibits invasion in MDAMB-231 breast cancer cells. Oncology Rep 27: 567-572.

Kim S, Chin Y-W, Su B-N, Riswan S, Kardono LBS, Afriastini JJ, Chai H, Farnsworth NR, Cordell GA, Swanson SM, Kinghorn AD. 2006. Cytotoxic flavaglines and bisamides from Aglaia edulis. J Nat Prod 69 (12): 1769-1775

Kirollos FN, Elhawary SS, Salama OM, Elkhawas YA. 2019. LC-ESIMS/MS and cytotoxic activity of three Pistacia species. Nat Prod Res. 33 (12): 1747-1750.

Ko H-H, Lu Y-H, Yang S-Z, Won S-J, Lin C-N. 2005. Cytotoxic prenylflavonoids from Artocarpus elasticus. J Nat Prod 68 (11): 1692-1695.

Kornienko A, Evidente A. 2008. Chemical, biological, and medicinal potential of narciclasine and its congeners. Chem Rev 108 (6): 19822014.

Kosasih K, Sumaryono W, Supriono A, Mudhakir D. 2019. Cytotoxicity of ethyl acetate extract of cantigi (Vaccinium varingiaefolium (Blume) Miq. young leaves on Artemia salina L. larvae, MCF7, T47D, and vero cell lines. J Pharmacogn PhytoChem 8 (4): 24-33.

Krajarng A, Chulasiri M, Watanapokasin R. 2017. Etlingera elatior extract promotes cell death in B16 melanoma cells via downregulation of ERK and Akt signaling pathways. BMC Complement Altern Med 17: 415.

Kubatka P, Kello M, Kajo K, Samec M, Jasek K, Vybohova D, Uramova S, Liskova A, Sadlonova V, Koklesova L, Murin R, Adamkov M, Smejkal K, Svajdlenka E, Solar P, Samuel SM, Kassayova M, Kwon TK, Zubor P, Mojzis J. 2020. Chemopreventive and therapeutic efficacy of Cinnamomum zeylanicum L. bark in experimental breast carcinoma: mechanistic in vivo and in vitro analyses. Molecules 25 (6): 1399-1430.

Kuete V, Voukeng IK, Tsobou R, Mbaveng AT, Wiench B, Beng VP, Efferth T. 2013. Cytotoxicity of Elaoephorbia drupifera and other Cameroonian medicinal plants against drug sensitive and multidrug resistant cancer cells. BMC Complement Altern Med 13 (1): 250-257.

Kumar Y, Periyasamy L. 2016. GC-MS analysis and in vitro cytotoxic studies of Bixa orellana seed extract against cancer cell line. Int J Pharm Pharm Sci 8 (1): 408-413.

Kuo P-L, Hsu Y-L, Sung S-C, Ni W-C, Lin T-C, Lin C-C. 2007. Induction of apoptosis in human breast adenocarcinoma MCF7 cells by pterocarnin A from the bark of Pterocarya stenoptera via the Fasmediated pathway: Anti-Cancer Drugs 18 (5): 555-562.

Kurniadewi F, Juliawaty LD, Syah YM, Achmad SA, Hakim EH, Koyama K, Kinoshita K, Takahashi K. 2010. Phenolic compounds from Cryptocarya konishii: Their cytotoxic and tyrosine kinase inhibitory properties. J Nat Med 64 (2): 121-125.

Kusari S, Zühlke S, Spiteller M. 2011. Chemometric evaluation of the anti-cancer pro-drug podophyllotoxin and Potential therapeutic analogues in Juniperus and Podophyllum species. PhytoChem Anal 22 (2): 128-143

Kutoi CJ, Yen KH, Seruji NMU. 2012. Pharmacol. evaluation of Litsea garciae (Lauraceae). 2012 IEEE Business, Engineering and Industrial Applications Colloquium (BEIAC): 31-33.

Kwon H-J, Lee E-W, Hong Y-K, Yun H-J, Kim B-W. 2010. Widdrol from Juniperus chinensis induces apoptosis in human colon adenocarcinoma HT-29 Cells. Biotechnol Bioprocess Eng 15 (1): 167-172.

Lai HY, Lim YY, Kim KH. 2010. Blechnum Orientale Linn - a fern with Potential as antioxidant, anticancer and antibacterial agent. BMC Complement Altern Med 10: 15-22.

Lai W-C, Tsui Y-T, Singab A, El-Shazly M, Du Y-C, Hwang T-L, Wu CC, Yen M-H, Lee C-K, Hou M-F, Wu Y-C, Chang F-R. 2013. PhytoSERM constitutes from Flemingia macrophylla. Int J Mol Sci 14 (8): $15578-15594$

Lai Y, Liu H, BGCI \& IUCN SSC Global Tree Specialist Group. 2019. Viburnum odoratissimum. The IUCN Red List of Threatened Species.

Lansdown RV, Beentje HJ. 2017. Eclipta prostrata (amended version of 2017 assessment). The IUCN Red List of Threatened Species.

Lansdown RV. 2014. Acorus calamus. The IUCN Red List of Threatened Species.

Lansdown RV. 2018. Cyperus alternifolius. The IUCN Red List of Threatened Species. 
Lansdown RV. 2018. Equisetum ramosissimum. The IUCN Red List of Threatened Species.

Lansdown RV. 2019. Centella asiatica. The IUCN Red List of Threatened Species.

Lee SK, Cui B, Mehta RR, Kinghorn AD, Pezzuto JM. 1998. Cytostatic mechanism and antitumor Potential of novel $1 \mathrm{H}$ cyclopenta[b]benzofuran lignans isolated from Aglaia elliptica. Chemico-Biol Interact 115 (3): 215-228.

Lei T, Li Y, Li D-M, Liu G-M, Liu J-K, Wang F. 2011. A novel phenolic compound from Pinus yunnanensis. J Asian Nat Pro. Res 13 (5): 425 429.

Li J-Z, Qing C, Chen C-X, Hao X-J, Liu H-Y. 2009. Cytotoxicity of cardenolides and cardenolide glycosides from Asclepias curassavica. Bioorganic Med Chem. Lett 19 (7): 1956-1959.

Li K-K, Xu F, Li S-S, Cao G-Y, Gong X-J. 2019. Cytotoxic epimeric ginsenosides from the flower buds of Panax ginseng. Steroids 143: 1 5.

Li P-H, Chiu Y-P, Shih C-C, Wen Z-H, Ibeto LK, Huang S-H, Chiu CC, Ma D-L, Leung C-H, Chang Y-N, Wang H-MD. 2016. Biofunctional activities of Equisetum ramosissimum extract: protective effects against oxidation, melanoma, and melanogenesis. Oxidative Med Cell Longevity 2016: 1-9.

Li W, Chiu L, Lam W, Wong W, Chan Y, Ho Y, Wong E, Wong Y, Ooi V. 2007. Ethyl acetate extract of Chinese Med. herb Sarcandra glabra induces growth inhibition on human leukemic HL-60 cells, associated with cell cycle arrest and up-regulation of pro-apoptotic Bax/Bcl-2 ratio. Oncology Rep 17: 425-431.

Li X, Li Y, Luo J, Zhou Z, Xue G, Kong L. 2017. New phloroglucinol derivatives from the whole plant of Hypericum uralum. Fitoterapia 123: 59-64.

Liao J, Wu F, Lin W, Huang Z. 2018. Taraxerol exerts active anticancer effects via induction of apoptosis and inhibition of Nf-kB signalling pathway in human middle ear epithelial cholesteatoma cells. Trop J Pharm Res 17 (6): 1011-1017.

Lichota A, Gwodzdzinski K. 2018. Anticancer activity of natural compounds from plant and marine environment. Int J Mol Sci 19 3533-3570

Lim SW, Ting KN, Bradshaw TD, Zeenathul NA, Wiart C, Khoo TJ, Lim KH, Loh HS. 2011. Acalypha wilkesiana extracts induce apoptosis by causing single strand and double strand DNA breaks. J Ethno Pharmacol 138 (2): 616-623.

Lin A-S, Lin C-R, Du Y-C, Lübken T, Chiang M, Chen I.-H, Wu C-C, Hwang T-L, Chen S-L, Yen M-H, Chang F-R, Wu Y-C. 2009. Acasiane A and B and Farnesirane A and B, diterpene derivatives from the roots of Acacia farnesiana. Plant Med 75 (03): 256-261.

Lin R-J, Lo W-L, Wang Y-D, Chen C-Y. 2008. A novel cytotoxic monoterpenoid from the leaves of Cinnamomum subavenium. Nat Prod Res 22 (12): 1055-1059.

Lissoni P, Rovelli F, Brivio F, Zago R, Colciago M, Messina G, Mora A, Porro G. A randomized study of chemotherapy versus biochemotherapy with chemotherapy plus Aloe arborescens in patients with metastatic cancer. In Vivo 23: 171-175.

Loizzo MR, Tundis R, Menichini F, Saab AM, Statti GA, Menichini F. 2008. Antiproliferative effects of essential oils and their major constituents in human renal adenocarcinoma and amelanotic melanoma cells: essential oils cytotoxicity. Cell Proliferation 41 (6): 1002-1012.

Lu B, Lianliang L, Xiaowei Z, Xiaoqin W, Ying Z. 2012. Anti-tumor activity of triterpenoid-rich extract from bamboo shavings (Caulis bamfusae in Taeniam). African J Biotechnol 9 (38): 6430-6436.

Madunić J, Matulić M, Friščić M, Pilepić KH. 2016. Evaluation of the cytotoxic activity of Hypericum spp. on human glioblastoma A1235 and breast cancer MDA MB-231 cells. J Environ Sci Health 51 (13): 1157-1163.

Magadula JJ, Erasto P. 2009. Bioactive natural product derived from the East African flora. Nat Prod Rep 26 (12): 1535-1554.

Mah SH, Ee GCL, Teh SS, Rahmani M, Lim YM, Go R. 2012. Phylattrin, a new cytotoxic xanthone from Calophyllum soulattri. Molecules 17: 8303-8311

Maiz-Tome L. 2016. Achillea millefolium. The IUCN Red List of Threatened Species.

Mallavadhani UV, Panda AK, Rao YR. 1998. Review article number 134 Pharmacology and chemotaxonomy of Diospyros. PhytoChem 49 (4): 901-951.
Mangal M, Sagar P, Singh H, Raghava GPS, Agarwal SM. 2013. NPACT: naturally occurring plant-based anti-cancer compound activity-target database. Nucleic Acids Res. 41: 1124-1129.

Manosroi A, Sainakham M, Chankhampan C, Manosroi W, Manosroi J. 2016. In vitro anti-cancer activities of Job's tears (Coix lachryma-jobi Linn.) extracts on human colon adenocarcinoma. Saudi J Biol Sci 23: 248-256.

Maoka T, Mochida K, Kozuka M, Ito Y, Fujiwara Y, Hashimoto K, Enjo F, Ogata M, Nobukuni Y, Tokuda H, Nishino H. 2001. Cancer chemopreventive activity of carotenoids in the fruits of red paprika Capsicum annuum L. Cancer Lett 172: 103-109.

Martínez Richart AI. 2019. Aloe arborescens. The IUCN Red List of Threatened Species.

Masondo NA, Finnie JF, Van Staden J. 2014. Pharmacological Potential and conservation prospect of the genus Eucomis (Hyacinthaceae) endemic to southern Africa. J Ethno Pharmacol 151: 44-53.

Matloub AA, Mohammed RS, Souda SSE, El-Hallouty SM, Gomaa EZ, Hassan AA. 2018. Phytochemical and biological studies on Enterolobium contortisiliquum (Vell.) Morong Pericarps. J Mat Environ Sci 9 (10): 2768-2778.

Matsunaga H, Katano M, Yamamoto H, Fujito H, Mori M, Takata K. 1990. Cytotoxic activity of polyacetylene compounds in Panax ginseng C. A. Meyer. Chem Pharm Bull 38 (12): 3480-3482.

Mbaveng AT, Kuete V, Mapunya BM, Beng VP, Nkengfack AE, Meyer JJM, Lall N. 2011. Evaluation of four Cameroonian medicinal plants for anticancer, antigonorrheal and antireverse transcriptase activities. Environ Toxicol Pharmacol 1-17.

McDougal OM, Heenan PB, Perry NB, van Klink JW. 2018. Chemotaxonomy of kōwhai: Leaf and seed flavonoids of New Zealand Sophora species. N Z J Bot 56 (3): 227-236.

Meiyanto E, Rahmi F, Riyanto S. 2007. Kulit batang cangkring (Erythrina fusca Lour) terhadap sel HeLa. Majalah Obat Tradisional 11 (41): 111. [Indonesian]

Mena-Rejon G, Caamal-Fuentes E, Cantillo-Ciau Z, Cedillo-Rivera R, Flores-Guido J, Moo-Puc R. 2009. In vitro cytotoxic activity of nine plants used in Mayan traditional medicine. J Ethno Pharmacol 121 (3): $462-465$.

Menichini F, Tundis R, Loizzo MR, Monesi M, Provenzano E, de Cindio B, Menichini F. 2010. In vitro photo-induced cytotoxic activity of Citrus bergamia and C. medica L. cv. Diamante peel essential oils and identified active coumarins. Pharm Biol 48 (9): 1059-1065.

Mohamad K, Sevenet T, Dumontet V, Pais M, Vantri M, Hadi H, Awang K, Martin M. 1999. Dammarane triterpenes and pregnane steroids from Aglaia lawii and A. tomentosa. Phyto Chem 51 (8): 1031-1037.

Moirangthem DS, Talukdar NC, Bora U, Kasoju N, Das RK. 2013. Differential effects of Oroxylum indicum bark extracts: antioxidant, antimicrobial, cytotoxic and apoptotic study. Cytotechnology 65 (1): 83-95.

Monks NR, Bordignon SAL, Ferraz A, Machado KR, Faria DH, Lopes RM, Mondin CA, Souza ICC, Lima MFS, da Rocha AB, Schwartsmann G. 2002. Anti-tumour screening of Brazilian plants. Pharm Biol 40 (8): 603-616.

Mori ALB, Kalschne DL, Ferrão MAG, Fonseca AFA, da Ferrão RG, enassi M de T. 2016. Diterpenes in Coffea canephora. J Food Compos Anal (52): 52-57.

Mouhid L, Gómez de Cedrón M, Vargas T, García-Carrascosa E, Herranz N, García-Risco M, Reglero G, Fornari T, Ramírez de Molina A. 2018. Identification of antitumoral agents against human pancreatic cancer cells from Asteraceae and Lamiaceae plant extracts. BMC Complement Altern Med 18 (1): 254-264.

Muhaimin M, Nurlaeni Y. 2018. Exudate-producing plants collection of Cibodas Botanic Gardens and its uses. Pros Sem Nas Masy Biodiv Indon 4: 151-157. [Indonesian]

Muhaimin M. 2016. Taxus sumatrana Miq. de Laub. Obat antikanker masa depan. Warta Kebun Raya 14 (1): 11-20. [Indonesian]

Muhammed RA, Hassawi DS, Ibaheem NK. 2018. Cytotoxic activity of Taraxacum officinale ethanolic plant extract against human breast cancer (MCF7) cells and human hepatic (WRL-68) cells. Iraqi J Cancer Med Gen 11(1): 16-21.

Mukherjee A, Sikdar S, Bishayee K, Boujedaini N, Khuda-Bukhsh AR. 2014. Flavonol isolated from ethanolic leaf extract of Thuja occidentalis arrests the cell cycle at G2-M and induces ROSindependent apoptosis in A549 cells, targeting nuclear DNA. Cell Prolif 47 (1): 56-71 
Myint PP, Dao TTP, Kim YS. 2019. Anticancer activity of Smallanthus sonchifolius methanol extract against human hepatocellular carcinoma cells. Molecules 24 (17): 3054-3064

N'gaman KCC, Kabran GRM, Kadja BA, Mamyrbékova-Békro JA, Lecouvey M, Sainte-Cathérine O, Sommerer N, Verbaere A, Meudec E, Békro YA. 2014. ULPC-MS/MS phenolic quantification and in vitro anticancer Potential of Gmelina arborea Roxb. (Verbenaceae). Der Chem Sin 5 (6): 13-17.

Nadhifah A, Khujjah M, Vitara PE, Noviady I. 2018. Bryophytes in Cibodas Botanic Gardens: Diversity and potential uses. Biosaintifika 10 (2): 455-463

Nagata T, Fujino Y, Toume K, Xiao Long L, Yamaguchi T, Okumura T, Komatsu K, Shimada Y. 2016. Anti-cancer effect in volatile components of hiba essential oil (Thujopsis dolabrata). J Clin Exp Pharmacol 6 (4): 214-218.

Najihah, Sutoyo S, Ismono, Mitarlis. 2018. Toxicity assay of phenolic compound isolated from the dichloromethane extract of silver fern (Pityrogramma calomelanos). Adv Eng Res 171: 63-66.

Nassar D, Aisha AFA, Al Suede FSR, Abdul Majid AS, Abdul Majid AMS. 2012. In vitro antimetastatic activity of koetjapic acid against breast cancer cells. Biol Pharm Bull 35 (4): 503-508.

Nath R, Roy S, De B, Choudhury MD. 2013. Anticancer and antioxidant activity of Croton: A review. Int J Pharm Pharm Sci 5 (2): 63-70.

Newell AMB, Yousef GG, Lila MA, Ramírez-Mares MV, Gonzalez de Mejia E. 2010. Comparative in vitro bioactivities of tea extracts from six species of Ardisia and their effect on growth inhibition of HepG2 cells. J Ethno Pharmacol 130 (3): 536-544.

Ngoc TM, Nhiem NX, Khoi NM, Son DC, Hung TV, Van Kiem P. 2014 A new coumarin and cytotoxic activities of constituents from Cinnamomum cassia. Nat Prod Commun 9 (4): 487-488.

Nguyen PH, Le TVT, Thuong PT, Dao TT, Ndinteh DT, Mbafor JT, Kang KW, Oh WK. 2009. Cytotoxic and PTP1B inhibitory activities from Erythrina abyssinica. Bioorganic Med Chem Lett 19 (23): 67456749.

Nguyen TT, Truong BN, Doan Thi Mai H, Litaudon M, Nguyen VH, Do Thi T, Chau VM, Pham VC. 2017. Cytotoxic dammarane-type triterpenoids from the leaves of Viburnum sambucinum. Bioorganic Med Chem Lett 27 (8): 1665-1669.

Ni G, Yang H-Z, Fu N-J, Zhang L-L, Wang M-C, Chen J, Zhang C-L, Li Y, Chen X-G, Chen R-Y, Yu D-Q. 2015. Cytotoxic taccalonolides and withanolides from Tacca chantrieri. Plant Med 81 (03): 247-256.

Nikmatullah M, Junaedi DI, Witono JR, Hendrian R. 2019. Inventory study of plants collection in the Medicinal Thematic Garden, Cibodas Botanic Gardens. IOP Conf Ser: Earth Environ Sci 399.

Nisa S, Bibi Y, Zia M, Waheed A, Chaudhary MF. 2013. Anticancer investigations on Carissa opaca and Toona ciliata extracts against human breast carcinoma cell line. Pakistan J Pharm Sci 26 (5): 1009 1012.

Nordin ML, Abdul Kadir A, Zakaria ZA, Abdullah R, Abdullah MNH. 2018. In vitro investigation of cytotoxic and antioxidative activities of Ardisia crispa against breast cancer cell lines, MCF-7 and MDA-MB231. BMC Complement Altern Med 18: 87-96.

Nordin ML, Abdul Kadir A, Zakaria ZA, Othman F, Abdullah R, Abdullah MNH. 2017. Cytotoxicity and apoptosis induction of Ardisia crispa and its solvent partitions against Mus musculus mammary carcinoma cell line (4T1). Evidence-Based Complement Altern Med 2017: 1-10.

Nordin ML, Othman AA, Kadir AA, Shaari R, Osman AY, Mohamed M. 2019. Antibacterial and cytotoxic activities of the Syzygium polyanthum leaf extract from Malaysia, Veterinary World, 12(2):236 242.

Normasiwi S, Surya MI. 2016. The potential fruit crop of Cibodas Botanic Gardens. Biosaintika: J Biol Bio Educ 8 (2): 206-213.

Nugroho AE, Hermawan A, Putri DDP, Novika A, Meiyanto E. 2013. Combinational effects of hexane insoluble fraction of Ficus septica Burm. F. and doxorubicin chemotherapy on T-47D breast cancer cells. Asian Pac J Trop BioMed 3(4): 297-302.

Obaid HH, Barakat NT, Abdul-Halim AG, Abood ZH, Sagban LH. 2012. Cytotoxic effect of saponins extracted from Yucca on human breast cell line (HBL-100) in vitro. Iraqi J Biotechnol 16 (3): 223-229.

Oldfield S. 2018. Schima wallichii. The IUCN Red List of Threatened Species.

Oldfield S. 2020. Croton argyratus. The IUCN Red List of Threatened Species.

Oldfield S. 2020. Viburnum sambucinum. The IUCN Red List of Threatened Specie.s
Othman SNAM, Arker SD, Talukdar AD, Ningthoujan SS, Khamis S, Basar N. 2014. Chemical constituents and antibacterial activitiy of Phaleria macrocarpa (scheff.) Boerl. Iraqi J Biotechnol 16 (3): 223229.

Pan L, Terrazas C, Acuña UM, Ninh TN, Chai H, Carcache de Blanco EJ, Soejarto DD, Satoskar AR, Kinghorn AD. 2014. Bioactive indole alkaloids isolated from Alstonia angustifolia. Phyto Chem Lett 1-6.

Pandey BR, Shrestha A, Sharma N, Shrestha BG. 2019. Evaluation of phytochemical, antimicrobial, antioxidant activity and cytotoxic Potentials of Agave americana. Nepal J Biotechnol 7 (1): 30-38.

Pannell CM. 1998. Aglaia angustifolia. The IUCN Red List of Threatened Species.

Pannell CM. 1998. Aglaia argentea. The IUCN Red List of Threatened Species.

Pannell CM. 1998. Aglaia edulis. The IUCN Red List of Threatened Species.

Pannell CM. 1998. Aglaia elliptica. The IUCN Red List of Threatened Species.

Pannell CM. 1998. Aglaia forbesii. The IUCN Red List of Threatened Species.

Pannell CM. 1998. Aglaia lawii. The IUCN Red List of Threatened Species.

Pannell CM. 1998. Aglaia odorata. The IUCN Red List of Threatened Species.

Pannell CM. 1998. Aglaia odoratissima. The IUCN Red List of Threatened Species.

Pannell CM. 1998. Aglaia silvestris. The IUCN Red List of Threatened Species.

Pannell CM. 1998. Aglaia tomentosa. The IUCN Red List of Threatened Species.

Participants of the FFI/IUCN SSC Central Asian regional tree Red Listing workshop, Bishkek, Kyrgyzstan (11-13 July 2006). 2007. Ziziphus jujuba. The IUCN Red List of Threatened Species.

Patel RM, Patel SK. 2011. Cytotoxic activity of methanolic extract of Artocarpus heterophyllus against A549, Hela and MCF7 cell lines. J Appl Pharm Sci 1 (7): 167-171.

Patel S. 2012. Yucca: A medicinaly significant genus with manifold therapeutic attributes. Nat Prod Bioprospecting 2 (6): 231-234.

Pecera T, Gazzola MV, Mucignat C, Parolin C, Vecchia FD, Cavaggioni A, Basso G, Diaspro A, Salvato B, Carli M, Palu G. 2020. Aloeemodin is a new type of anticancer agent with selective activity against neuroectodermal tumors. Cancer Res 60: 2800-2804.

Peng W-W, Zeng G-Z, Songa W-W, Tan N-H. 2013. A new cytotoxic carbazole alkaloid and two new other alkaloids from Clausena excavate. ChemBiodivers 10: 1317-1321.

Perera LMS, Veloz AIR, GoisRuiz ALT, Foglio MA, de Carvalho JE. 2019. In vitro and in vivo antiproliferative activity of extracts and fractions of leaves and stem from Tabebuia hypoleuca (C. Wright) Urb. Drug Discov 13:10-21.

Péresse T, Jézéquel G, Allard P-M, Pham V-C, Huong DTM, Blanchard $\mathrm{F}$, Bignon $\mathrm{J}$, Lévaique $\mathrm{H}$, Wolfender $\mathrm{J}$-L, Litaudon $\mathrm{M}$, Roussi $\mathrm{F}$. 2017. Cytotoxic prenylated stilbenes isolated from Macaranga tanarius. J Nat Prod 80 (10): 2684-2691.

Perng D-S, Tsai Y-H, Cherng J, Kuo C-W, Shiao C-C, Cherng J-M. 2016. Discovery of a novel anti-cancer agent targeting both topoisomerase I and II in hepatocellular carcinoma Hep3B cells In vitro and in vivo: Cinnamomum verum component 2-methoxycinnamaldehyde. J Drug Targeting 24 (7): 624-634.

Pham VC, Ma J, Thomas SJ, Xu Z, Hecht SM. 2005. Alkaloids from Alangium javanicum and Alangium grisolleoides that mediate $\mathrm{Cu} 2+-$ dependent DNA strand scission. J Nat Prod 68 (8): 1147-1152.

Poma P, Labbozzetta M, McCubrey JA, Ramarosandratana AV, Sajeva M, Zito P, Notarbartolo M. 2019. Antitumor mechanism of the essential oils from two succulent plants in multidrug resistance leukemia cell. Pharm 12 (3): 124-139.

Ponraj T, Kannan S. 2014. Anti-cancer activity of (Phyllanthus emblica) plant extract induced apoptosis and targeting survivin in MCF-7 Carcinoma cells. J Int J Recent Sci Re. 5 (11): 2123-2127.

Poulsen AD, Olander SB. 2019. Etlingera elatior. The IUCN Red List of Threatened Species.

Pratiwi DR, Bintang M, Simanjuntak P. 2014. Lelutung tokak (Tabernaemontana macrocarpa Jack.) sebagai sumber zat bioaktif antioksidan dan antikanker. Jurnal Ilmu Kefarmasian Indonesia 12 (2): 267-272. [Indonesian]

Proboningrat A, Fadholly A, Iskandar RPD, Achmad AB, Rantam FA, Sudjarwo SA. 2019. The potency of chitosan-based Pinus merkusii 
bark extract nanoparticles as anti-cancer on HeLa cell lines. Vet World 12 (10): 1616-1623.

Promraksa B, Daduang J, Khampitak T, Tavichakorntrakool R, Koraneekit A, Palasap A, Tangrassameeprasert R, Boonsiri P. 2015. Anticancer Potential of Cratoxylum formosum subsp. pruniflorum (Kurz.) Gogel extracts against cervical cancer cell lines. Asian Pac J Cancer Prev 16 (14): 6117-6121.

Purbowati R, Ersam T. 2019. Exploration of phenolic compound from the stem bark of Garcinia latissima Miq. Jurnal Sains dan Seni ITS 8 (2): 2337-3520. [Indonesian]

Putra WE, Rifa'i M. 2019. Immunomodulatory activities of Sambucus javanica extracts in DMBA exposed BALB/c mouse. Adv Pharm Bull 9 (4): 619-623.

Qi Y-Y, Su J, Zhang Z-J, Li L-W, Fan M, Zhu Y, Zhao Q-S. 2018. Two new anti-proliferative c18 -norditerpenes from the roots of Podocarpus macrophyllus. Chem Biodivers 15 (4).

Rabehevitra AD. 2019. Kalanchoe beharensis. The IUCN Red List of Threatened Species.

Rahmat A, Kumar V, Fong L-M, Endrini S, Sani HA. 2003. Determination of total antioxidant activity in three types of local vegetables shoots and the cytotoxic effect of their ethanolic extracts against different cancer cell lines. Asia Pac J Clin Nutr 12 (3): 292295

Rajkapoor B, Jayakar B, Murugesh N, Sakthisekaran D. 2006 Chemoprevention and cytotoxic effect of Bauhinia variegata against $\mathrm{N}$-nitrosodiethylamine induced liver tumors and human cancer cell lines. J Ethno Pharmacol 104 (3): 407-409.

Rajkumar V, Gunjan G, Kumar RA, Lazar M. 2009. Evaluation of cytotoxic Potential of Acorus calamus rhizome. Ethnobot Leaflets 13: 832-39.

Raman RP, Parthiban S, Srinithya B, Kumar VV, Anthony SP, Sivasubramanian A, Muthuraman MS. 2015. Biogenic silver nanoparticles synthesis using the extract of the medicinal plant Clerodendron serratum and its in vitro antiproliferative activity. Mater Lett 1-9.

Rasul A, Millimouno FM, Ali Eltayb W, Ali M, Li J, Li X. 2013. Pinocembrin: a novel natural compound with versatile pharmacological and biological activities. BioMed Res Int 2013: 1-9.

Razanajatovo H. 2020. Euphorbia milii. The IUCN Red List of Threatened Species.

Ren Y, Lantvit DD, Carcache de Blanco EJ, Kardono LBS, Riswan S, Chai H, Cottrell CE, Farnsworth NR, Swanson SM, Ding Y, Li X-C Marais JPJ, Ferreira D, Kinghorn AD. 2010. Proteasome-inhibitory and cytotoxic constituents of Garcinia lateriflora: absolute configuration of caged xanthones. Tetrahedron 66 (29): 5311-5320.

Rezadoost MH, Kumleh HH, Ghasempour A. 2019. Cytotoxicity and apoptosis induction in breast cancer, skin cancer and glioblastoma cells by plant extracts. Mol Biol Rep 46 (5): 5131-5142.

Rivers MC, Barstow M, Mark J. 2017. Aleurites moluccanus. The IUCN Red List of Threatened Species.

Rivers MC, Wheeler L. 2018. Camellia sinensis. The IUCN Red List of Threatened Species.

Rizwan K, Zubair M, Rasool N, Riaz M, Zia-Ul-Haq M, de Feo V. 2012. Phytochemical and biological studies of Agave attenuate. Int J Mo Sci 13: 6440-6451

Roslen NA, Alewi NAM, Ahamada H, Rasad MSBA. 2014. Cytotoxicity screening of Melastoma malabathricum extracts on human breas cancer cell lines in vitro. Asian Pac J Trop BioMed 4 (7): 545-548

Rowe H, Puente R. 2020. Yисca glauca. The IUCN Red List of Threatened Species.

Salama ZA, Aboul-Enein AM, Gaafar AA, Asker MS, Aly FH, Ahmed HA. 2020. In-vitro antioxidant, antimicrobial and anticancer activities of banana leaves (Musa acuminata) and olive leaves (Olea europae L.) as by-products. Res J Pharm Technol 13 (2): 687-696.

Saleem H, Htar TT, Naidu R, Ahmad I, Zengin G, Ahmad M, Ahemad N. 2019. Investigations into the therapeutic effects of aerial and stem parts of Buxus papillosa C.K. Schneid.: in vitro chemical, biological and toxicological perspectives. Pharm Biomed Anal 166: 128-138.

Sankar R, Maheswari R, Karthik S, Shivashangari KS, Ravikumar V. 2014. Anticancer activity of Ficus religiosa engineered copper oxide nanoparticles. Mater Sci Eng C 44: 234-239.

Santos D de A, Alves PB, Costa EV, Franco CRP, Nepel A, Barison A. 2014. Volatile constituents of Aristolochia trilobata L. (Aristolochiaceae): a rich source of sulcatyl acetate. Química Nova 37 (6): 977-981
Santos-Zea L, Rosas-Pérez AM, Leal-Díaz AM, Gutiérrez-Uribe JA. 2016. Variability in saponin content, cancer antiproliferative activity and physicochemical properties of concentrated agave sap: saponin variability in agave sap. J Food Sci 81 (8): 1-7.

Sari RK, Syafii W, Achmadi SS, Hanafi M. 2012. Aktivitas antikanker dan kandungan kimia ekstrak kayu teras suren. Jurnal Ilmu dan Teknologi Kayu Tropis 10 (1): 1-11. [Indonesian]

Saroyobudiyono H, Aisyah S. 2006. A trimer resveratrol compound from Shorea platyclados Sloot trunk leather (Dipterocarpaceae). Jurnal Penelitian Sains dan Teknologi 7 (1): 11-16. [Indonesian]

Satyal P, Paudel P, Poudel A, Dosoky NS, Pokharel KK, Setzer WN. 2013. Bioactivities and compositional analyses of cinnamomum essential oils from Nepal: C. camphora, C. tamala, and $C$. glaucescens. Nat Prod Commun 8 (12): 1777-1784.

Seangphakdee P, Pompimon W, Meepowpan P, Panthong A, Chiranthanut N, Banjerdpongchai R, Wudtiwai B, Nuntasaen N, Pitchuanchom S. 2013. Anti-inflammatory and anticancer activities of (-)-zeylenol from stems of Uvaria grandiflora. Sci Asia 39 (6): 610-614.

Sebola TE, Uche-Okereafor NC, Tapfuma KI, Mekuto L, Green E, Mavumengwana V. 2019. Evaluating antibacterial and anticancer activity of crude extracts of bacterial endophytes from Crinum macowanii Baker bulbs. MicroBiol Open 8 (12): 1-10.

Seca AML, Pinto DCGA. 2017. Plant secondary metabolites as anticancer agents: successes in clinical trials and therapeutic application. Int $\mathbf{J}$ Mol Sci 19 (1): 263

Selim, Y, El-Sharkawy E, Abd El-Azim MHM. 2020. New cytotoxic flavonoids from aerial parts of Platycladus orientalis L. Nat Prod Res 34 (12): 1763-1771.

Semwal DK, Badoni R, Semwal R, Kothiyal SK, Singh GJP, Rawat U. 2010. The genus Stephania (Menispermaceae): chemical and pharmacological perspectives. J Ethnopharmacol 132 (2): 369-383.

Seo Y, Hoch J, Abdel-Kader M, Malone S, Derveld I, Adams H, Werkhoven MCM, Wisse JH, Mamber SW, Dalton JM, Kingston DGI. 2002. Bioactive saponins from Acacia tenuifolia from the Suriname rainforest 1. J Nat Prod 65 (2): 170-174.

Serra AT, Poejo J, Matias AA, Bronze MR, Duarte CMM. 2013. Evaluation of Opuntia spp. derived product as antiproliferative agents in human colon cancer cell line (HT-29). Food Res Int 54 (1): 892901.

Shafek RE, Shafik NH, Michael HN, El-Hagrassi AM, Osman AF. 2015. Phytochemical studies and biological activity of Dodonaea viscosa flowers extract. J Chem Pharm Res 7 (5): 109-116.

Shah G, Singh PS, Mann AS, Shri R. 2011. Scientific basis for the chemical constituent and therapeutic use of Elaeocarpus species: a review. Int J Institutional Pharm Life Sci 1 (1): 267-278.

Shalabi M, Khilo K, Zakaria MM, Elsebaei MG, Abdo W, Awadin W. 2015. Anticancer activity of Aloe vera and Calligonum comosum extracts separetely on hepatocellular carcinoma cells. Asian Pac J Trop Bio Med 5 (5): 375-381.

Shao Q, Zhao L, BGCI, IUCN SSC Global Tree Specialist Group. 2019. Ficus fistulosa. The IUCN Red List of Threatened Species.

Shao, Suxia Z, Zhou J, Ting C, Ji M, Minliang K, Alan Y-L L, Lee J. 2016. Warfarin and coumarin-like Murraya paniculata extract downregulate EpCAM-mediated cell adhesion: individual components versus mixture for studying botanical metastatic chemopreventives. Sci Rep 6: 1-10.

Sharma JVC, Pitchaiah G, Satyavati D, Venkateswara Rao J, SanjayKumar H, Vikram (2011) In vitro anticancer activity of methanolic extract of roots of Glochidion zeylanicum (Gaertn.). Int J Res PharmBiomed Sci 2(2):760-764.

Shaw K, Roy S, Wilson B. 2014. Alnus japonica. The IUCN Red List of Threatened Species.

Shawky E, Takla SS, Hammoda HM, Darwish FA. 2018. Evaluation of the influence of green extraction solvents on the cytotoxic activities of Crinum (Amaryllidaeae) alkaloid extracts using in-vitro-in-silico approach. J Ethnopharmacol 227: 139-149.

Shen T, Chen X-M, Harder B, Long M, Wang X-N, Lou H-X, Wondark G, Ren D-M, Zhang D. 2014. Plant extracts of the family Lauraceae: A potential resource for chemopreventive agents that activate the nuclear factor-erythroid 2-related factor 2/antioxidant response element pathway. Plant Med 80 (05): 426-434.

Shen T, Chen X-M, Harder B, Long M, Wang X-N, Lou H-X, Wondark G, Ren D-M, Zhang D. 2014. Plant extracts of the family Lauraceae: A potential resource for chemopreventive agents that activate the nuclear factor-erythroid 2-related factor 2/antioxidant response element pathway. Plant Med 80 (05): 426-434. 
Shen YC, Shih-Sheng W, Pan YL et al. 2002. New taxane diterpenoids from the leaves and twigs of Taxus sumatrana. J Nat Prod 65 (12) 1848-1852.

Shi L-S, Wu C-H, Yang T-C, Yao C-W, Lin H-C, Chang W-L. 2014 Cytotoxic effect of triterpenoids from the root bark of Hibiscus syriacus. Fitoterapia 97: 184-191.

Shiratak Y, Motohash N, Tani S, Sakagam H, Satoh K, Nakashima H, Mahapatra SK, Ganguly K, Dastidar SG, Chak AN. 2001. In vitro biological activity of prenylflavanones. Anticancer Res 21: 275-280.

Shod P, R Shri. 2018. A Review on ethnomedicine, phytochemical and pharmacological aspects of Myrica esculenta. Indian J Pharm Sci 80 (1): 2-13.

Shukla A, Ashish G, Pramod M, Jain CP. 2016. Zizyphus oenoplia Mill: a review on pharmacological aspects. Adv Pharm J 1 (1): 8-12.

Sidiyasa K. 1998. Alstonia angustifolia. The IUCN Red List of Threatened Species

Singh NK, Singh VP. 2014. Anticancer activity of the roots of Ichnocarpus frutescens $\mathrm{R}$. Br. and isolated triterpenes. Pak J Pharm Sci 27 (1):187-191.

Smith P. 2019. The challenge for botanic garden science. Plants People Planet 1: 38-43.

Smith-Kielland I, Dornish JM, Malterud KE, Hvistendah G, Romming Chr, Bockman C, Kolsaker P, Stenstrom Y, Nordal A. 1996. Cytotoxic triterpenoids from the leaves of Euphorbia pulcherrima. Plant Med 62: 322-325.

Soib HH, Ware I, Yaakob H, Mukrish H, Sarmidi MR. 2015. Antioxidant and anti-cancer actvity of standardized extracts of three varieties of Ficus deltoidea's leaves. Jurnal Teknologi 77 (3): 19-25. [Indonesian]

Solipuram R, Koppula S, Hurst A, Harris K, Naragoni S, Fontenot K, Gray W. 2009. Molecular and biochemical effects of a kola nut extract on androgen receptor-mediated pathways. J Toxicol 2009: 116.

Solowey E, Lichtenstein M, Sallon S, Paavilainen H, Solowey E, Lorberboum-Galski H. 2010. Evaluating medicinal plants for anticancer activity. Sci World J 2014: 1-12.

Song Y, Bétrisey S, Kozlowski G. 2019. Pterocarya stenoptera. The IUCN Red List of Threatened Species.

Songsiang U, Hahnvajanawong C, Yenjai C. 2011. Cytotoxicity of chemical constituents from the stems of Dalbergia parviflora. Fitoterapia 82 (8): 1169-1174.

Soyingbe OS, Mongalo NI, Makhafola TJ. 2018. In vitro antibacterial and cytotoxic activity of leaf extracts of Centella asiatica (L.) Urb Warburgia salutaris (Bertol. F.) Chiov and Curtisia dentata (Burm. F.) C.A.Sm-Medicinal plants used in South Africa. BMC Complement Altern Med 18 (1): 315-324.

Stevens PF. 1998. Calophyllum soulattri. The IUCN Red List of Threatened Species.

Su Y-C, Ho C-L. 2017. Composition, in vitro cytotoxicity, anti-mildew and anti-wood-decay fungal activities of the fruit essential oil of Liquidambar formosana from Taiwan. Nat Prod Commun 12 (2): 287-290.

Su Y-C, Hsu K-P, Wang EI-C, Ho C-L. 2015. Composition, in vitro cytotoxic, and antimicrobial activities of the flower essential oil of Diospyros discolor from Taiwan. Nat Prod Commun 10 (7): 13111314.

Suastri NS, Hakim EH, Syah YM, Juliawaty LD, Achmad SA, Makmur L, Latif Z, Din L, Said IM. 2005. Metil linderon, senyawa calkon termodifikasi dari kayu batang Lindera polyantha (Lauraceae). Proceeding of The $6^{\text {th }}$ ITB-UKM Joint Seminar on Chem Bali, Indonesia, 17-18 Mei 2005. [Indonesian]

Subarnas A, Diantini A, Abdulah R, Zuhrotun A, Yamazaki C, Nakazawa M, Koyama H. 2012. Antiproliferative activity of primates-consumed plants against MCF7 human breast cancer cell lines. J Med Res 1 (4): $38-43$

Sun Z, Wang H, Wang J, Zhou L, Yang P. 2014. Chem. composition and anti-inflammatory, cytotoxic and antioxidant activities of essential oil from leaves of Mentha piperita grown in China. PLoS ONE 9 (12): 1 15.

Supratman U, Naibaho W, Salam S, Maharani R, Hidayat AT, Harneti D, Nurlelasari, Shiono Y. 2019. Cytotoxic triterpenoids from the bark of Chisocheton patens Blume (Meliaceae). Phyto Chem Lett 30: 81-87.

Suthiwong J, Boonloh K, Kukongviriyapan V, Yenjai C. 2018. Cytotoxicity against cholangiocarcinoma and HepG2 cell lines of lignans from Hernandia nymphaeifolia. Nat Prod Commun 13(1): 6163.
Suyatno, Hidajati N, Umami K, Sari IP. 2014. Flavonoids from Indonesian Silver Fern (Pityrogramma calomelanos) and their cytotoxicity against murine leukemia P-388 Cells. J Nat Sci Res 4 (15): 45-50.

Suzuki Y, Saito Y, Goto M, Newman DJ, O'Keefe BR, Lee K-H, Nakagawa-Goto K. (2018). (-)-Neocaryachine, an antiproliferative pavine alkaloid from Cryptocarya laevigata, induces DNA doublestrand breaks. J Nat Prod 80 (1): 220-224

Takeuchi S, Yoshiki Kono H, Mizutani T, Maruyama K, Nakayama R, Hiraoka A, Suzuki Y, Watanabe R, Kawarada A, Adisewojo SS. 1986. A bioactive polyphenolic constituent in the bark of Pterocarpus indicus Willd. I. Isolation and Characterization. Agric Biol Chem 50 (3): $569-573$

Tanaka R. 2000. Cancer chemopreventive agents, labdane diterpenoids from the stem bark of Thuja standishii (Gord.) Carr Cancer Lett 161 (2): $165-170$

Tanjung M, Mujahidin D, Hakim EH, Darmawan A, Syah YM. 2010. Geranylated flavonols from Macaranga rhizinoides. Nat Prod Commun 5 (8): 1209-1211.

Tavares W, Seca A. 2018. The current status of the pharmacological potential of Juniperus L. metabolites. Medicines 5 (3): 81-104.

Thomas P, Katsuki T, Farjon A. 2013. Cryptomeria japonica. The IUCN Red List of Threatened Species.

Thuaud F, Bernard Y, Türkeri G, Dirr R, Aubert G, Cresteil T, Baguet A, Tomasetto C, Svitkin Y, Sonenberg N, Nebigil CG, Désaubry L. 2009. Synthetic analogue of rocaglaol displays a potential and selective cytotoxicity in cancer cells: involvement of apoptosis inducing factor and caspase-12. J Med Chem 52 (16): 5176-5187.

Thun MJ, DeLAncey JO, Center MM, Jemal A, Ward EM. 2010. The global burden of cancer: priorities for prevention. Carcinogenesis 31 (1): 100-110.

Tian Q, Wang L, Sun X, Zeng F, Pan Q, Xue M. 2019. Scopoletin exerts anticancer effects on human cervical cancer cell lines by triggering apoptosis, cell cycle arrest, inhibition of cell invasion and PI3K/AKT signalling pathway. JBUON 24 (3): 997-1002.

Tu L, Zhao Y, Yu Z-Y, Cong Y-W, Xu G, Peng L-Y, Zhang P-T, Cheng X, Zhao Q-S. 2008. Six new dammarane triterpenoids from Viburnum cylindricum. Helvetica Chim Acta 91 (8): 1578-1587.

Turner A, Bond DR, Vuong QV, Chalmers A, Beckett EL, Weidenhofer J, Scarlett CJ. 2020. Elaeocarpus reticulatus fruit extracts reduce viability and induce apoptosis in pancreatic cancer cells in vitro. Mol Biol Rep 47 (3): 2073-2084

Twilley D, Langhansová L, Palaniswamy D, Lall N. 2017. Evaluation of traditionally used medicinal plants for anticancer, antioxidant, antiinflammatory and anti-viral (HPV-1) activity. South Afr J Bot 112: 494-500.

Uddin MN, Ahmed T, Pathan S, Al-Amin Md. M, Rana Md. S. 2015. Antioxidant and cytotoxic activity of stems of Smilax zeylanica in vitro. Basic Clin Physiol Pharmacol.

Ukiya M, Kikuchi T, Tokuda H, Tabata K, Kimura Y, Arai T, Ezaki Y, Oseto O, Suzuki T, Akihisa T. 2010. Antitumor-promoting effects and cytotoxic activities of dammar resin triterpenoids and their derivatives. Chem Biodivers 7 (8): 1871-1884.

Usman H, Hakim EH, Harlim T, Jalaluddin MN, Syah YM, Achmad SA, Takayama H. 2006. Cytotoxic chalcones and flavanones from the tree bark of Cryptocarya costata. Zeitschrift Für Naturforschung C 61 (34): 184-188.

Valente MJ, de Pinho PG, Henrique R, Pereira JA, Carvalho M. 2012. Further insights into chemical characterization through GC-MS and evaluation for anticancer potential of Dracaena draco leaf and fruit extracts. Food Chem Toxicol 50 (10): 3847-3852.

Valkute TR, Aratikatla EK, Gupta NA, Ganga S, Santra MK, Bhattacharya AK. 2018. Synthesis and anticancer studies of Michael adducts and Heck arylation production of sesquiterpene lactones, zaluzanin D and zaluzanin C from Vernonia arborea. RSC Adv 8 (67): 38289-38304.

Venkatesan T, Park E-J, Choi Y-W, Lee J, Kim Y-K. 2017. Antiinflammatory activity of Ternstroemia gymnantherastem bark extracts inbacterial lipopolysaccharide-stimulated RAW264.7 murine macrophage cells. Pharm Biol 55 (1): 837-846

Vuong QV, Hirun S, Chuen TLK, Goldsmith CD, Munro B, Bowyer BC, Chalmers AC, Sakoff JA, Phillips PA, Scarlett CJ. Physicochemical, antioxidant and anti-cancer activity of a Eucalyptus robusta $(\mathrm{Sm}$.) leaf aqueous extract. Ind Crops Prod 64 (2015): 167-174.

Wahyu W, Wijaya L, Teresa L. Wargasetia, Bachtiar I, Yellianty, Laksmitawati DR. 2013. Antioxidant, anticancer, and apoptosis- 
inducing effects of piper extracts in HeLa cells. J Exp Integr Med 3 (3): 225-230.

Wahyuni I, Dwianto W, Amin Y, Darmawan T. 2008. Timber tree species in Cibodas Botanic Gardens. Jurnal Ilmu dan Teknologi Hasil Hutan 1 (2): 93-101. [Indonesian]

Wang P, Yang HL, Yang YJ, Wang L, Lee SC. 2015. Overcome cancer cell drug resistance using natural products. Evidence-Based Complement Alt Med 2015: 1-14.

Wang T, Wu X, Liu Y, Luo Y, Li X, Zhou Y, Yang A, Yan Z, Ye L, Chen S, Fu J, Jiao X. 2018. Chemical constituents from ethanol extract of Polyalthia rumphii branches and their cytotoxicity evaluation. Rev Brasileira farmacognosia 28 (2): 235-238.

Wang Y-Q, Tan J-J, Tan C-H, Jiang S-H, Zhu D-Y. (2003). Halophilols A and B, two new stilbenes from Iris halophila. Plant Med 69: 779-781.

Wattanapiromsakul C, Wangsintaweekul B, Sangprapan P, Itharat A, Keawpradub N. 2005. Goniothalamin, a cytotoxic compound, isolated from Goniothalamus macrophyllus (Blume) Hook. F. \& Thomson var. Macrophyllus. Songklanakarin J Sci Technol 27 (2): 479-487.

Weerapreeyakul, Natthida, Sasipawan Machana and Sahapat Barusrux. 2016. Synergistic effects of melphalan and Pinus kesiya Royle ex Gordon (Simaosong) extracts on apoptosis induction in human cancer cells. Chin Med 11 (1).

Wegier A, Lorea Hernández F, Contreras A, Tobón W, Mastretta-Yanes A. 2017. Persea americana (errata version published in 2018). The IUCN Red List of Threatened Species.

Wheeler L, Beech E. 2019. Bixa orellana. The IUCN Red List of Threatened Species.

Wong FC, Woo CC, Hsu A, Tan BKH. 2013. The anti-cancer activities of Vernonia amygdalina extract in human breast cancer cell lines are mediated through caspase-dependent and p53-independent pathways. PLoS ONE 8(10): 1-15.

World Conservation Monitoring Centre. 1998. Alangium javanicum. The IUCN Red List of Threatened Species.

World Conservation Monitoring Centre. 1998. Alstonia scholaris. The IUCN Red List of Threatened Species.

World Conservation Monitoring Centre. 1998. Cratoxylum formosum. The IUCN Red List of Threatened Species.

World Conservation Monitoring Centre. 1998. Diospyros celebica. The IUCN Red List of Threatened Species.

World Conservation Monitoring Centre. 2018. Biancaea sappan (amended version of 1998 assessment). The IUCN Red List of Threatened Species 2018

Wu D-P, Lin T-Y, Lv J-Y, Chen W-Y, Bai L-R, Zhou Y, Huang J-L, Zhong Z-G. 2017. Cestrum nocturnum flower extracts attenuate proliferation and induce apoptosis in malignant cells through inducing DNA damage and inhibiting topoisomerase II activity. EvidenceBased Complement Altern Med 2017: 1-8.

Wu J, Yi W, Jin L, Hu D, Song B. 2012. Antiproliferative and cell apoptosis-inducing activities of compounds from Buddleja davidii in Mgc-803 cells. Cell Div 7: 20-10.

Wu L, Wu J, Chen S-P, Li Z-J, Zhang J, Yuan E, Ma G-Q, Jin L, Hu J-W. 2019. Chemical constituents of the twigs of Elaeocarpus sylvestris. Chem Nat Compd 55 (2): 324-326.

Wu Q, Yang X-W. 2009. The constituents of Cibotium barometz and their permeability in the human $\mathrm{CaCo}-2$ monolayer cell model. J Ethnopharmacol 125 (3): 417-422.

Wu T-S, Su C-R, Lee K-H. 2012. Cytotoxic and Anti-HIV Phenanthroindolizidine alkaloids from Cryptocarya chinensis. Nat Prod Commun 7 (6): 725-727.
Xu R-L, Wang R, Ding L, Shi Y-P. 2013. New cytotoxic steroids from the leaves of Clerodendrum trichotomum. Steroids 78 (7): 711-716.

Yang J, Chen J, Bi H, Gu H, Liu Z, Peng W. 2020. Molecules and functions of rosewood: Pterocarpus indicus. Therm Sci 24 (3A): $1869-1876$

Yang S, Zhao Q, Xiang H, Liu M, Zhang Q, Xue W, Song B, Yang S. 2013. Antiproliferative activity and apoptosis-inducing mechanism of constituents from Toona sinensis on human cancer cells. Cancer Cell Int 13(1): 12-19.

Ye J, BGCI \& IUCN SSC Global Tree Specialist Group. 2019. Glochidion zeylanicum. The IUCN Red List of Threatened Species.

Ye J, BGCI \& IUCN SSC Global Tree Specialist Group. 2019. Leea indica. The IUCN Red List of Threatened Species.

Ye J, Qin H, BGCI \& IUCN SSC Global Tree Specialist Group. 2019. Pistacia chinensis. The IUCN Red List of Threatened Species.

Ye J, Qin H, BGCI \& IUCN SSC Global Tree Specialist Group. 2019. Ziziphus oenopolia. The IUCN Red List of Threatened Species.

Yen H-F, Wang S-Y, Wu C-C, Lin W-Y, Wu T-Y, Chang F-R, Wang CK. 2020. Cytotoxicity, anti-platelet aggregation assay and chemical components analysis of thirty-eight kinds of essential oils. J Food Drug Anal 20 (2): 478-483

Yessoufou K. 2015. Antifungal, antibacterial and anticancer activities of Ficus drupacea L. stem bark extract and biological active isolated compounds. Ind Crops Prod 74: 752-758.

Yoon J-H, Pham T-H, Lee J, Lee J, Ryu H-W, Oh S-R, Oh J-W, Yoon DY. 2020. Methyl linderone suppresses TPA-Stimulated IL-8 and MMP-9 expression via the ERK/STAT3 pathway in MCF7 breast cancer cells. J Microbiol Biotechnol 30 (3): 325-332.

Yu J, Li G, Mu Y, Zhou H, Wang X, Yang P. 2019. Anti-breast cancer triterpenoid saponins from the thorns of Gleditsia sinensis. Nat Prod Res 33 (16): 2308-2313

Yu, S, Qin H, BGCI \& IUCN SSC Global Tree Specialist Group. 2019. Cerbera manghas. The IUCN Red List of Threatened Species.

Yudistira A. 2017. Uji aktivitas anti kanker payudara ekstrak daun pinang yaki (Areca vestiaria Giseke.) terhadap sel kanker payudara T-47D. Pharmacon Jurnal Ilmiah Farmasi 6 (4): 275-281. [Indonesian]

Yuenyongsawad S, Bunluepuech K, Wattanapiromsakul C, Tewtrakul S. 2013. Anti-cancer activity of compounds from Bauhinia strychnifolia stem. J. of EthnoPharmacol. 150(2): 765-769.

Zeng Y, Liu X, Lv Z, Peng Y. 2012. Effects of Ficus hirta Vahl. (Wuzhimaotao) extracts on growth inhibition of HeLa cells. Exp Toxicol Pathol 64 (7-8): 743--749.

Zhang J, Yu Y, Liu D, Liu Z. 2007. Extraction and composition of three naturally occurring anti-cancer alkaloids in Camptotheca acuminata seed and leaf extracts. Phyto Med 14 (1): 50-56.

Zhang Y-Y, Chen J-J, Li D-Q, Zhang Y, Wang X-B, Yao G-D, Song S-J. 2019. Network pharmacology uncovers anti-cancer activity of vibsane-type diterpenes from Viburnum odoratissimum. Nat Prod Res $1-4$

Zhao L, Yu S, BGCI \& IUCN SSC Global Tree Specialist Group. 2019. Diospyros japonica. The IUCN Red List of Threatened Species.

Zhao L, Yu S, BGCI \& IUCN SSC Global Tree Specialist Group. 2019. Elaeocarpus petiolatus. The IUCN Red List of Threatened Species.

Zhou T, Yang Y, Zhang H, Che Y, Wang W, Lv H, Li J, Wang Y, Hou S. 2014. Serenoa repens induces growth arrest, apoptosis and inactivation of STAT3 signaling in human glioma cells. Tech Cancer Res Treat 14 (6): 729-736. 
Table 3. List of CBG plants collection with anticancer properties

\begin{tabular}{|c|c|c|c|c|c|c|c|c|c|c|}
\hline Family & Species & $\begin{array}{c}\text { Common } \\
\text { name }\end{array}$ & Cell line & $\begin{array}{c}\text { Extraction } \\
\text { method }\end{array}$ & $\mathrm{IC}_{50}(\mu \mathrm{g} / \mathrm{ml})$ & Reference & $\begin{array}{c}\text { Anticancer activity } \\
\text { category* }\end{array}$ & Origin & $\begin{array}{l}\text { Cons. } \\
\text { status }\end{array}$ & $\begin{array}{c}\text { Location in } \\
\text { CBG }\end{array}$ \\
\hline Acanthaceae & $\begin{array}{l}\text { Acanthus montanus } \\
\text { (Nees) T.Anderson }\end{array}$ & Daruju & $\begin{array}{l}\text { BT-549 } \\
\text { BT-20 } \\
\text { PC-3 }\end{array}$ & Crude & $\begin{array}{l}>200 \\
>200 \\
>200\end{array}$ & $\begin{array}{l}\text { (Fadeyi et al. } \\
\text { 2013) }\end{array}$ & III & Trop. Africa & $\begin{array}{c}\text { LC } \\
\text { (Ghogu, } \\
\text { 2010) }\end{array}$ & I.D.34; I.F.12. \\
\hline Acanthaceae & $\begin{array}{c}\text { Strobilanthes cernua } \\
\text { Blume }\end{array}$ & $\begin{array}{c}\text { Bubukuan } \\
\text { kembang bidas }\end{array}$ & HeLa & Crude & 968.26 & $\begin{array}{c}\text { (Arbiastutie } \\
\text { 2017) }\end{array}$ & III & W. Java & N/A & $\begin{array}{l}\text { V.A.77-77A; } \\
\text { VII.B.171. }\end{array}$ \\
\hline Acoraceae & Acorus calamus L. & Jeringau & $\begin{array}{l}\text { MDA-MB-435S } \\
\text { Hep3B }\end{array}$ & Crude & $\begin{array}{l}13.71 \pm 6.66 \\
32.74 \pm 4.55\end{array}$ & $\begin{array}{l}\text { (Rajkumar et } \\
\text { al. 2009) }\end{array}$ & II & S. Sumatra & $\begin{array}{l}\text { LC (Lans- } \\
\text { down, } \\
2014)\end{array}$ & XIV.A.99-99a. \\
\hline Adoxaceae & $\begin{array}{c}\text { Sambucus javanica } \\
\text { Blume }\end{array}$ & Sangitan & N/A & N/A & N/A & $\begin{array}{l}\text { (Putra and } \\
\text { Rifa'i 2019) }\end{array}$ & $\begin{array}{l}\text { IV. Reduces necrotic cells } \\
\text { incidence in lung samples } \\
\text { of mice lung cancer }\end{array}$ & Java & $\begin{array}{l}\text { LC (BGCI } \\
\text { and IUCN, } \\
2018)\end{array}$ & $\begin{array}{l}\text { IV.A.52; } \\
\text { XII.A.14-14a. }\end{array}$ \\
\hline Adoxaceae & Sambucus nigra L. & Eur. elderberry & $\begin{array}{l}\text { MCF7 } \\
\text { LOVO }\end{array}$ & Crude & $\begin{array}{l}16.9 \pm 0.4 \\
12.9 \pm 0.3\end{array}$ & $\begin{array}{l}\text { (Gleńsk et al. } \\
\text { 2017) }\end{array}$ & II & S. Sumatra & $\begin{array}{l}\text { LC (Bilz, } \\
\text { 2020) }\end{array}$ & XII.A.50. \\
\hline Adoxaceae & $\begin{array}{c}\text { Viburnum } \\
\text { cylindricum Buch. } \\
\text { Ham. ex D. Don }\end{array}$ & $\begin{array}{l}\text { Tubeflower } \\
\text { viburnum }\end{array}$ & HL-60 & Subfraction & $>100$ & $\begin{array}{l}\text { (Tu et al. } \\
\text { 2008) }\end{array}$ & III & W. Java & N/A & $\begin{array}{c}\text { VI.E.119; } \\
\text { XVIII.A.35, } \\
\text { 43.XV.III.A.3 } \\
\text { 9-39a39b, 41, } \\
\text { 61. }\end{array}$ \\
\hline Adoxaceae & $\begin{array}{c}\text { Viburnum } \\
\text { odoratissimum Ker } \\
\text { Gawl. }\end{array}$ & $\begin{array}{c}\text { Sweet } \\
\text { viburnum }\end{array}$ & $\begin{array}{c}\text { HL-60 } \\
\text { A549 } \\
\text { SMMC-7721 } \\
\text { MCF7 } \\
\text { SW-480 }\end{array}$ & Subfraction & $\begin{array}{l}0.069 \\
0.320 \\
0.190 \\
0.223\end{array}$ & $\begin{array}{l}\text { (Zhu et al. } \\
\text { 2018; Y.-Y. } \\
\text { Zhang et al. } \\
\text { 2019) }\end{array}$ & $\begin{array}{l}\text { I.A. Contains } 15,18-\mathrm{O}- \\
\text { diacetyl-15-O- } \\
\text { methylvibsanin U, and in } \\
\text { silico study }\end{array}$ & $\begin{array}{l}\text { India, Japan, } \\
\text { S. China }\end{array}$ & $\begin{array}{l}\text { LC (Lai, et } \\
\text { al., 2019) }\end{array}$ & $\begin{array}{l}\text { I.B.21; I.K.3- } \\
\text { 3a; II.D.18. }\end{array}$ \\
\hline Adoxaceae & $\begin{array}{c}\text { Viburnum } \\
\text { sambucinum Reinw. } \\
\text { ex Blume }\end{array}$ & Buas-buas & $\begin{array}{c}\text { KB } \\
\text { LU-1 } \\
\text { HepG2 } \\
\text { MCF7 }\end{array}$ & Subfraction & $\begin{array}{l}2.09 \\
2.09 \\
2.04 \\
2.01\end{array}$ & $\begin{array}{l}\text { (T. T. Nguyen } \\
\text { et al. 2017) }\end{array}$ & $\begin{array}{c}\text { I.A } \\
\text { Contains hupehenol A }\end{array}$ & W. Java & $\begin{array}{l}\text { LC (Old- } \\
\text { field, } \\
2020)\end{array}$ & $\begin{array}{l}\text { XVIII.A.17, } \\
\text { 42-42a. }\end{array}$ \\
\hline Adoxaceae & $\begin{array}{l}\text { Viburnum suspensum } \\
\text { Lindl. }\end{array}$ & Sanandkwa & N/A & Subfraction & N/A & $\begin{array}{l}\text { (Fukuyama et } \\
\text { al. 2002) }\end{array}$ & $\begin{array}{c}\text { IV } \\
\text { Contains vibsanin }\end{array}$ & Japan & N/A & IV.A.16. \\
\hline Altingiaceae & $\begin{array}{c}\text { Liquidambar } \\
\text { formosana Hance }\end{array}$ & $\begin{array}{c}\text { Formosa sweet } \\
\text { gum }\end{array}$ & $\begin{array}{l}\text { OEC-M1 } \\
\text { J5 } \\
\text { A549 }\end{array}$ & Subfraction & $\begin{array}{l}15.6 \\
32.1 \\
19.3\end{array}$ & $\begin{array}{l}\text { (Su and Ho } \\
\text { 2017) }\end{array}$ & $\begin{array}{c}\text { II } \\
\text { Contains T-muurolol }\end{array}$ & $\begin{array}{l}\text { C. China, } \\
\text { Formosa }\end{array}$ & $\begin{array}{c}\text { LC } \\
\text { (Crowley, } \\
\text { et al., } \\
\text { 2018) }\end{array}$ & $\begin{array}{c}\text { III.F.37-37a- } \\
\text { 37b; IV.C. 58- } \\
\text { 58a; V. B.36 - } \\
\text { 36a; IX.A. } \\
\text { 104b. }\end{array}$ \\
\hline Amaryllidaceae & $\begin{array}{l}\text { Agapanthus africanus } \\
\text { (L.) Hoffmanns. }\end{array}$ & $\begin{array}{l}\text { Blue african } \\
\text { lily }\end{array}$ & N/A & N/A & N/A & $\begin{array}{l}\text { (Chanchal } \\
\text { et.al. 2018) }\end{array}$ & $\begin{array}{c}\text { IV } \\
\text { Contains isoliquiritigenin }\end{array}$ & S. Africa & N/A & $\begin{array}{l}\text { I.H.50; } \\
\text { III.D. } 20 \text {; } \\
\text { VI.C.50. }\end{array}$ \\
\hline
\end{tabular}




\begin{tabular}{|c|c|c|c|c|c|c|c|c|c|c|}
\hline Amaryllidaceae & $\begin{array}{l}\text { Crinum abyssinicum } \\
\text { Hochst. ex A.Rich. }\end{array}$ & Swamp lily & N/A & N/A & N/A & (Abebe 2016) & $\begin{array}{c}\text { IV } \\
\text { Contains lycorine, crimine, } \\
\text { narciclasine, } \\
\text { 3-epihalmanthidine, } \\
\text { crinamine, lycobetaine } \\
\text { precriwelline, crinamide, } \\
\text { crinafolidine, criasbetaine, } \\
\text { crinasiadine, crinasiatine } \\
\text { and } \\
\text { crotepoxide }\end{array}$ & N/A & N/A & I.G.137. \\
\hline Amaryllidaceae & $\begin{array}{c}\text { Crinum macowanii } \\
\text { Baker }\end{array}$ & $\begin{array}{l}\text { Common vlei- } \\
\text { lily }\end{array}$ & $\begin{array}{c}\text { A549 } \\
\text { U87-MG }\end{array}$ & Crude & $\begin{array}{c}12.5-25 \\
6.25\end{array}$ & $\begin{array}{c}\text { (Sebola et al. } \\
\text { 2019) }\end{array}$ & $\begin{array}{l}\text { I.D. Contains bacterial } \\
\text { endophytes Acinetobacter } \\
\text { guillouiae that displayed } \\
\text { anticancer activity. }\end{array}$ & Trop. Africa & N/A & I.H.31. \\
\hline Amaryllidaceae & $\begin{array}{c}\text { Crinum } \times \text { powellii } \\
\text { Baker }\end{array}$ & Cape lily & $\begin{array}{l}\text { HepG2 } \\
\text { HCT-116 }\end{array}$ & Crude & $\begin{array}{l}13.78 \\
17.27\end{array}$ & $\begin{array}{c}\text { (Shawky et al. } \\
\text { 2018) }\end{array}$ & II & $\begin{array}{l}\text { Hybrid } \\
\text { Origin }\end{array}$ & N/A & $\begin{array}{c}\text { I.H.34; I.K.21 } \\
\text {-21a-21b; } \\
\text {.A. } 15 .\end{array}$ \\
\hline Amaryllidaceae & $\begin{array}{l}\text { Crinum zeylanicum } \\
\text { (L.) L. }\end{array}$ & $\begin{array}{l}\text { Ceylon swamp } \\
\text { lily }\end{array}$ & $\begin{array}{c}\text { CCRF-CEM } \\
\text { CEM/ADR5000 } \\
\text { MDA-MB-231 } \\
\text { MDA-MB-231/ } \\
\text { BCRP } \\
\text { HCT-116 } \\
\text { (p53+/+) } \\
\text { HCT-116 } \\
\text { (p53-/-) }\end{array}$ & Crude & $\begin{array}{l}17.22 \pm 2.19 \\
23.67 \pm 1.97 \\
18.01 \pm 1.61 \\
11.18 \pm 1.11 \\
4.32 \pm 0.52 \\
7.45 \pm 0.64\end{array}$ & $\begin{array}{l}\text { (Berkov et al. } \\
\text { 2011; Kuete et } \\
\text { al. 2013) }\end{array}$ & $\begin{array}{c}\text { I.C } \\
\text { Contains crinine }\end{array}$ & $\begin{array}{c}\text { Africa, Trop. } \\
\text { Asia }\end{array}$ & N/A & I.H.38. \\
\hline Amaryllidaceae & $\begin{array}{l}\text { Hymenocallis } \\
\text { speciosa (L.f. ex } \\
\text { Salisb.) Salisb. }\end{array}$ & $\begin{array}{l}\text { Bakung air } \\
\text { mancur, spider } \\
\text { lily }\end{array}$ & N/A & N/A & N/A & $\begin{array}{l}\text { (Kornienko } \\
\text { and Evidente } \\
\text { 2008) }\end{array}$ & $\begin{array}{c}\text { IV } \\
\text { Contains narciclasine } \\
\text { (lycoricidinol) and } \\
\text { pancratistatin, }\end{array}$ & N/A & N/A & II. 10. \\
\hline Anacardiaceae & $\begin{array}{c}\text { Pistacia chinensis } \\
\text { Bunge }\end{array}$ & Pistacia cina & $\begin{array}{l}\text { PC-3 } \\
\text { HepG2 } \\
\text { MCF7 } \\
\text { A549 }\end{array}$ & Crude & $\begin{array}{c}30.29 \\
132.30 \\
27.64 \\
83.53\end{array}$ & $\begin{array}{c}\text { (Kirollos et al. } \\
\text { 2019) }\end{array}$ & II & China & $\begin{array}{l}\text { LC (Ye, et } \\
\text { al. , 2019) }\end{array}$ & XV.B.22. \\
\hline Anacardiaceae & $\begin{array}{c}\text { Schinus } \\
\text { terebinthifolius } \\
\text { Raddi }\end{array}$ & Pink pepper & $\begin{array}{l}\text { HepG2 } \\
\text { CaCo-2 }\end{array}$ & Crude & $\begin{array}{l}1.56 \\
3.77\end{array}$ & $\begin{array}{l}\text { (El-Nashar et } \\
\text { al. 2019) }\end{array}$ & I.D & Brazil & N/A & $\begin{array}{c}\text { IV.C.10; } \\
\text { XV.B.11-11b. }\end{array}$ \\
\hline Anacardiaceae & $\begin{array}{c}\text { Schinus } \\
\text { weinmannifolius } \\
\text { Engl. }\end{array}$ & N/A & $\begin{array}{c}\text { HT-29 } \\
\text { NCI-H460 }\end{array}$ & Crude & $\begin{array}{l}5 \\
2\end{array}$ & $\begin{array}{l}\text { (Monks et al. } \\
\text { 2002) }\end{array}$ & I.D & Brazil & N/A & $\begin{array}{l}\text { IV.C.11; } \\
\text { XIII.A.15a- } \\
\text { 15b. }\end{array}$ \\
\hline
\end{tabular}




\begin{tabular}{|c|c|c|c|c|c|c|c|c|c|c|}
\hline Annonaceae & $\begin{array}{l}\text { Cananga odorata } \\
\text { (Lam.) Hook.f. and } \\
\text { Thomson }\end{array}$ & $\begin{array}{l}\text { Ylang-ylang, } \\
\text { kenanga }\end{array}$ & $\begin{array}{l}\text { HepG2 } \\
\text { Hep2,2,15 }\end{array}$ & Subfraction & $\begin{array}{l}0.01 \\
0.01\end{array}$ & $\begin{array}{l}\text { (Hsieh et al. } \\
\text { 2001) }\end{array}$ & $\begin{array}{c}\text { I.B } \\
\text { Contains cryptomeridiol } \\
\text { 11-R-L-rhamnoside and } \gamma \text { - } \\
\text { eudesmol }\end{array}$ & $\begin{array}{c}\text { Java } \\
\text { Aceh } \\
\text { W. Java N. } \\
\text { Sumatra }\end{array}$ & $\begin{array}{c}\text { LC (IUCN } \\
\text { and BGCI, } \\
2019)\end{array}$ & $\begin{array}{l}\text { VI.D.138- } \\
\quad \text { 138a; } \\
\text { VI.D.146; } \\
\text { VI.D.142; } \\
\text { VI.D. } 165 .\end{array}$ \\
\hline Annonaceae & $\begin{array}{c}\text { Goniothalamus } \\
\text { macrophyllus } \\
\text { (Blume) Hook.f. and } \\
\text { Thomson }\end{array}$ & Ki Cantung & $\begin{array}{l}\text { COR-L23 } \\
\text { LS-174T } \\
\text { MCF7 }\end{array}$ & Crude & $\begin{array}{l}3.16 \pm 01.14 \\
3.80 \pm 0.00 \\
4.66 \pm 0.04\end{array}$ & $\begin{array}{l}\text { (Wattana- } \\
\text { piromsakul et } \\
\text { al. 2005) }\end{array}$ & $\begin{array}{c}\text { I.C } \\
\text { Contains goniothalamin }\end{array}$ & $\begin{array}{l}\text { W. Java } \\
\text { C. Sulawesi }\end{array}$ & N/A & $\begin{array}{l}\text { VI.D. } 115,128, \\
145,179 ; \\
\text { VI.D. } 177 .\end{array}$ \\
\hline Annonaceae & $\begin{array}{l}\text { Polyalthia rumphii (E } \\
\text { lume ex Hensch.) } \\
\text { Merr. }\end{array}$ & Mempisang & $\begin{array}{l}\text { HeLa } \\
\text { MCF7 } \\
\text { A549 }\end{array}$ & Subfraction & $\begin{array}{l}26.9 \\
32.9 \\
33.4\end{array}$ & $\begin{array}{l}\text { (T. Wang et al. } \\
\text { 2018) }\end{array}$ & $\begin{array}{c}\text { II } \\
\text { Contains N-trans- } \\
\text { cinnamoyltyramine and } \\
\text { northalifoline }\end{array}$ & W. Java & N/A & VI.D.180. \\
\hline Annonaceae & $\begin{array}{l}\text { Polyalthia subcordat } \mathrm{I} \\
a \text { (Blume) Blume }\end{array}$ & Nona leuweung & HeLa & Crude & $>1000$ & $\begin{array}{l}\text { (Arbiastutie } \\
\text { 2017) }\end{array}$ & III & $\begin{array}{l}\text { Java } \\
\text { W. Java }\end{array}$ & N/A & $\begin{array}{l}\text { VI.D.60; } \\
\text { VI.D.192. }\end{array}$ \\
\hline Annonaceae & $\begin{array}{l}\text { Uvaria grandi- } \\
\text { flora Roxb. ex } \\
\text { Hornem. }\end{array}$ & $\begin{array}{c}\text { Akar } \\
\text { mempisang }\end{array}$ & $\begin{array}{l}\text { MDA-MB-231 } \\
\text { HepG2 }\end{array}$ & Subfraction & $\begin{array}{c}20.82 \\
>30.72\end{array}$ & $\begin{array}{l}\text { (Seangphak- } \\
\text { dee et al. } \\
\text { 2013) }\end{array}$ & III. Contains (-)-zeylenol & W. Java & N/A & $\begin{array}{l}\text { V.B.45-45a; } \\
\text { 46-46a. }\end{array}$ \\
\hline Apiaceae & $\begin{array}{l}\text { Centella asiatica } \\
\text { (L.) Urb. }\end{array}$ & Pegagan & $\begin{array}{c}\text { MCF7 } \\
\text { CaCo-2 } \\
\text { HeLa } \\
\text { A549 }\end{array}$ & Crude & $\begin{array}{l}49.36 \pm 0.0 \\
81.88 \pm 1.4 \\
56.88 \pm 0.7 \\
46.49 \pm 0.0\end{array}$ & $\begin{array}{l}\text { (Soyingbe et } \\
\text { al. 2018) }\end{array}$ & $\begin{array}{c}\text { II } \\
\text { Contains asiatic acid }\end{array}$ & $\begin{array}{l}\text { S. Africa, S. } \\
\text { E. Asia }\end{array}$ & $\begin{array}{c}\text { LC } \\
\text { (Lansd- } \\
\text { own, } \\
\text { 2019) }\end{array}$ & I.G.183. \\
\hline Apocynaceae & $\begin{array}{l}\text { Alstonia angustifolia } \\
\text { Wall. ex A.DC. }\end{array}$ & $\begin{array}{l}\text { Red-leafed } \\
\text { pulai }\end{array}$ & HT-29 & Subfraction & 4.61 & $\begin{array}{l}\text { (Pan et al. } \\
\text { 2014) }\end{array}$ & $\begin{array}{c}\text { II } \\
\text { Contains villalstonidine } \mathrm{E}\end{array}$ & W. Sumatra & $\begin{array}{l}\text { LC (Sidi- } \\
\text { yasa, } \\
1998)\end{array}$ & $\begin{array}{l}\text { VII.C.316- } \\
\text { 316a. }\end{array}$ \\
\hline Apocynaceae & $\begin{array}{l}\text { Alstonia scholaris (L. I } \\
\text { ) R. Br. }\end{array}$ & $\begin{array}{l}\text { Pulai, jelutung, } \\
\text { lame }\end{array}$ & $\begin{array}{c}\text { HeLa } \\
\text { HepG2 } \\
\text { HL-60 } \\
\text { KB } \\
\text { MCF7 }\end{array}$ & Crude & $\begin{array}{c}5.53 \\
25 \\
11.16 \\
10 \\
29.76\end{array}$ & $\begin{array}{l}\text { (Jagetia and } \\
\text { Baliga 2006) }\end{array}$ & I.C & $\begin{array}{c}\text { Aceh } \\
\text { Kaliman-tan } \\
\text { W. Java }\end{array}$ & $\begin{array}{l}\text { LC (World } \\
\text { Conser- } \\
\text { vation } \\
\text { Monitor- } \\
\text { ing Centre, } \\
1998 \text { ) }\end{array}$ & $\begin{array}{l}\text { VII.C.120- } \\
\text { 120a;.XVIII. } \\
\text { B.30-30a; } \\
\text { VII.C.327- } \\
\text { 327a-327b; } \\
\text { 350-350a; } \\
\text { 442-442a; }\end{array}$ \\
\hline Apocynaceae & $\begin{array}{c}\text { Asclepias } \\
\text { curassavica } \mathrm{L} .\end{array}$ & Kapas cinde & $\begin{array}{l}\text { HepG2 } \\
\text { Raji }\end{array}$ & Subfraction & 10.64 & $\begin{array}{l}\text { (Li et al. 2009; } \\
\text { Iqbal et al. } \\
\text { 2017) }\end{array}$ & $\begin{array}{c}\text { III } \\
\text { Contains asclepin }\end{array}$ & France & N/A & XII.B.52. \\
\hline Apocynaceae & Cerbera manghas L. & Bintaro & $\begin{array}{c}\text { KB } \\
\text { BC } \\
\text { NCI-H187 }\end{array}$ & Subfraction & $\begin{array}{c}0.05 \\
0.0006 \\
0.1\end{array}$ & $\begin{array}{l}\text { (Cheenpra-cha } \\
\text { et al. 2004) }\end{array}$ & $\begin{array}{l}\text { I.A. Contains cardenolide } \\
\text { glycoside, } \\
\text { deacetyltanghinin, and } \\
\text { tanghinin }\end{array}$ & W. Java & $\begin{array}{l}\text { LC (Yu, et } \\
\text { al., 2019) }\end{array}$ & $\begin{array}{l}\text { VIII.C.106- } \\
\text { 106a-106b. }\end{array}$ \\
\hline Apocynaceae & $\begin{array}{l}\text { Ichnocarpus } \\
\text { frutescens }(\mathrm{L} .) \\
\text { W.T.Aiton }\end{array}$ & Black creeper & $\begin{array}{c}\text { MCF7 } \\
\text { BEL-7402 } \\
\text { SPC-A1 } \\
\text { SGC-7901 }\end{array}$ & Crude & $\begin{array}{l}172.2 \pm 3.9 \\
167.2 \pm 3.2 \\
155.3 \pm 4.1 \\
131.7 \pm 1.5 \\
\end{array}$ & $\begin{array}{l}\text { (Singh and } \\
\text { Singh 2014) }\end{array}$ & III & N/A & N/A & CL.60 \\
\hline
\end{tabular}




\begin{tabular}{|c|c|c|c|c|c|c|c|c|c|c|}
\hline Apocynaceae & $\begin{array}{l}\text { Ochrosia elliptica } \\
\text { Labill. }\end{array}$ & $\begin{array}{l}\text { Elliptic yellow } \\
\text { wood }\end{array}$ & $\begin{array}{c}\text { MCF7 } \\
\text { MDA-MB-231 }\end{array}$ & Subtraction & $\begin{array}{l}0.11 \pm 0.02 \\
0.11 \pm 0.01\end{array}$ & $\begin{array}{l}\text { (El-shiekh et } \\
\text { al. 2017) }\end{array}$ & $\begin{array}{c}\text { I.B } \\
\text { Contains 9- } \\
\text { methoxyellipticine }\end{array}$ & Kaliman-tan & N/A & VIl.B.76. \\
\hline Apocynaceae & $\begin{array}{l}\text { Tabernaemontana mc } \mathrm{L} \\
\text { crocarpa Jack }\end{array}$ & Lelutung Tokak & L1210 & Crude & $\begin{array}{l}6.039 \\
7.145\end{array}$ & $\begin{array}{l}\text { (Pratiwi et al. } \\
\text { 2014) }\end{array}$ & I.D & $\begin{array}{l}\text { W.Java } \\
\text { W. Sumatra }\end{array}$ & $\begin{array}{l}\text { LC (BGCI } \\
\text { and IUCN, } \\
2018)\end{array}$ & $\begin{array}{l}\text { VII.C.408; } \\
\text { VII.C.404- } \\
\text { 404a. }\end{array}$ \\
\hline Araliaceae & $\begin{array}{l}\text { Panax ginseng } \\
\text { C.A.Mey }\end{array}$ & Ginseng & $\begin{array}{l}\text { MK-1 } \\
\text { B16 } \\
\text { L929 }\end{array}$ & Subfraction & $\begin{array}{l}0.027 \pm 0.00 \\
1.23 \pm 0.03 \\
2.50 \pm 0.28\end{array}$ & $\begin{array}{l}\text { (Matsunaga et } \\
\text { al. 1990; K.-K. } \\
\text { Li et al. 2019) }\end{array}$ & $\begin{array}{c}\text { I.A } \\
\text { Contains panaxylol, } \\
\text { panaxydol, panaxytriol, and } \\
\text { 24(S)-floralginsenoside }\end{array}$ & C. Java & N/A & I.G.209. \\
\hline Arecaceae & $\begin{array}{l}\text { Areca vestiaria } \\
\text { Giseke }\end{array}$ & Pinang merah & $\mathrm{T}-47 \mathrm{D}$ & Crude & 290.68 & $\begin{array}{l}\text { (Yudistira } \\
\text { 2017) }\end{array}$ & III & $\begin{array}{l}\text { Borneo to } \\
\text { Maluku } \\
\text { Sulawesi } \\
\text { C. Sulawesi }\end{array}$ & N/A & $\begin{array}{l}\text { X.A.21-21a; } \\
\text { II.B.20; } \\
\text { II.B. } 49 ; \\
\text { XIII.A. } 117 .\end{array}$ \\
\hline Arecaceae & $\begin{array}{l}\text { Serenoa repens } \\
\text { (W.Bartram) Small }\end{array}$ & Saw palmetto & $\begin{array}{l}\text { U87 } \\
\text { U251 }\end{array}$ & Crude & $\begin{array}{l}1,0 \\
1,1\end{array}$ & $\begin{array}{l}\text { (Habib et al. } \\
\text { 2005, Zhou et } \\
\text { al. 2015) }\end{array}$ & $\begin{array}{c}\text { I.D } \\
\text { Commercial cancer drug } \\
\text { Permixon }{ }^{\circledR}\end{array}$ & China & N/A & XIII.A.59. \\
\hline Aristolochiaceae & $\begin{array}{c}\text { Aristolochia trilobata } \\
\text { L. }\end{array}$ & $\begin{array}{l}\text { Bejuco de } \\
\text { santiago }\end{array}$ & N/A & N/A & N/A & $\begin{array}{l}\text { (Santos et al. } \\
\text { 2014; Chang et } \\
\text { al. 2015) }\end{array}$ & $\begin{array}{c}\text { IV } \\
\text { Contains linalool }\end{array}$ & Nether-lands & N/A & I.A. 87 \\
\hline Asparagaceae & Agave americana $\mathrm{L}$. & $\begin{array}{l}\text { Lidah buaya } \\
\text { america }\end{array}$ & MCF7 & Crude & 5 & $\begin{array}{l}\text { (Pandey et al. } \\
\text { 2019) }\end{array}$ & I.D & Mexico & $\begin{array}{l}\text { LC } \\
\text { (García- } \\
\text { Mendoza } \\
\text { et al,.. } \\
\text { 2019) }\end{array}$ & $\begin{array}{l}\text { II.D. } 17-17 \mathrm{a}- \\
\text { 17b; IV.B.7a, } \\
27 .\end{array}$ \\
\hline Asparagaceae & $\begin{array}{l}\text { Agave attenuata } \\
\text { Salm-Dyck }\end{array}$ & Fox tail & N/A & N/A & N/A & $\begin{array}{l}\text { (Rizwan et al. } \\
\text { 2012) }\end{array}$ & $\begin{array}{c}\text { IV } \\
\text { Antiinflamation }\end{array}$ & Mexico & $\begin{array}{c}\text { LC } \\
\text { (García- } \\
\text { Mendoza, } \\
\text { et al. } \\
\text { 2019) }\end{array}$ & $\begin{array}{l}\text { I.D.24-24a- } \\
\text { 24c; IV.B.49. }\end{array}$ \\
\hline Asparagaceae & $\begin{array}{l}\text { Agave salmiana Otto } \\
\text { ex Salm-Dyck }\end{array}$ & Giant agave & HT-29 & Crude & $3.8 \pm 1.3$ & $\begin{array}{l}\text { (Santos-Zea et } \\
\text { al. 2016) }\end{array}$ & I.D & Mexico & $\begin{array}{c}\text { LC } \\
\text { (García- } \\
\text { Mendoza } \\
\text { et al. } \\
\text { 2019) }\end{array}$ & II.D.36-36a. \\
\hline Asparagaceae & $\begin{array}{c}\text { Dracaena draco }(\mathrm{L} .) \\
\text { L. }\end{array}$ & Dragon tree & $\begin{array}{l}\mathrm{CaCo}-2 \\
\mathrm{~A} 498\end{array}$ & Crude & $\begin{array}{c}85.1 \pm 6.9 \\
176.2 \pm 18.2\end{array}$ & $\begin{array}{l}\text { (Valente et al. } \\
\text { 2012) }\end{array}$ & III & Canary Isl. & $\begin{array}{c}\text { VU } \\
\text { (Bañareset } \\
\text { al. 1998) }\end{array}$ & I.E. 2. \\
\hline Asparagaceae & $\begin{array}{l}\text { Eucomis autumnalis } \\
\text { (Mill.) Chitt. }\end{array}$ & Pineapple Lily & Huh7 & Crude & 7.8 & $\begin{array}{l}\text { (Bisi-Johnson } \\
\text { et al. 2011) }\end{array}$ & I.D & S. Africa & N/A & I.I.28. \\
\hline Asparagaceae & $\begin{array}{l}\text { Eucomis comosa } \\
\text { (Houtt.) Wehrh. }\end{array}$ & $\begin{array}{l}\text { Slender } \\
\text { pineapple } \\
\text { flower }\end{array}$ & N/A & N/A & N/A & $\begin{array}{l}\text { (Masondo et } \\
\text { al. 2014) }\end{array}$ & $\begin{array}{c}\text { IV } \\
\text { Inhibitor COX-1 and COX- } \\
2\end{array}$ & Africa & N/A & $\begin{array}{l}\text { I.G.53; I.H. } 8, \\
\text { 45, 58; } \\
\text { III.D. } 18 .\end{array}$ \\
\hline
\end{tabular}




\begin{tabular}{|c|c|c|c|c|c|c|c|c|c|c|}
\hline Asparagaceae & $\begin{array}{c}\text { Sansevieria } \\
\text { ehrenbergii } \\
\text { Schweinf. ex Baker }\end{array}$ & $\begin{array}{c}\text { Samurai } \\
\text { sansevieria }\end{array}$ & $\begin{array}{c}\text { BxPX-3 } \\
\text { MCF7 } \\
\text { SF-268 } \\
\text { NCI-H460 } \\
\text { KM20L2 } \\
\text { DU-145 }\end{array}$ & Subfraction & $\begin{array}{l}0.93 \\
0.62 \\
0.68 \\
0.26 \\
0.22 \\
0.42\end{array}$ & $\begin{array}{l}\text { (Magadula and } \\
\text { Erasto 2009) }\end{array}$ & $\begin{array}{c}\text { I.A } \\
\text { Contains sansevistatin } 2\end{array}$ & Abyssinia & N/A & I.D.11. \\
\hline Asparagaceae & Yucca aloifolia $\mathrm{L}$. & $\begin{array}{l}\text { Spanish } \\
\text { bayonet }\end{array}$ & $\begin{array}{l}\text { A549 } \\
\text { HepG2 } \\
\text { CaCo-2 } \\
\text { MCF7 }\end{array}$ & Crude & $\begin{array}{l}271.5 \\
61.55 \\
871.5 \\
1584\end{array}$ & $\begin{array}{l}\text { (El Hawary et } \\
\text { al. 2018) }\end{array}$ & II & $\begin{array}{l}\text { S. America } \\
\text { Mexico }\end{array}$ & N/A & $\begin{array}{l}\text { XII.A.30-30a- } \\
\text { 30b; II.D.10- } \\
\text { 10a-10b. }\end{array}$ \\
\hline Asparagaceae & Yucca glauca Nutt. & $\begin{array}{l}\text { Yuka, } \\
\text { soapweed } \\
\text { yucca }\end{array}$ & B16 & Crude & N/A & (Patel 2012) & $\begin{array}{c}\text { IV } \\
\text { Contains yuccaol }\end{array}$ & N/A & $\begin{array}{l}\text { LC (Rowe } \\
\text { and Puente } \\
\text { 2020) }\end{array}$ & XII.A.23-23a \\
\hline Asparagaceae & Yucca gloriosa $\mathrm{L}$. & Yuka amerika & HBL-100 & Crude & $>156.25$ & $\begin{array}{l}\text { (Obaid et al. } \\
\text { 2017) }\end{array}$ & III & N/A & N/A & $\begin{array}{l}\text { I.D.7; IV.B.10; } \\
\text { XII.A.19. }\end{array}$ \\
\hline Athyriaceae & $\begin{array}{c}\text { Diplazium } \\
\text { esculentum (Retz.) } \\
\text { Sw. }\end{array}$ & Paku sayur & MDA-MB-231 & Crude & 1.62 & $\begin{array}{l}\text { (Rahmat et al. } \\
\text { 2003) }\end{array}$ & I.D & N/A & $\begin{array}{l}\text { LC (Iruda- } \\
\text { yaraj } \\
2011)\end{array}$ & PT.122. \\
\hline Berberidaceae & $\begin{array}{l}\text { Mahonia fortunei } \\
\text { (Lindl.) Fedde }\end{array}$ & Ki koneng & $\begin{array}{c}\text { MCF7 } \\
\text { A431 } \\
\text { U87-MG }\end{array}$ & Crude & $>50$ & $\begin{array}{l}\text { (Rezadoost et } \\
\text { al. 2019) }\end{array}$ & III & China & N/A & $\begin{array}{l}\text { I.K.31; } \\
\text { IV.A.13-13a; } \\
\text { V.A. } 20 .\end{array}$ \\
\hline Betulaceae & $\begin{array}{l}\text { Alnus japonica } \\
\text { (Thunb.) Steud }\end{array}$ & Alder & $\begin{array}{c}\text { B16 } \\
\text { SNU-1 } \\
\text { SNU-354 } \\
\text { SNU-C4 }\end{array}$ & Subfraction & $\begin{array}{c}8.12 \\
13.39 \\
23.15 \\
21.53\end{array}$ & $\begin{array}{l}\text { (Choi et al. } \\
\text { 2008) }\end{array}$ & $\begin{array}{c}\text { II } \\
\text { Contains oregonin, } 1,7-\text { bis- } \\
(3,4-\text { dihydroxyphenyl)- } \\
\text { heptane-3-O-- } \beta \text {-D- } \\
\text { glucopyranosyl }(1 \rightarrow 3)-\beta-D- \\
\text { xylopyranoside, and } \\
\text { platyphylloside }\end{array}$ & $\begin{array}{l}\text { Formosa, } \\
\text { N.E. Asia }\end{array}$ & $\begin{array}{l}\text { LC (Shaw } \\
\text { et al. } \\
\text { 2014) }\end{array}$ & $\begin{array}{c}\text { VI.C.46a, 82- } \\
\text { 82a; VII.C.70- } \\
\text { 70b-70c; } \\
\text { VIII.B.207; } \\
\text { IX.A.92-92a. }\end{array}$ \\
\hline Bignoniaceae & $\begin{array}{l}\text { Oroxylum indicum } \\
\text { (L.) Kurz }\end{array}$ & $\begin{array}{l}\text { Bungli, } \\
\text { pongporang }\end{array}$ & Hela & Crude & $112.3 \pm 4.4$ & $\begin{array}{l}\text { (Moirang-them } \\
\text { et al. 2013) }\end{array}$ & III & Kalimantan & N/A & $\begin{array}{l}\text { VIII.C.20-20a, } \\
\text { 91-91a. }\end{array}$ \\
\hline Bignoniaceae & $\begin{array}{c}\text { Tabebuia hypoleuca } \\
\text { (C. Wright ex } \\
\text { Sauvalle) Urb. }\end{array}$ & Bunga tabebuya & $\begin{array}{c}\text { UACC-62 MCF7 } \\
786-0\end{array}$ & Crude & N/A & $\begin{array}{l}\text { (Perera et al. } \\
\text { 2019) }\end{array}$ & $\begin{array}{l}\text { I.C. Due to Total growth } \\
\text { inhibition (TGI), it was } \\
\text { classified as potent activity } \\
\text { to three assayed cell lines. }\end{array}$ & Cuba & $\begin{array}{c}\text { LC } \\
\text { (Areces- } \\
\text { Mallea } \\
\text { 1998) }\end{array}$ & VI.A.37. \\
\hline
\end{tabular}




\begin{tabular}{|c|c|c|c|c|c|c|c|c|c|c|}
\hline Bignoniaceae & $\begin{array}{l}\text { Tecoma stans (L.) } \\
\text { Juss. ex Kunth }\end{array}$ & $\begin{array}{l}\text { Yellow elder, } \\
\text { bunga terompet } \\
\text { kuning }\end{array}$ & $\begin{array}{c}\text { HT-29 } \\
\text { NCI-H460 }\end{array}$ & Crude & $\begin{array}{l}90 \\
97\end{array}$ & $\begin{array}{l}\text { (Monks et al. } \\
\text { 2002) }\end{array}$ & II & $\begin{array}{l}\text { Trop. } \\
\text { America }\end{array}$ & $\begin{array}{l}\text { LC (BGCI } \\
\text { and IUCN } \\
2019)\end{array}$ & XII.B.32-32a. \\
\hline Bixaceae & Bixa orellana $\mathrm{L}$. & $\begin{array}{l}\text { Kesumba, } \\
\text { prada, galuga }\end{array}$ & B16F10 & Crude & $121.60 \pm 6.2$ & $\begin{array}{l}\text { (Kumar and } \\
\text { Periyasamy } \\
\text { 2016) }\end{array}$ & III & Australia & $\begin{array}{c}\text { LC } \\
\text { (Whee-ler } \\
\text { and Beech } \\
\text { 2019) }\end{array}$ & VI.A.38a. \\
\hline Blechnaceae & $\begin{array}{c}\text { Blechnum orientale } \\
\text { L. }\end{array}$ & $\begin{array}{c}\text { Paku leuncir, } \\
\text { paku lubang }\end{array}$ & HT-29 & Crude & $27.5 \pm 1.4$ & $\begin{array}{l}\text { (H. Y. Lai et } \\
\text { al. 2010) }\end{array}$ & II & N/A & N/A & PT.74. \\
\hline Buxaceae & $\begin{array}{l}\text { Buxus microphylla } \\
\text { Siebold and Zucc. }\end{array}$ & $\begin{array}{l}\text { Japanese } \\
\text { boxwood }\end{array}$ & $\begin{array}{c}\text { HL-60 } \\
\text { SMMC-7721 } \\
\text { A549 } \\
\text { MCF7 } \\
\text { SW-480 }\end{array}$ & Subfraction & $\begin{array}{l}8.20 \\
9.20 \\
6.95 \\
2.67 \\
8.10\end{array}$ & $\begin{array}{l}\text { (Bai et al. } \\
\text { 2017) }\end{array}$ & $\begin{array}{c}\text { I.A } \\
\text { Contains buxmicrophylline } \\
\text { R }\end{array}$ & China & $\begin{array}{c}\text { LC (BGCI } \\
\text { and IUCN, } \\
2019)\end{array}$ & II.C.70-70a \\
\hline Buxaceae & $\begin{array}{l}\text { Buxus papillosa } \\
\text { C.K.Schneid }\end{array}$ & Boxwood & $\begin{array}{c}\text { MCF7 } \\
\text { MDA-MB-231 } \\
\text { CaSki } \\
\text { DU-145 } \\
\text { SW-480 }\end{array}$ & Crude & $\begin{array}{l}26.00 \\
14.19 \\
39.99 \\
99.17 \\
47.29\end{array}$ & $\begin{array}{l}\text { (Saleem et al. } \\
\text { 2019) }\end{array}$ & II & $\begin{array}{l}\text { China, N. } \\
\text { Africa, } \\
\text { S. Europe }\end{array}$ & N/A & $\begin{array}{l}\text { G.42; I.I.1-1a- } \\
\text { 1b; IV.C. 1; } \\
\text { V.A.29; } \\
\text { VI.C.78-78a. }\end{array}$ \\
\hline Cactaceae & $\begin{array}{l}\text { Opuntia microdasys } \\
\text { (Lehm.) Pfeiff. }\end{array}$ & $\begin{array}{l}\text { Kaktus bunny } \\
\text { ears }\end{array}$ & $\begin{array}{c}\text { MCF7 } \\
\text { HCT-15 } \\
\text { HeLa } \\
\text { HepG2 }\end{array}$ & Crude & $\begin{array}{c}>400 \\
97 \pm 1 \\
117 \pm 4 \\
238 \pm 5\end{array}$ & $\begin{array}{l}\text { (Chahdoura et } \\
\text { al. 2016) }\end{array}$ & II & N/A & $\begin{array}{l}\text { LC (Bár- } \\
\text { cenas } \\
\text { 2017) }\end{array}$ & $\begin{array}{l}\text { CA.B.6; } \\
\text { CB.B.2. }\end{array}$ \\
\hline Cactaceae & $\begin{array}{c}\text { Opuntia robusta J.C. } \\
\text { Wendl. }\end{array}$ & . Wheel cactus & $\begin{array}{r}\mathrm{HT}-29 \\
\mathrm{CaCo}-2\end{array}$ & Crude & N/A & $\begin{array}{l}\text { (Serra et al. } \\
\text { 2013) }\end{array}$ & $\begin{array}{c}\text { IV } \\
\text { Contains betasianin }\end{array}$ & N/A & $\begin{array}{l}\text { LC (Her- } \\
\text { nández et } \\
\text { al. 2017) }\end{array}$ & CA.C.1. \\
\hline Campanulaceae & $\begin{array}{l}\text { Lobelia laxiflora } \\
\text { Kunth }\end{array}$ & $\begin{array}{l}\text { Lobelia } \\
\text { meksiko }\end{array}$ & KB & Crude & 3.2 & $\begin{array}{l}\text { (Alonso- } \\
\text { Castro et al. } \\
\text { 2011) }\end{array}$ & I.D & Mexico & N/A & $\begin{array}{l}\text { I.K.8; } \\
\text { IV.A.80-80a- } \\
\text { 80b. }\end{array}$ \\
\hline Chloranthaceae & $\begin{array}{l}\text { Sarcandra glabra } \\
\text { (Thunb.) Nakai }\end{array}$ & $\begin{array}{c}\text { Bone-knitted } \\
\text { lotus }\end{array}$ & HL-60 & Crude & 58 & $\begin{array}{l}\text { (W. Li et al. } \\
\text { 2007) }\end{array}$ & II & $\begin{array}{l}\text { W. Java } \\
\text { Flores }\end{array}$ & N/A & $\begin{array}{l}\text { V.A.62-62a- } \\
\text { 62b, 63-63a; } \\
\text { V.A.67-67a. }\end{array}$ \\
\hline Celastraceae & $\begin{array}{c}\text { Catha edulis (Vahl) } \\
\text { Endl. }\end{array}$ & Khat & $\begin{array}{l}\text { MCF7 } \\
\text { A2780 } \\
\text { HT-29 }\end{array}$ & Crude & $\begin{array}{l}22.65 \pm 3.51 \\
20.97 \pm 5.03 \\
39.22 \pm 0.10\end{array}$ & $\begin{array}{l}\text { (Alsanosy et } \\
\text { al. 2020) }\end{array}$ & II & $\begin{array}{l}\text { Arabic, N. } \\
\text { Africa }\end{array}$ & $\begin{array}{l}\text { LC } \\
\text { (Hilton- } \\
\text { Taylor } \\
\text { 1998) }\end{array}$ & I.J.13. \\
\hline Cibotiaceae & $\begin{array}{l}\text { Cibotium barometz } \\
\text { (L.) J.Sm. }\end{array}$ & Paku simpai & $\mathrm{CaCo}-2$ & N/A & N/A & $\begin{array}{l}\text { (Q. Wu and } \\
\text { Yang, 2009) }\end{array}$ & $\begin{array}{c}\text { IV } \\
\text { Antiinflamation }\end{array}$ & N/A & N/A & PT.108, 160. \\
\hline
\end{tabular}




\begin{tabular}{|c|c|c|c|c|c|c|c|c|c|c|}
\hline Clusiaceae & $\begin{array}{c}\text { Calophyllum soulattr } \\
\text { Burm.f. }\end{array}$ & Bintangor & $\begin{array}{c}\text { SNU-1 } \\
\text { HeLa } \\
\text { NCI-H23 HepG2 } \\
\text { K-562 } \\
\text { Raji } \\
\text { LS-174T } \\
\text { SK-MEL-28 } \\
\text { IMR-32 }\end{array}$ & Subfraction & $\begin{array}{l}1.56 \\
2.18 \\
2.08 \\
2.86 \\
1.75 \\
2.02 \\
2.49 \\
1.45 \\
0.54\end{array}$ & $\begin{array}{c}\text { (Mah et al. } \\
\text { 2012) }\end{array}$ & $\begin{array}{l}\text { I.A. } \\
\text { Contains soulattrin, } \\
\text { caloxanthone } \mathrm{C}\end{array}$ & $\begin{array}{l}\text { Jambi } \\
\text { W. Java }\end{array}$ & $\begin{array}{l}\text { LC } \\
\text { (Steven } \\
1998)\end{array}$ & $\begin{array}{l}\text { IX.B.67; } \\
\text { IX.C. } 42 \text { a. }\end{array}$ \\
\hline Clusiaceae & Garcinia celebica $\mathrm{L}$. & $\begin{array}{l}\text { Seashore } \\
\text { Mangosteen }\end{array}$ & $\mathrm{MCF}$ & Crude & 87 & $\begin{array}{l}\text { (Subarnas et } \\
\text { al. 2012) }\end{array}$ & II & $\begin{array}{l}\text { Aceh, C. } \\
\text { Sulawesi }\end{array}$ & N/A & $\begin{array}{l}\text { IX.C.9; } \\
\text { VIII.C.93. }\end{array}$ \\
\hline Clusiaceae & $\begin{array}{l}\text { Garcinia dioica } \\
\text { Blume }\end{array}$ & Asam kandis & N/A & N/A & N/A & $\begin{array}{l}\text { (Hemshe-khar } \\
\text { et al. 2011) }\end{array}$ & $\begin{array}{c}\text { IV } \\
\text { Contains rubraxanthone }\end{array}$ & W. Java & N/A & IX.C.32-32a. \\
\hline Clusiaceae & $\begin{array}{l}\text { Garcinia dulcis } \\
\text { (Roxb.) Kurz }\end{array}$ & Mundu & HepG2 & Crude & $7.5 \pm 2.52$ & $\begin{array}{l}\text { (Abu Bakar et } \\
\text { al. 2015) }\end{array}$ & I.D & C. Sulawesi & $\begin{array}{l}\text { LC (BGCI } \\
\text { and IUCN } \\
2019)\end{array}$ & IX.C.55. \\
\hline Clusiaceae & $\begin{array}{c}\text { Garcinia lateriflora } \\
\text { Blume }\end{array}$ & Gamboge & HT-29 & Subfraction & 0.36 & $\begin{array}{l}\text { (Ren et al. } \\
\text { 2010) }\end{array}$ & I.B. Contains morellic acid & Aceh & N/A & IX.C.33. \\
\hline Clusiaceae & $\begin{array}{l}\text { Garcinia latissima } \\
\text { Miq. }\end{array}$ & Kandis & N/A & N/A & N/A & $\begin{array}{l}\text { (Imran et al. } \\
2019 ; \\
\text { Purbowati and } \\
\text { Ersam 2019) }\end{array}$ & $\begin{array}{c}\text { IV } \\
\text { Contains kaemferol }\end{array}$ & Papua & N/A & $\begin{array}{l}\text { VII.B.133- } \\
\text { 133a. }\end{array}$ \\
\hline Clusiaceae & $\begin{array}{l}\text { Garcinia rostrata } \\
\text { (Hassk.) Miq. }\end{array}$ & Lulai, loli & MCF7 & Crude & $65 \pm 40$ & $\begin{array}{l}\text { (Jabit et al. } \\
\text { 2009) }\end{array}$ & II & Bengkulu & N/A & IX.C.68. \\
\hline Clusiaceae & $\begin{array}{l}\text { Garcinia } \mathrm{x} \\
\text { mangostana } \mathrm{L} \text {. }\end{array}$ & Manggis & $\begin{array}{l}\text { MCF7 } \\
\text { A549 } \\
\text { HepG2 } \\
\text { CNE }\end{array}$ & Subfraction & $\begin{array}{l}2.93 \\
2.03 \\
1.78 \\
1.59\end{array}$ & $\begin{array}{l}\text { (Fu et al. } \\
\text { 2013) }\end{array}$ & $\begin{array}{c}\text { I.A } \\
\text { Contains garcinon C }\end{array}$ & W. Java & N/A & IX.C. $54,57$. \\
\hline Combretaceae & $\begin{array}{c}\text { Terminalia } \\
\text { calamansanay Rolfe }\end{array}$ & $\begin{array}{l}\text { Philippine } \\
\text { Almond }\end{array}$ & $\begin{array}{c}\text { HeLa } \\
\text { HepG2 } \\
\text { T24 } \\
\text { HL-60 }\end{array}$ & Subfraction & $\begin{array}{c}141.05 \\
96.85 \\
38.86 \\
24.11\end{array}$ & $\begin{array}{l}\text { (L.-G. Chen et } \\
\text { al. 2009) }\end{array}$ & $\begin{array}{c}\text { II } \\
\text { Contains Punicalagin, } \\
\text { Sanguiin H-4 }\end{array}$ & S. Sulawesi & $\begin{array}{l}\text { LC (BGCI } \\
\text { and IUCN, } \\
2019)\end{array}$ & VIII.B.98. \\
\hline Compositae & $\begin{array}{c}\text { Achillea millefolium } \\
\text { L. }\end{array}$ & $\begin{array}{l}\text { Yarrow, daun } \\
\text { seribu, tepus } \\
\text { sigung }\end{array}$ & $\begin{array}{l}\text { MIA-PaCa2 } \\
\text { PANC-1 }\end{array}$ & Crude & $\begin{array}{l}28.8 \pm 15.8 \\
\quad>100\end{array}$ & $\begin{array}{l}\text { (Mouhid et al. } \\
\text { 2018) }\end{array}$ & II & $\begin{array}{l}\text { C. Asia, } \\
\text { Europe }\end{array}$ & $\begin{array}{l}\text { LC (Maiz- } \\
\text { Tome } \\
\text { 2016) }\end{array}$ & $\begin{array}{l}\text { I.G.69; I.J.I.1; } \\
\text { III.D.12. }\end{array}$ \\
\hline Compositae & Achillea ptarmica $\mathrm{L}$. & $\begin{array}{l}\text { Sneezewort } \\
\text { yarrow }\end{array}$ & N/A & N/A & N/A & $\begin{array}{l}\text { ( Ee et al. } \\
\text { 2010; Althaus } \\
\text { et al. 2014) }\end{array}$ & $\begin{array}{c}\text { IV } \\
\text { Contains pellitorine }\end{array}$ & Japan & $\begin{array}{l}\text { LC (Bilz } \\
\text { 2013) }\end{array}$ & I.J.I.2; III.D.2. \\
\hline Compositae & $\begin{array}{c}\text { Eclipta prostrata }(\mathrm{L} .) \\
\text { L. }\end{array}$ & $\begin{array}{l}\text { Karichalai, } \\
\text { false daisy, } \\
\text { luwisa }\end{array}$ & HeLa & Subfraction & 50 & $\begin{array}{c}\text { (Kannabiran } \\
\text { and Khanna } \\
\text { 2009) }\end{array}$ & $\begin{array}{c}\text { II } \\
\text { Contains dayscyphin C }\end{array}$ & Africa & $\begin{array}{l}\text { LC (Lans- } \\
\text { down and } \\
\text { Beentje } \\
\text { H.J. 2017) }\end{array}$ & I.G.181. \\
\hline Compositae & $\begin{array}{l}\text { Gerbera jamesonii } \\
\text { Bolus ex Hook.f. }\end{array}$ & Gerbera & A549 & N/A & N/A & $\begin{array}{l}\text { (Agarwal et al. } \\
\text { 2014) }\end{array}$ & $\begin{array}{l}\text { IV. Antiproliferatif and } \\
\text { antimetastasis }\end{array}$ & S. Africa & N/A & $\begin{array}{l}\text { I.G.75; } \\
\text { III.D.10. }\end{array}$ \\
\hline
\end{tabular}




\begin{tabular}{|c|c|c|c|c|c|c|c|c|c|c|}
\hline Compositae & $\begin{array}{c}\text { Smallanthus } \\
\text { sonchifolius (Poepp.) } \\
\text { H.Rob }\end{array}$ & $\begin{array}{l}\text { Daun insulin, } \\
\text { yakon }\end{array}$ & HepG2 & Crude & $58.2 \pm 1.9$ & $\begin{array}{l}\text { (Myint et al. } \\
\text { 2019) }\end{array}$ & II & Japan & N/A & V.A.56. \\
\hline Compositae & $\begin{array}{l}\text { Taraxacum } \\
\text { campylodes } \\
\text { G.E.Haglund }\end{array}$ & Anddelion & MCF7 & Crude & 190.5 & $\begin{array}{l}\text { (Mu-hammed } \\
\text { et al. 2018) }\end{array}$ & III & Europe & N/A & I.G.78. \\
\hline Compositae & $\begin{array}{l}\text { Tithonia } \\
\text { diversifolia (Hemsl.) } \\
\text { A.Gray }\end{array}$ & $\begin{array}{l}\text { Bunga matahari } \\
\text { meksiko }\end{array}$ & $\mathrm{HeLa}$ & Crude & 3.38 & $\begin{array}{l}\text { (Arbiastutie } \\
\text { 2017) }\end{array}$ & I.D & C. America & N/A & I.K.50; III.D.6. \\
\hline Compositae & $\begin{array}{l}\text { Vernonia amygdalina } \\
\text { Delile }\end{array}$ & $\begin{array}{l}\text { Daun pahit, } \\
\text { daun afrika }\end{array}$ & $\begin{array}{c}\text { MCF7 } \\
\text { MDA-MB-231 }\end{array}$ & Crude & $\begin{array}{l}56 \\
46\end{array}$ & $\begin{array}{l}\text { (Wong et al. } \\
\text { 2013) }\end{array}$ & II & China & N/A & III.E.38-38a. \\
\hline Compositae & $\begin{array}{l}\text { Vernonia arborea } \\
\text { Buch. -Ham. }\end{array}$ & Merambung & $\begin{array}{c}\text { MCF7 } \\
\text { MDA-MB-231 } \\
\text { MCF10A }\end{array}$ & Subfraction & $\begin{array}{c}8.02 \\
6.13 \\
19.32\end{array}$ & $\begin{array}{l}\text { (Valkute et al. } \\
\text { 2018) }\end{array}$ & $\begin{array}{c}\text { II } \\
\text { Contains } \\
\text { (3R,3aS,6aR,8S,9aR,9bS)- } \\
\text { 8-Hydroxy-6,9- } \\
\text { dimethylene-3-(((R)-1- } \\
\text { (naph-thalen-1-yl)ethyl)- } \\
\text { amino)methyl)decahydroaz } \\
\text { uleno } \\
\text { [4,5-b] furan-2(3H)-one } \\
\text { and (3R,3aS, } \\
\text { 6aR,8S,9aR,9bS)-8- } \\
\text { Hydroxy-6,9-di-methylene- } \\
\text { 3-(((R)- } \\
\text { 1-(naphthalen-1- } \\
\text { yl)ethyl)amino)methyl)dec } \\
\text { ahydroazuleno [4,5-b] } \\
\text { furan-2(3H)-one }\end{array}$ & $\begin{array}{l}\text { W. Sumatra } \\
\text { W. Java } \\
\text { Jambi }\end{array}$ & N/A & $\begin{array}{l}\text { VII.C.3; } \\
\text { III.E. } 43,47 \text {; } \\
\text { VI.E.129; } \\
\text { VII.C. } 208 .\end{array}$ \\
\hline Cornaceae & $\begin{array}{l}\text { Alangium chinense } \\
\text { (Lour.) Harms }\end{array}$ & Kicareuh & HeLa & Crude & $>12.5$ & $\begin{array}{l}\text { (Fan et al. } \\
\text { 2017) }\end{array}$ & II & $\begin{array}{c}\text { China, India } \\
\text { Jambi } \\
\text { W. Java }\end{array}$ & N/A & $\begin{array}{c}\text { V.A.20; } \\
\text { VI.A.15-15a; } \\
\text { VI.E. 76; } \\
\text { VII.C. 193; } \\
\text { VII.B. 10-10a; }\end{array}$ \\
\hline Cornaceae & $\begin{array}{l}\text { Alangium javanicum } \\
\text { (Blume) Wangerin }\end{array}$ & Meranti putih & N/A & N/A & N/A & $\begin{array}{c}\text { (Pham et al. } \\
\text { 2005) }\end{array}$ & $\begin{array}{c}\text { IV. Contains javanisida and } \\
\text { alangisida }\end{array}$ & Lampung & $\begin{array}{c}\text { LC (World } \\
\text { Conser- } \\
\text { vation } \\
\text { Monito- } \\
\text { ring } \\
\text { Centre, } \\
1998)\end{array}$ & VI.A.50. \\
\hline
\end{tabular}




\begin{tabular}{|c|c|c|c|c|c|c|c|c|c|c|}
\hline Cornaceae & $\begin{array}{c}\text { Camptotecha } \\
\text { acuminata Decne. }\end{array}$ & Pohon bahagia & MDA-MB-435S & Subfraction & 0.74 & $\begin{array}{l}\text { (J. Zhang et al. } \\
\text { 2007; Lichota } \\
\text { and } \\
\text { Gwozdzin-ski } \\
\text { 2018) }\end{array}$ & $\begin{array}{c}\text { I.B } \\
\text { Contains camptothecin }\end{array}$ & N/A & N/A & IV.E.38; \\
\hline Costaceae & $\begin{array}{c}\text { Cheilocostus } \\
\text { speciosus (J.Koenig) } \\
\text { C.D.Specht }\end{array}$ & Crepe ginger & HepG2 & Crude & $13.87 \pm 1.4$ & $\begin{array}{l}\text { (Gheraibia et } \\
\text { al. 2020) }\end{array}$ & II & W. Java & N/A & I.K.142. \\
\hline Crassulaceae & $\begin{array}{c}\text { Kalanchoe } \\
\text { beharensis Drake }\end{array}$ & $\begin{array}{c}\text { Elephant's ear } \\
\text { kalanchoe, } \\
\text { kalanchu }\end{array}$ & $\begin{array}{l}\text { HL-60 } \\
\text { HL-60R }\end{array}$ & Essential oil & $\begin{array}{l}25.0 \pm 0.6 \\
36.5 \pm 0.3\end{array}$ & $\begin{array}{l}\text { (Poma et al. } \\
\text { 2019) }\end{array}$ & II & N/A & $\begin{array}{c}\text { VU } \\
\text { (Rabehevit } \\
\text { ra 2019) }\end{array}$ & VI.D.62, 144. \\
\hline Cupressaceae & $\begin{array}{c}\text { Cryptomeria } \\
\text { japonica (Thunb. ex } \\
\text { L.f) D.Don }\end{array}$ & $\begin{array}{l}\text { Sugi, Japanese } \\
\text { cedar }\end{array}$ & KB & Subfraction & 3.43 & $\begin{array}{l}\text { (C.-C. Chen et } \\
\text { al. 2010) }\end{array}$ & $\begin{array}{c}\text { I.B } \\
\text { Contains crytotrione }\end{array}$ & $\begin{array}{l}\text { China, Japan } \\
\text { Japan }\end{array}$ & $\begin{array}{l}\text { NT } \\
\text { (Thomas } \\
\text { et al. } \\
\text { 2013) }\end{array}$ & $\begin{array}{l}\text { I.J.15-15a; } \\
\text { I.K.201-201a; } \\
\text { II.B. 11; } \\
\text { III.B.12-12a- } \\
\text { 12b; XII.B.22; } \\
\text { XIV.B.22-22a- } \\
\text { 22b; III.C.58- } \\
\text { 58a-58b. }\end{array}$ \\
\hline Cupressaceae & $\begin{array}{l}\text { Cupressus lusitanica } \\
\text { Mill. }\end{array}$ & $\begin{array}{l}\text { Cemara } \\
\text { meksiko }\end{array}$ & $\begin{array}{c}\text { THP-1 } \\
\text { DU-145 } \\
\text { HeLa } \\
\text { MCF7 } \\
\text { HepG2 }\end{array}$ & Crude & $\begin{array}{l}60.8 \pm 5.8 \\
74.6 \pm 6.1 \\
83.1 \pm 6.7 \\
13.1 \pm 0.9 \\
93.8 \pm 7.4\end{array}$ & $\begin{array}{l}\text { (Mbaveng et } \\
\text { al. 2011) }\end{array}$ & II & $\begin{array}{l}\text { Guatema-la, } \\
\text { Mexico }\end{array}$ & N/A & $\begin{array}{l}\text { I.J.4; III.E.3; } \\
\text { VI.A.25; } \\
\text { VI.E.6-6a. }\end{array}$ \\
\hline Cupressaceae & $\begin{array}{c}\text { Cupressus } \\
\text { sempervirens } \mathrm{L} .\end{array}$ & Cemara italia & $\begin{array}{l}\text { NBA-4 } \\
\text { HL-60 } \\
\text { EACC } \\
\text { C32 }\end{array}$ & Essential oil & $\begin{array}{l}333.79 \\
365.41 \\
372.43 \\
104.90\end{array}$ & $\begin{array}{c}\text { (Loizzo et al. } \\
\text { 2008; (Fayed } \\
\text { 2015) }\end{array}$ & III & $\begin{array}{l}\text { Europe } \\
\text { N. India, S. } \\
\text { Europe, W. } \\
\quad \text { Asia }\end{array}$ & $\begin{array}{l}\text { LC (Farjon } \\
\text { 2013) }\end{array}$ & $\begin{array}{l}\text { III.C.7; V.B.1- } \\
\text { 1a, 5a; VI.A.1. }\end{array}$ \\
\hline Cupressaceae & $\begin{array}{c}\text { Juniperus chinensis } \\
\text { L. }\end{array}$ & Cemara cina & HT-29 & Subfraction & 14.05 & $\begin{array}{l}\text { (Kwon et al. } \\
2010)\end{array}$ & II & $\begin{array}{l}\text { China, } \\
\text { Himalaya }\end{array}$ & $\begin{array}{l}\text { LC (Farjon } \\
2013)\end{array}$ & $\begin{array}{c}\text { II.A.53; } \\
\text { III.C.49-49a- } \\
\text { 49b; V.C.16- } \\
\text { 16a-16b; VI.A. } \\
\text { 3-3a }\end{array}$ \\
\hline Cupressaceae & $\begin{array}{l}\text { Juniperus procera } \\
\text { Hochst. ex Endl. }\end{array}$ & Cedar afrika & $\mathrm{CaCo}-2$ & Crude & 8.8 & (Ganash 2019) & I.D & Kenya & $\begin{array}{l}\text { LC (Farjon } \\
\text { 2013) }\end{array}$ & $\begin{array}{l}\text { I.D.44; I.G.39- } \\
\text { 39a-39b; } \\
\text { II.A.3; } \\
\text { III.C.130- } \\
\text { 130a; XI.A. } \\
\text { 20-20a-20b. }\end{array}$ \\
\hline Cupressaceae & $\begin{array}{c}\text { Juniperus } \\
\text { procumbens (Siebold } \\
\text { ex Endl.) Miq. }\end{array}$ & $\begin{array}{l}\text { Japanese } \\
\text { juniper }\end{array}$ & N/A & N/A & N/A & $\begin{array}{l}\text { (Kusari et al. } \\
\text { 2011; Tavares } \\
\text { and Seca } \\
\text { 2018) }\end{array}$ & $\begin{array}{c}\text { IV } \\
\begin{array}{c}\text { Contains deoxypodophyllo- } \\
\text { toxin }\end{array}\end{array}$ & $\begin{array}{l}\text { W \&S. } \\
\text { Korea, } \\
\text { S. Japan }\end{array}$ & $\begin{array}{l}\text { LC (Farjon } \\
\text { and Carter } \\
\text { 2013) }\end{array}$ & I.G.12. \\
\hline
\end{tabular}




\begin{tabular}{|c|c|c|c|c|c|c|c|c|c|c|}
\hline Cupressaceae & $\begin{array}{l}\text { Juniperus virginiana } \\
\text { L. }\end{array}$ & $\begin{array}{l}\text { Red juniper, } \\
\text { cemara angina } \\
\text { kerucut }\end{array}$ & $\begin{array}{c}\text { HepG2 } \\
\text { Hep3B } \\
\text { A549 } \\
\text { MCF7 } \\
\text { MDA-MB-231 }\end{array}$ & Essential oil & $\begin{array}{r}11.18 \pm 0.71 \\
3.02 \pm 0.03 \\
1.79 \pm 0.07 \\
3.99 \pm 0.13 \\
4.32 \pm 0.05\end{array}$ & $\begin{array}{l}\text { (Yen et al. } \\
\text { 2012) }\end{array}$ & I.C & N. America & $\begin{array}{l}\text { LC (Farjon } \\
\text { 2013) }\end{array}$ & $\begin{array}{l}\text { IV.F.10; } \\
\text { VIII.A.7. }\end{array}$ \\
\hline Cupressaceae & $\begin{array}{l}\text { Platycladus orientali: } \\
\text { (L.) Franco }\end{array}$ & Cemara kipas & $\begin{array}{c}\text { A549 } \\
\text { HepG2 } \\
\text { MCF7 } \\
\text { NIH3T3 }\end{array}$ & Subfraction & $\begin{array}{c}9.2 \\
11.4 \\
10.4 \\
>20\end{array}$ & $\begin{array}{l}\text { (Selim et al. } \\
\text { 2020) }\end{array}$ & $\begin{array}{c}\text { II } \\
\text { Contains apigenin 8- } \\
\text { gernayl-40-O-a-gluco } \\
\text { pyranoside }\end{array}$ & $\begin{array}{l}\text { N.W. China } \\
\text { to Korea }\end{array}$ & $\begin{array}{l}\text { NT } \\
\text { (Farjon } \\
2013 \text { ) }\end{array}$ & $\begin{array}{c}\text { V.E.21-21a; } \\
\text { V.C.13-13c; } \\
\text { VI.A.4-4a; } \\
\text { VI.D.7-7a; } \\
\text { XII.A.9; } \\
\text { XIV.A.45-45a- } \\
\text { 45b; } \\
\text { XIV.B.17-17a, } \\
\text { 41. }\end{array}$ \\
\hline Cupressaceae & Thuja occidentalis L. & White cedar & A549 & Subfraction & $7.6 \pm 0.05$ & $\begin{array}{l}\text { (Mukherjee et } \\
\text { al. 2014) }\end{array}$ & $\begin{array}{c}\text { II } \\
\text { Contains flavonol }\end{array}$ & Hungaria & $\begin{array}{l}\text { LC (Farjon } \\
\text { 2013) }\end{array}$ & $\begin{array}{l}\text { II.A.52; } \\
\text { XX.B.19-19a. }\end{array}$ \\
\hline Cupressaceae & $\begin{array}{l}\text { Thuja standishii } \\
\text { (Gord.) Carr }\end{array}$ & Cemara jepang & N/A & N/A & N/A & (Tanaka 2000) & $\begin{array}{c}\text { IV } \\
\text { In vitro study, Contains } \\
\text { labande diterpenoids }\end{array}$ & Japan & $\begin{array}{l}\text { NT (Carter } \\
\text { and Farjon } \\
\text { 2013) }\end{array}$ & V.C.11. \\
\hline Cupressaceae & $\begin{array}{l}\text { Thujopsis dolabrata } \\
\text { (L.f.) Siebold and } \\
\text { Zucc. }\end{array}$ & Hiba, asunaro & MKN-45 & Essential oil & 0.002 & $\begin{array}{l}\text { (Nagata et al. } \\
\text { 2016) }\end{array}$ & I.D & Japan & $\begin{array}{l}\text { LC (Carter } \\
\text { 2013) }\end{array}$ & $\begin{array}{l}\text { I.I.12; } \\
\text { III.E.27-27a; } \\
\text { IV.E. } 27 .\end{array}$ \\
\hline Cyperaceae & $\begin{array}{c}\text { Cyperus alternifolius } \\
\text { L. }\end{array}$ & $\begin{array}{l}\text { Umbrella } \\
\text { papyrus }\end{array}$ & N/A & N/A & N/A & $\begin{array}{l}\text { (Al-Gara'awi } \\
\text { et al. 2019) }\end{array}$ & $\begin{array}{l}\text { IV. Contains 2,7-Diphenyl- } \\
\text { 1,6- } \\
\text { dioxopyridazino[4,5:2',3’] } \\
\text { pyrrolo[4',5'-d]pyridazi } \\
\text { and Methyl 6- } \\
\text { oxoheptanoate, and others }\end{array}$ & W. Sumatra & $\begin{array}{c}\text { LC } \\
\text { (Lansd- } \\
\text { own 2018) }\end{array}$ & X.A.63. \\
\hline Dilleniaceae & $\begin{array}{c}\text { Dillenia } \\
\text { philippinensis } \text { Rolfe }\end{array}$ & Katmon & $\begin{array}{c}\text { MCF7 } \\
\text { HCT-116 } \\
\text { HCT-15 } \\
\text { HCT-15/Dox }\end{array}$ & Crude & $\begin{array}{c}11.92 \pm 1.91 \\
14.23 \pm 0.65 \\
9.13 \pm 1.45 \\
23.11 \pm 0.67\end{array}$ & $\begin{array}{l}\text { (Dante et al. } \\
\text { 2019) }\end{array}$ & I.C & Philippines & $\begin{array}{c}\text { NT } \\
\text { (Energy } \\
\text { Develop- } \\
\text { ment } \\
\text { Corpo- } \\
\text { ration } \\
2020)\end{array}$ & $\begin{array}{l}\text { I.A.71-71a, 96; } \\
\text { I.D.76-76a; } \\
\text { II.B. 13-13a- } \\
\text { 13b. }\end{array}$ \\
\hline Dilleniaceae & $\begin{array}{l}\text { Dillenia serrata } \\
\text { Thunb. }\end{array}$ & Simpur & N/A & N/A & N/A & $\begin{array}{l}\text { ( Nassar et al. } \\
\text { 2012; Jalil et } \\
\text { al. 2015) }\end{array}$ & $\begin{array}{c}\text { IV } \\
\text { Contains oetjapic acid and } \\
\text { betulinic acid }\end{array}$ & $\begin{array}{l}\text { C. Sulawesi } \\
\text { Sulawesi } \\
\text { W. Java }\end{array}$ & $\begin{array}{l}\text { LC (IUCN } \\
\text { and BGCI } \\
2019)\end{array}$ & $\begin{array}{l}\text { VIII.C.66; } \\
\text { VI.D.193- } \\
\text { 193a; VI.D. } \\
\text { 166-166a. }\end{array}$ \\
\hline Dioscoreaceae & $\begin{array}{l}\text { Dioscorea } \\
\text { bulbifera } \mathrm{L} \text {. }\end{array}$ & $\begin{array}{l}\text { Gadung, } \\
\text { gembolo }\end{array}$ & $\begin{array}{c}\text { CCRF-CEM } \\
\text { MDA-MB-231 } \\
\text { HCT-116 } \\
\text { (p53+/+) }\end{array}$ & Crude & $\begin{array}{l}19.77 \pm 2.22 \\
33.17 \pm 2.91 \\
36.14 \pm 2.37\end{array}$ & $\begin{array}{l}\text { (Kuete et al. } \\
\text { 2013) }\end{array}$ & II & N/A & N/A & CL.12. \\
\hline
\end{tabular}




\begin{tabular}{|c|c|c|c|c|c|c|c|c|c|c|}
\hline Dioscoreaceae & $\begin{array}{c}\text { Iacca chantrierl } \\
\text { Andre }\end{array}$ & $\begin{array}{c}\text { Bunga } \\
\text { kelelawar hitam }\end{array}$ & $\begin{array}{l}\text { HCI-1 IO HepU2 } \\
\text { BGC-823 } \\
\text { NCI-H1650 } \\
\text { A2780 }\end{array}$ & Subtraction & $\begin{array}{l}0.81 \\
0.79 \\
0.92 \\
2.15 \\
0.75\end{array}$ & (N1 et al. 2U1J) & $\begin{array}{c}\text { I.A } \\
\text { Contains taccalonolide B }\end{array}$ & Acen & N/A & 1.b.68-6૪a. \\
\hline Dipterocarpaceae & $\begin{array}{l}\text { Shorea javanica } \\
\text { Koord. and Valeton }\end{array}$ & Damar & $\begin{array}{l}\text { HL-60 } \\
\text { CRL1579 }\end{array}$ & Subfraction & $\begin{array}{l}4.7 \\
7.5\end{array}$ & $\begin{array}{l}\text { (Ukiya et al. } \\
\text { 2010) }\end{array}$ & $\begin{array}{c}\text { II } \\
\text { Contains Dammarenoyl-1- } \\
\text { phenylalanine }\end{array}$ & Lampung & $\begin{array}{l}\text { EN (Bars- } \\
\text { tow 2018) }\end{array}$ & $\begin{array}{l}\text { IX.C.52-52a, } \\
\text { 56-56a, 61- } \\
\text { 61a. }\end{array}$ \\
\hline Dipterocarpaceae & $\begin{array}{l}\text { Shorea platyclados } \\
\text { Slooten ex Endert }\end{array}$ & Meranti merah & N/A & N/A & N/A & $\begin{array}{l}\text { (Saroyobudiyo } \\
\text { no and Aisyah } \\
\text { 2006; Honari } \\
\text { et al. 2019) }\end{array}$ & $\begin{array}{c}\text { IV } \\
\text { Contains resveratrol }\end{array}$ & Banten & $\begin{array}{c}\text { EN } \\
\text { (Ashton } \\
1998 \text { ) }\end{array}$ & $\begin{array}{l}\text { IX.C. } 45-45 a- \\
\quad 45 b .\end{array}$ \\
\hline Ebenaceae & $\begin{array}{c}\text { Diospyros celebica } \\
\text { Bakh. }\end{array}$ & Black ebony & N/A & N/A & N/A & $\begin{array}{l}\text { (Mallava- } \\
\text { dhani et al. } \\
\text { 1998) }\end{array}$ & $\begin{array}{c}\text { IV } \\
\text { Contains plumbagin }\end{array}$ & $\begin{array}{l}\text { Sulawesi } \\
\text { W. Java }\end{array}$ & $\begin{array}{l}\text { VU (World } \\
\text { Conser- } \\
\text { vation } \\
\text { Monitor-ing } \\
\text { Centre } \\
1998)\end{array}$ & $\begin{array}{l}\text { III.D. } 38,54 ; \\
\text { III.D.41, 43. }\end{array}$ \\
\hline Ebenaceae & $\begin{array}{l}\text { Diospyros discolor } \\
\text { Willd. }\end{array}$ & $\begin{array}{l}\text { Buah bisbul, } \\
\text { samolo, } \\
\text { butterfruit }\end{array}$ & $\begin{array}{l}\text { HT-29 } \\
\text { J5 } \\
\text { A549 }\end{array}$ & Subfraction & $\begin{array}{c}0.8 \\
12.1 \\
10.8\end{array}$ & $\begin{array}{l}\text { (Su et al. } \\
\text { 2015) }\end{array}$ & $\begin{array}{c}\text { I.A } \\
\text { Contains } \alpha \text {-Cadinol }\end{array}$ & W. Java & N/A & $\begin{array}{l}\text { IX.B.151- } \\
\text { 151a-151c. }\end{array}$ \\
\hline Ebenaceae & Diospyros kaki L.f. & $\begin{array}{l}\text { Kesemek, } \\
\text { persimon }\end{array}$ & $\begin{array}{l}\text { A549 } \\
\text { HepG2 } \\
\text { HT-29 }\end{array}$ & Subfraction & $\begin{array}{c}6.04 \\
13.2 \\
11.76\end{array}$ & $\begin{array}{l}\text { (G. Chen et al. } \\
\text { 2007) }\end{array}$ & $\begin{array}{c}\text { II } \\
\text { Contains kakisaponin A }\end{array}$ & China, Japan & $\begin{array}{l}\text { LC (Zhao, } \\
\text { Yu, BGCI } \\
\text { and IUCN, } \\
2019)\end{array}$ & $\begin{array}{l}\text { I.A.23-23a; } \\
\text { III.D.37-37a, } \\
\text { 39-39a-39b, } \\
\quad 46,48 .\end{array}$ \\
\hline Elaeocarpaceae & $\begin{array}{c}\text { Elaeocarpus } \\
\text { densiflorus Knuth }\end{array}$ & N/A & N/A & N/A & N/A & $\begin{array}{l}\text { (Shah et al. } \\
\text { 2011) }\end{array}$ & $\begin{array}{c}\text { IV } \\
\text { Contains elaeocarpidin }\end{array}$ & Papua & N/A & $\begin{array}{l}\text { VII.C.328- } \\
\text { 328a-328b, } \\
\text { 457-457a- } \\
\text { 457b. }\end{array}$ \\
\hline Elaeocarpaceae & $\begin{array}{c}\text { Elaeocarpus glaber } \\
\text { Blume }\end{array}$ & Bengkinang & $\mathrm{MCF}$ & Crude & 297 & $\begin{array}{l}\text { (Subarnas et } \\
\text { al. 2012) }\end{array}$ & III & Jambi & N/A & IX.B.33. \\
\hline Elaeocarpaceae & $\begin{array}{c}\text { Elaeocarpus } \\
\text { petiolatus (Jacq.) } \\
\text { Wall. }\end{array}$ & Derumun babi & $\begin{array}{c}\text { MDA-MB-468 } \\
\text { MDA-MB-231 } \\
\text { MCF7 } \\
\text { SKBR3 } \\
\text { SW-480 }\end{array}$ & Subfraction & N/A & (Cho, 2019) & $\begin{array}{c}\text { IV } \\
\text { Contains cucurbitacin }\end{array}$ & $\begin{array}{l}\text { S. Sumatra } \\
\text { Jambi } \\
\text { Lampung } \\
\text { Bengkulu }\end{array}$ & $\begin{array}{l}\text { LC (Zhao, } \\
\text { Yu, BGCI } \\
\text { and IUCN, } \\
2019)\end{array}$ & $\begin{array}{l}\text { VII.C.384; } \\
\text { IX.B.65; } \\
\text { IV.A.141- } \\
\quad \text { 141a; } \\
\text { IV.A.142 }\end{array}$ \\
\hline Elaeocarpaceae & $\begin{array}{l}\text { Elaeocarpus } \\
\text { reticulatus } \mathrm{Sm} .\end{array}$ & Blueberry ash & BxPC-3 & Crude & 22.14 & $\begin{array}{l}\text { (Turner et al. } \\
2020 \text { ) }\end{array}$ & II & W. Sumatra & N/A & $\begin{array}{l}\text { VII.C.353- } \\
\text { 353a. }\end{array}$ \\
\hline Elaeocarpaceae & $\begin{array}{c}\text { Elaeocarpus serratus } \\
\text { L. }\end{array}$ & Ceylon olive & N/A & N/A & N/A & $\begin{array}{l}\text { (Geetha et al. } \\
\text { 2013) }\end{array}$ & $\begin{array}{c}\text { IV } \\
\text { Contains farnesol }\end{array}$ & W. Sumatra & N/A & VII.C.410. \\
\hline Elaeocarpaceae & $\begin{array}{c}\text { Elaeocarpus } \\
\text { sylvestris (Lour.) } \\
\text { Poir. }\end{array}$ & $\begin{array}{l}\text { The woodland } \\
\text { elaeocarpus }\end{array}$ & N/A & N/A & N/A & $\begin{array}{l}\text { (L. Wu et al. } \\
\text { 2019) }\end{array}$ & $\begin{array}{c}\text { IV } \\
\text { Contains brevifolin }\end{array}$ & W. Java & $\begin{array}{l}\text { LC (BGCI } \\
\text { and IUCN, } \\
2019)\end{array}$ & VII.C.249. \\
\hline
\end{tabular}




\begin{tabular}{|c|c|c|c|c|c|c|c|c|c|c|}
\hline Ericaceae & $\begin{array}{l}\text { Vaccinium } \\
\text { varingiaefolium } \\
\text { (Blume) Miq }\end{array}$ & Cantigi & $\begin{array}{l}\text { T-47D } \\
\text { MCF7 }\end{array}$ & Crude & $\begin{array}{l}75.23 \\
88.89\end{array}$ & $\begin{array}{c}\text { (Kosasih et al. } \\
\text { 2019) }\end{array}$ & II & $\begin{array}{l}\text { Malesia } \\
\text { W.Java }\end{array}$ & N/A & $\begin{array}{l}\text { VII.C.95-95a; } \\
\text { I.G.194. }\end{array}$ \\
\hline Euphorbiaceae & $\begin{array}{l}\text { Acalypha hispida } \\
\text { Burm.f. }\end{array}$ & $\begin{array}{l}\text { Red hot cat's } \\
\text { tail }\end{array}$ & N/A & Subfraction & N/A & $\begin{array}{c}\text { (Evanjelene } \\
\text { and Karthiga } \\
\text { 2018) }\end{array}$ & $\begin{array}{c}\text { IV } \\
\text { Studi in silico, Contains 5- } \\
\text { Hydroxymethylfurfural and } \\
\text { Beta-Amyrin }\end{array}$ & New Guinea & N/A & $\begin{array}{l}\text { IV.A.83-83a; } \\
\text { VI.D.6-6a. }\end{array}$ \\
\hline Euphorbiaceae & $\begin{array}{c}\text { Acalypha wilkesiana } \\
\text { Müll.Arg. }\end{array}$ & $\begin{array}{l}\text { Akalipa, daun } \\
\text { renda }\end{array}$ & $\begin{array}{l}\text { U87-MG } \\
\text { A549 }\end{array}$ & Crude & $\begin{array}{l}28.03 \pm 6.44 \\
89.63 \pm 2.12\end{array}$ & $\begin{array}{l}\text { (Lim et al. } \\
\text { 2011) }\end{array}$ & II & Fiji Isl. & N/A & $\begin{array}{l}\text { II.E.18-18a; } \\
\text { VI.C.40-40a }\end{array}$ \\
\hline Euphorbiaceae & $\begin{array}{l}\text { Aleurites moluccanus } \\
\text { (L.) Willd. }\end{array}$ & Kemiri & N/A & Subfraction & N/A & $\begin{array}{l}\text { ((Monks et al. } \\
\text { 2002); Tian et } \\
\text { al. 2019) }\end{array}$ & $\begin{array}{c}\text { IV } \\
\text { Contains coumarin } \\
\text { scopoletin }\end{array}$ & C. Sulawesi & $\begin{array}{l}\text { LC (Rivers } \\
\text { et al., } \\
\text { 2017) }\end{array}$ & XIX.A.33, 34. \\
\hline Euphorbiaceae & $\begin{array}{l}\text { Croton argyratus } \\
\text { Blume }\end{array}$ & Calik angin & LU-1 & Crude & 1.7 & $\begin{array}{l}\text { (Horgen et al. } \\
\text { 2001; Nath et } \\
\text { al. 2013) }\end{array}$ & 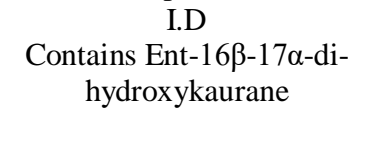 & $\begin{array}{l}\text { Aceh } \\
\text { W. Java } \\
\text { W. Sumatra }\end{array}$ & $\begin{array}{l}\text { LC (Old- } \\
\text { field, } \\
2020)\end{array}$ & $\begin{array}{l}\text { VIII.B.279a; } \\
\text { VIII.A.46; } \\
\text { VIII.B.104; } \\
\text { VIII.B.323a. }\end{array}$ \\
\hline Euphorbiaceae & $\begin{array}{l}\text { Euphorbia milii Des } \\
\text { Moul. }\end{array}$ & $\begin{array}{l}\text { Pakis giwang, } \\
\text { bunga } \\
\text { euphorbia }\end{array}$ & N/A & Subfraction & N/A & $\begin{array}{l}\text { (Kamurthy and } \\
\text { Dontha 2015; } \\
\text { Liao et al. } \\
\text { 2018) }\end{array}$ & $\begin{array}{c}\text { IV } \\
\text { Contains taraxerol and } \\
\text { quercetin }\end{array}$ & Madagas-car & $\begin{array}{c}\text { LC } \\
\text { (Razana- } \\
\text { jato, 2020) }\end{array}$ & III.C.1. \\
\hline Euphorbiaceae & $\begin{array}{c}\text { Euphorbia } \\
\text { pulcherrima Willd. ex } \\
\text { Klotzsch }\end{array}$ & Poinsettia & Ehrlich ascites & Subfraction & 3.32 & $\begin{array}{l}\text { (Smith- } \\
\text { Kielland et al. } \\
\text { 1996) }\end{array}$ & $\begin{array}{c}\text { I.B } \\
\text { Contains 9,19-cycloart-23- } \\
\text { ene-3J1,25-diol }\end{array}$ & Mexico & $\begin{array}{l}\text { LC (BGCI } \\
\text { and IUCN, } \\
\text { 2019) }\end{array}$ & $\begin{array}{c}\text { I.D.42; I.K.77- } \\
\text { 77a, 78-78b- } \\
\text { 78c; VI.C.33- } \\
\text { 33a-33b; } \\
\text { XI.A.6 }\end{array}$ \\
\hline Euphorbiaceae & $\begin{array}{c}\text { Jatropha } \\
\text { gossypiifolia } \mathrm{L} .\end{array}$ & Jarak merah & $\begin{array}{l}\text { HepG2-1886 } \\
\text { WIDR } \\
\text { HeLa } \\
\text { AGS }\end{array}$ & Subfraction & $\begin{array}{l}0.99 \\
2.79 \\
1.60 \\
0.78\end{array}$ & $\begin{array}{l}\text { (Asep et al. } \\
\text { 2017) }\end{array}$ & $\begin{array}{c}\text { I.A } \\
\text { Contains jatrophone }\end{array}$ & $\begin{array}{c}\text { S. E. } \\
\text { Sulawesi }\end{array}$ & $\begin{array}{c}\text { LC } \\
\text { (BGCI) } \\
\text { and IUCN, } \\
\text { 2019) }\end{array}$ & VIII.C.28. \\
\hline Euphorbiaceae & $\begin{array}{c}\text { Macaranga } \\
\text { rhizinoides (Blume) } \\
\text { Müll.Arg. }\end{array}$ & Awu & P388 & Subfraction & 4.97 & $\begin{array}{l}\text { (Tanjung et al. } \\
\text { 2010) }\end{array}$ & $\begin{array}{c}\text { II } \\
\text { Contains macarhizinoidins } \\
\text { A and B }\end{array}$ & Java & N/A & VII.C.3-3a. \\
\hline Euphorbiaceae & $\begin{array}{l}\text { Macaranga tanarius } \mathrm{I} \\
\text { (L.) Müll.Arg. }\end{array}$ & Parasol leaf tree & $\begin{array}{l}\mathrm{U} 87 \\
\mathrm{~A} 549\end{array}$ & Subfraction & $\begin{array}{c}0.0144 \\
0.09\end{array}$ & $\begin{array}{l}\text { (Péresse et al. } \\
\text { 2017) }\end{array}$ & $\begin{array}{c}\text { I.B } \\
\text { Contains vedelianin }\end{array}$ & W. Sumatra & N/A & $\begin{array}{l}\text { VII.C.341- } \\
\text { 341a; } \\
\text { XIX.A.29-29a- } \\
\text { 29b, } 31\end{array}$ \\
\hline Euphorbiaceae & $\begin{array}{l}\text { Macaranga triloba } \\
\text { (Thunb.) Müll.Arg. }\end{array}$ & Mahang damar & Hepa 1c1c7 & Subfraction & N/A & $\begin{array}{l}\text { (Jang et al. } \\
\text { 2004) }\end{array}$ & $\begin{array}{c}\text { IV } \\
\text { COX-1 and COX-2 } \\
\text { inhibitor, Contains } \\
\text { 3,7,3',4'- } \\
\text { tetramethylquercetin and } \\
\text { 3,7-dimethylquercetin }\end{array}$ & W. Java & N/A & XVIII.A.26. \\
\hline
\end{tabular}




\begin{tabular}{|c|c|c|c|c|c|c|c|c|c|c|}
\hline Equisetaceae & $\begin{array}{c}\text { Equisetum } \\
\text { ramosissimum Desf. }\end{array}$ & $\begin{array}{l}\text { Branched } \\
\text { Horsetail }\end{array}$ & $\begin{array}{c}\text { A375 } \\
\text { A375.S2 } \\
\text { A2058 }\end{array}$ & Crude & N/A & $\begin{array}{l}\text { (P.-H. Li et al. } \\
\text { 2016) }\end{array}$ & $\begin{array}{c}\text { IV } \\
\text { Melanoma inhibitor }\end{array}$ & N/A & $\begin{array}{l}\text { LC (Lans- } \\
\text { down, } \\
2018)\end{array}$ & PT.169. \\
\hline Fagaceae & $\begin{array}{l}\text { Quercus acuta } \\
\text { Thunb. }\end{array}$ & $\begin{array}{c}\text { Japanese green } \\
\text { oak }\end{array}$ & N/A & Subfraction & N/A & $\begin{array}{l}\text { ( Jong et al. } \\
\text { 2012; Huang } \\
\text { et al. 2019) }\end{array}$ & $\begin{array}{c}\text { IV } \\
\text { Contains chlorogenic acid }\end{array}$ & Japan & $\begin{array}{l}\text { LC (BGCI } \\
\text { and IUCN, } \\
\text { 2019) }\end{array}$ & $\begin{array}{l}\text { XIII.A.36; } \\
\text { XIII.B.55. }\end{array}$ \\
\hline Gnetaceae & Gnetum gnemon L. & Melinjo & P388 & Subfraction & 25.5 & $\begin{array}{l}\text { (Cahyana and } \\
\text { Ardiansah } \\
\text { 2016) }\end{array}$ & $\begin{array}{l}\text { II. Contains gnetol and (+)- } \\
\text { lirioresinol B }\end{array}$ & N/A & $\begin{array}{l}\text { LC } \\
\text { (Baloch, } \\
\text { 2011) }\end{array}$ & IX.A.14. \\
\hline Hernandiaceae & $\begin{array}{c}\text { Hernandia } \\
\text { nymphaeifolia } \\
\text { (J.Presl) Kubitzki }\end{array}$ & $\begin{array}{l}\text { Kampis } \\
\text { tiongkok }\end{array}$ & $\begin{array}{l}\text { KKU-M156 } \\
\text { HepG2 }\end{array}$ & Subfraction & $\begin{array}{l}2.08 \\
1.68\end{array}$ & $\begin{array}{l}\text { (Suthiwong et } \\
\text { al. 2018) }\end{array}$ & $\begin{array}{c}\text { I.B. Contains } \beta \text { - } \\
\text { apopicropodo-phyllin, } \\
\text { dehydro-podophyllotoxin, } \\
\text { deoxypodorhizone, and (-)- } \\
\text { maculatin }\end{array}$ & Papua & N/A & $\begin{array}{l}\text { VII.C. } 142- \\
142 \mathrm{a}, 143- \\
143 \mathrm{a} .\end{array}$ \\
\hline Hydrangeaceae & $\begin{array}{l}\text { Dichroa febrifuga } \\
\text { Lour. }\end{array}$ & Hidrangea & $\begin{array}{c}\text { MCF7 } \\
\text { MDA-MB-231 }\end{array}$ & Crude & $\begin{array}{l}0.08 \\
0.08\end{array}$ & $\begin{array}{l}\text { (Jin et al. } \\
\text { 2014) }\end{array}$ & $\begin{array}{c}\text { I.B } \\
\text { Contains halofuginone }\end{array}$ & $\begin{array}{l}\text { E. Asia, } \\
\text { Himalaya }\end{array}$ & N/A & $\begin{array}{l}\text { IV.D.12-12a; } \\
\text { XII.A. 18-18a. }\end{array}$ \\
\hline Hypericaceae & $\begin{array}{c}\text { Cratoxylum } \\
\text { formosum (Jacq.) } \\
\text { Benth. and Hook.f. ex } \\
\text { Dyer }\end{array}$ & Butun & $\begin{array}{c}\mathrm{HeLa} \\
\mathrm{SiHa} \\
\mathrm{C}-33 \mathrm{~A}\end{array}$ & Crude & $\begin{array}{r}143.18 \pm 13 \\
106.45 \pm 16 \\
130.95 \pm 3.8\end{array}$ & $\begin{array}{l}\text { (Promraksa et } \\
\text { al. 2015) }\end{array}$ & III & Bengkulu & $\begin{array}{l}\text { LC (World } \\
\text { Conser- } \\
\text { vation } \\
\text { Monitor- } \\
\text { ing Centre, } \\
\text { 1998) }\end{array}$ & IX.B.106. \\
\hline Hypericaceae & $\begin{array}{c}\text { Hypericum } \\
\text { oblongifolium Choisy }\end{array}$ & $\begin{array}{l}\text { Penandt St. } \\
\text { John's wort }\end{array}$ & A1235 & Crude & $>25$ & $\begin{array}{l}\text { (Madunić et al. } \\
\text { 2016) }\end{array}$ & II & Austria & N/A & VI.E.116. \\
\hline Hypericaceae & $\begin{array}{l}\text { Hypericum uralum } \\
\text { Buch.-Ham. ex } \\
\text { D.Don }\end{array}$ & $\begin{array}{l}\text { Nepal St Johns } \\
\text { Wort }\end{array}$ & MCF7/DOX & Subfraction & 1.44 & $\begin{array}{l}\text { (X. Li et al. } \\
\text { 2017) }\end{array}$ & $\begin{array}{c}\text { I.B } \\
\text { Contains Uralione Q }\end{array}$ & Austria & N/A & VI.E.117. \\
\hline Iridaceae & Iris halophila Pall. & $\begin{array}{l}\text { Long leafed } \\
\quad \text { flag }\end{array}$ & $\begin{array}{l}\text { KB } \\
\text { HMEC }\end{array}$ & Subfraction & $\begin{array}{l}5.22 \\
6.79\end{array}$ & $\begin{array}{l}\text { (Y.-Q. Wang } \\
\text { et al. 2003) }\end{array}$ & II. Contains halophilol A & Asia, Europe & N/A & I.J.I.22. \\
\hline Iridaceae & Iris pseudacorus L. & $\begin{array}{l}\text { Yellow flag, } \\
\text { yellow iris }\end{array}$ & N/A & Subfraction & N/A & (Kaššák, 2012) & $\begin{array}{c}\text { IV } \\
\text { Contains irisquinone A }\end{array}$ & America & $\begin{array}{c}\text { LC } \\
\text { (Kavak, } \\
\text { 2014) }\end{array}$ & I.G.100 \\
\hline Juglandaceae & $\begin{array}{c}\text { Pterocarya } \\
\text { stenoptera DC. }\end{array}$ & $\begin{array}{l}\text { Chinese } \\
\text { wingnut }\end{array}$ & MCF7 & Subfraction & N/A & $\begin{array}{l}\text { (Kuo et al. } \\
\text { 2007) }\end{array}$ & $\begin{array}{c}\text { IV } \\
\text { Contains Pterocarnin A }\end{array}$ & $\begin{array}{c}\text { China } \\
\text { Switzer-land }\end{array}$ & $\begin{array}{l}\text { LC (Song, } \\
\text { et al., } \\
2019 \text { ) }\end{array}$ & $\begin{array}{l}\text { IV.E.20.IV.E.4 } \\
9 .\end{array}$ \\
\hline Lamiaceae & $\begin{array}{c}\text { Clerodendrum } \\
\text { trichotomum Thunb. }\end{array}$ & $\begin{array}{l}\text { Harlequin } \\
\text { glorybower }\end{array}$ & $\mathrm{HeLa}$ & Subfraction & 28.92 & $\begin{array}{l}\text { (Xu et al. } \\
\text { 2013) }\end{array}$ & $\begin{array}{c}\mathrm{II} \\
\text { Contains (20R,22E,24R)- } \\
\text { Stigmasta-5,22,25-trien- } \\
\text { 3b,7b-diol }\end{array}$ & W. Java & N/A & I.D.81. \\
\hline Lamiaceae & $\begin{array}{l}\text { Rotheca serrata }(\mathrm{L} .) \\
\text { Steane and Mabb. }\end{array}$ & Senggugu & EACC & Crude & $>250$ & $\begin{array}{l}\text { (Raman et al. } \\
\text { 2015) }\end{array}$ & III & $\begin{array}{l}\text { Myanmar, } \\
\text { India }\end{array}$ & N/A & IV.C.7-7a. \\
\hline
\end{tabular}




\begin{tabular}{|c|c|c|c|c|c|c|c|c|c|c|}
\hline Lamiaceae & $\begin{array}{l}\text { Gmelina arborea } \\
\text { Roxb. }\end{array}$ & Jati putih & $\begin{array}{c}\text { MDA-MB-231 } \\
\text { MDA-MB-435 } \\
\text { B16F10 } \\
\text { CaCo-2 } \\
\text { C6 } \\
\text { SNB-75 }\end{array}$ & Crude & $\begin{array}{l}0.246 \\
0.379 \\
0.246 \\
0.250 \\
0.304 \\
0.404\end{array}$ & $\begin{array}{l}\text { (N'gaman et } \\
\text { al. 2014) }\end{array}$ & I.A & Jambi & $\begin{array}{l}\text { LC }(\text { de } \\
\text { Kok, } \\
2019)\end{array}$ & $\begin{array}{l}\text { XVIII.B.55- } \\
\text { 55a }\end{array}$ \\
\hline Lamiaceae & Leonurus cardiaca $\mathrm{L}$. & Motherwort & N/A & N/A & N/A & $\begin{array}{l}\text { (Sadowska et } \\
\text { al. 2017) }\end{array}$ & $\begin{array}{c}\text { IV } \\
\text { Immunomodulator and } \\
\text { antioxidant }\end{array}$ & Europe & N/A & IV.B.2-2a. \\
\hline Lamiaceae & $\begin{array}{c}\text { Mentha canadensis } \\
\text { L. }\end{array}$ & $\begin{array}{l}\text { American wild } \\
\text { mint }\end{array}$ & N/A & N/A & N/A & $\begin{array}{l}\text { (Kapp 2015; } \\
\text { Hossan et al. } \\
\text { 2014) }\end{array}$ & $\begin{array}{l}\text { IV. Contains Rosmarinic } \\
\text { acid, cathecin }\end{array}$ & Europe & N/A & I.G.180. \\
\hline Lamiaceae & Mentha $\mathrm{x}$ piperita $\mathrm{L}$. & Peppermint & $\begin{array}{l}\text { SPC-A1 } \\
\text { K-562 } \\
\text { SGC-7901 }\end{array}$ & Essential oil & $\begin{array}{l}10.89 \\
16.16 \\
38.76\end{array}$ & $\begin{array}{l}\text { (Sun et al. } \\
\text { 2014) }\end{array}$ & II & Europe & N/A & I.G.60. \\
\hline Lamiaceae & $\begin{array}{l}\text { Salvia farinacea } \\
\text { Benth. }\end{array}$ & Salvia ungu & $\begin{array}{c}\text { MCF7 } \\
\text { NHI-H460 } \\
\text { HeLa } \\
\text { HepG2 }\end{array}$ & Crude & $\begin{array}{c}59.8 \pm 0.1 \\
279.5 \pm 10.1 \\
77.8 \pm 3.5 \\
87.4 \pm 5.4\end{array}$ & $\begin{array}{l}\text { (Afonso et al. } \\
\text { 2019) }\end{array}$ & II & $\begin{array}{l}\text { Mexico, } \\
\text { Texas }\end{array}$ & N/A & I.J.II.1. \\
\hline Lamiaceae & $\begin{array}{l}\text { Salvia splendens } \\
\text { Sellow ex Schult. }\end{array}$ & Salvia merah & N/A & N/A & N/A & $\begin{array}{l}\text { (Chopra et al. } \\
\text { 2016) }\end{array}$ & $\begin{array}{c}\text { IV } \\
\text { Contains quercetin }\end{array}$ & Brazil & N/A & $\begin{array}{l}\text { I.A.66; I.G.57; } \\
\text { IV.A.87. }\end{array}$ \\
\hline Lauraceae & $\begin{array}{l}\text { Cinnamomum bur- } \\
\text { manni (Nees and } \\
\text { T.Nees) Blume }\end{array}$ & $\begin{array}{l}\text { Holim, cassia } \\
\text { paandg }\end{array}$ & $\mathrm{T}-47 \mathrm{D}$ & Crude & 75 & $\begin{array}{l}\text { (Anjarsari et } \\
\text { al. 2013) }\end{array}$ & II & Java & N/A & $\begin{array}{c}\text { VIII.B.69-69a; } \\
\text { VII.C. 7-7c; } \\
\text { X.A.4-4a; } \\
\text { XI.A.25; } \\
\text { XII.B.12-12a, } \\
\text { 53; XIII.A.9d- } \\
\text { 9f; XIV.A. 4- } \\
\text { 4a. }\end{array}$ \\
\hline Lauraceae & $\begin{array}{c}\text { Cinnamomum } \\
\text { camphora (L.) J.Pres] }\end{array}$ & Camphor & MCF7 & Crude & $71.2 \pm 26.8$ & $\begin{array}{c}\text { (Satyal et al. } \\
\text { 2013; Bando- } \\
\text { padhyaya et al. } \\
\text { 2015) }\end{array}$ & II & China, Japan & N/A & $\begin{array}{l}\text { I.L.11-11a; } \\
\text { II.A.8-8a; } \\
\text { II.B.4-4a; } \\
\text { II.C.1-1a, 24- } \\
\text { 24b-24c; } \\
\text { VIII.B.43-43a; } \\
\text { XI.A. 27-27a; } \\
\text { XIII.B.1-1a (4; } \\
\text { XIV.A. 21- } \\
\text { 21a, 86-86a. }\end{array}$ \\
\hline
\end{tabular}




\begin{tabular}{|c|c|c|c|c|c|c|c|c|c|c|}
\hline Lauraceae & $\begin{array}{l}\text { Cinnamomum cassia } \\
\text { (L). J.Presl }\end{array}$ & Casia cina & $\begin{array}{l}\text { HL-60 } \\
\text { A549 }\end{array}$ & Subfraction & $\begin{array}{l}3.18 \\
4.38\end{array}$ & $\begin{array}{l}\text { (Ngoc et al. } \\
\text { 2014) }\end{array}$ & $\begin{array}{c}\text { I.B } \\
\text { Contains Coumacassia } \\
{[6,7-\text { dimethoxy-8-O-(2',3'- }} \\
\text { epoxy-3',7'-dimethyloct- } \\
\text { 6'-en-5'-one-1-yl)coumarin] }\end{array}$ & $\begin{array}{l}\text { S. Sumatra } \\
\text { W. Sumatra } \\
\text { China, } \\
\text { Myanmar } \\
\text { Jambi } \\
\text { W. Java }\end{array}$ & N/A & $\begin{array}{c}\text { II.A.62-62a; } \\
\text { II.A.59-59c; } \\
\text { VII.C.80; } \\
\text { IX.B.108, 109; } \\
\text { VII.C. 149; } \\
\text { VIII.B. 81- } \\
\text { 81a; } \\
\text { XIX.A.12-12a }\end{array}$ \\
\hline Lauraceae & $\begin{array}{l}\text { Cinnamomum iners } \\
\text { Reinw. ex Blume }\end{array}$ & $\begin{array}{l}\text { Huru geding, } \\
\text { kayu tuha }\end{array}$ & НCТ-116 & Crude & 31 & $\begin{array}{l}\text { (Ghalib et al. } \\
\text { 2011) }\end{array}$ & II & $\begin{array}{l}\text { W. Sumatra } \\
\text { W. Java }\end{array}$ & $\begin{array}{l}\text { LC (de } \\
\text { Kok, } \\
2019)\end{array}$ & $\begin{array}{l}\text { VIII.B.260; } \\
\text { XIV.A.66-66a; } \\
\text { II.A.64; } \\
\text { XIV.A.93. }\end{array}$ \\
\hline Lauraceae & $\begin{array}{l}\text { Cinnamomum } \\
\text { subavenium Miq. }\end{array}$ & Sabal-sabal & $\begin{array}{l}\text { A549 } \\
\text { DU-145 } \\
\text { LNCaP }\end{array}$ & Subfraction & $\begin{array}{l}2.24 \pm 0.03 \\
2.42 \pm 0.01 \\
7.01 \pm 0.03\end{array}$ & $\begin{array}{l}\text { (R.-J. Lin et al. } \\
\text { 2008) }\end{array}$ & I.B & Jambi & $\begin{array}{l}\text { LC }(\text { de } \\
\text { Kok, } \\
2020)\end{array}$ & XVIII.B.39. \\
\hline Lauraceae & $\begin{array}{c}\text { Cinnamomum verum } \\
\text { J.Presl }\end{array}$ & True cinnamon & Hep3B & Crude & 3.62 & $\begin{array}{l}\text { (Perng et al. } \\
\text { 2016) }\end{array}$ & $\begin{array}{l}\text { I.B. Contains 2- } \\
\text { methoxycinnamaldehyde }\end{array}$ & $\begin{array}{c}\text { Jambi } \\
\text { Bengkulu }\end{array}$ & N/A & $\begin{array}{l}\text { VIII.A.34-34a; } \\
\text { VIII.B.337. }\end{array}$ \\
\hline Lauraceae & $\begin{array}{c}\text { Cinnamomun } \\
\text { zeylanicum Blume }\end{array}$ & Kayu manis & MCF7 & Crude & 58 & $\begin{array}{l}\text { (Abd Wahab } \\
\text { and Adzmi } \\
\text { 2017; Kubatka } \\
\text { et al. 2020) }\end{array}$ & II. In vivo study & N/A & N/A & VIII.B.337. \\
\hline Lauraceae & $\begin{array}{c}\text { Cryptocarya } \\
\text { chinensis (Hance) } \\
\text { Hemsl. }\end{array}$ & $\begin{array}{l}\text { Cryptocarya } \\
\text { cina }\end{array}$ & $\begin{array}{l}\text { L1210 } \\
\text { P388 } \\
\text { A549 } \\
\text { HCT-8 }\end{array}$ & Subfraction & $\begin{array}{c}0.1 \\
0.1 \\
0.002 \\
0.001\end{array}$ & $\begin{array}{l}\text { (T.-S. Wu et } \\
\text { al. 2012) }\end{array}$ & $\begin{array}{c}\text { I.A } \\
\text { Contains (-)-antofine and } \\
\text { dehydroantofine }\end{array}$ & $\begin{array}{l}\text { Java, } \\
\text { Sumatra }\end{array}$ & N/A & VI.D.50. \\
\hline Lauracea & $\begin{array}{c}\text { Cryptocarya costata } \\
\text { Blume }\end{array}$ & N/A & P388 & Subfraction & 1.71 & $\begin{array}{l}\text { (Usman et al. } \\
\text { 2006) }\end{array}$ & $\begin{array}{l}\text { I.B. Contains 2',4'- } \\
\text { dihydroxy-5',6'- } \\
\text { dimethoxychalcone }\end{array}$ & C. Java & $\begin{array}{l}\text { LC }(\mathrm{de} \\
\text { Kok, } \\
2020)\end{array}$ & VIII.B.263. \\
\hline Lauracea & $\begin{array}{c}\text { Cryptocarya } \\
\text { crassinervia Miq. }\end{array}$ & Meandg batu & $\begin{array}{l}\text { A549, MCF7, } \\
\text { HT-29 }\end{array}$ & Crude & $>10$ & $\begin{array}{l}\text { (Awang et al. } \\
\text { 2008; Cortez } \\
\text { et al. 2017) }\end{array}$ & II. Contains (-) Grandisin & W. Sumatra & N/A & VII.C.307. \\
\hline Lauracea & $\begin{array}{c}\text { Cryptocarya konishii } \\
\text { Hayata }\end{array}$ & N/A & $\begin{array}{c}\text { P388 } \\
\text { HL-60 } \\
\text { HCT-116 } \\
\text { A549 }\end{array}$ & Subfraction & $\begin{array}{l}0.01 \\
0.55 \\
1.98 \\
4.28\end{array}$ & $\begin{array}{l}\text { (Kurniadewi et } \\
\text { al. 2010) }\end{array}$ & $\begin{array}{c}\text { I.A } \\
\text { Contains } \\
\text { Desmethylinfectocaryone } \\
\text { and Cryptocaryone }\end{array}$ & Formosa & N/A & XV.B.15-15a. \\
\hline Lauracea & $\begin{array}{c}\text { Cryptocarya } \\
\text { laevigata } \text { Blume }\end{array}$ & $\begin{array}{l}\text { Red-fruited } \\
\text { laurel }\end{array}$ & $\begin{array}{c}\text { A549 } \\
\text { MDA-MB-231 } \\
\text { MCF7 } \\
\text { KB } \\
\text { KB-VIN }\end{array}$ & Subfraction & $\begin{array}{l}0.021 \\
0.086 \\
0.134 \\
0.074 \\
0.078\end{array}$ & $\begin{array}{l}\text { (Suzuki et al. } \\
\text { 2018) }\end{array}$ & $\begin{array}{c}\text { I.A } \\
\text { Contains }(-)- \\
\text { neocaryachine }\end{array}$ & $\begin{array}{l}\text { China, } \\
\text { Myanmar } \\
\text { Lampung } \\
\text { W. Java }\end{array}$ & $\begin{array}{l}\text { LC (BGCI } \\
\text { and IUCN, } \\
2018)\end{array}$ & $\begin{array}{l}\text { XIV.A.30-30a; } \\
\text { IX.A.60; } \\
\text { XV.B.27. }\end{array}$ \\
\hline Lauraceae & $\begin{array}{c}\text { Cryptocarya } \\
\text { strictifolia } \text { Kosterm. }\end{array}$ & N/A & N/A & N/A & N/A & $\begin{array}{l}\text { (Juliawaty et } \\
\text { al. 2000; Rasul } \\
\text { et al. 2013) }\end{array}$ & $\begin{array}{c}\text { IV } \\
\text { Contains pinocembrin }\end{array}$ & N. Sulawesi & N/A & VIII.A.32. \\
\hline
\end{tabular}




\begin{tabular}{|c|c|c|c|c|c|c|c|c|c|c|}
\hline Lauraceae & Laurus nobilis $\mathrm{L}$. & Bay leaf & $\begin{array}{l}\text { MCF7 } \\
\text { T-47D }\end{array}$ & Crude & $\begin{array}{c}28 \\
12.3 \pm 4.0\end{array}$ & $\begin{array}{l}\text { (Abu-Dahab et } \\
\text { al. 2014) }\end{array}$ & II & Medit Reg. & $\begin{array}{l}\text { LC (Khela, } \\
\text { and } \\
\text { Wilson, } \\
\text { 2018) }\end{array}$ & $\begin{array}{l}\text { XIII.B.4; } \\
\text { XV.B. } 25 .\end{array}$ \\
\hline Lauraceae & $\begin{array}{c}\text { Lindera polyantha } \\
\text { Boerl. }\end{array}$ & $\begin{array}{l}\text { Spicewood, } \\
\text { spicebush, } \\
\text { benjamin bush }\end{array}$ & N/A & Subfraction & N/A & $\begin{array}{l}\text { (Suastri et al. } \\
\text { 2005, Yoon et } \\
\text { al. 2020) }\end{array}$ & $\begin{array}{c}\text { IV } \\
\text { Contains linderin and metil } \\
\text { linderin }\end{array}$ & W. Java & N/A & $\begin{array}{l}\text { VII.C.46-46a- } \\
\text { 46b, 381; } \\
\text { VIII.B. 54- } \\
\text { 54a. }\end{array}$ \\
\hline Lauraceae & $\begin{array}{c}\text { Litsea cubeba (Lour.) } \\
\text { Pers. }\end{array}$ & $\begin{array}{l}\text { Kilemo, } \\
\text { krangean }\end{array}$ & $\begin{array}{c}\text { J5 } \\
\text { A549 }\end{array}$ & Crude & $\begin{array}{c}50 \\
100\end{array}$ & $\begin{array}{l}\text { (Ho et al. } \\
2010)\end{array}$ & II & $\begin{array}{l}\text { W. Java } \\
\text { S. Sumatra } \\
\text { W. Sumatra }\end{array}$ & N/A & $\begin{array}{l}\text { VII.C.136; } \\
\text { VIII.B.298, } \\
302 ; \\
\text { VIII.B.256; } \\
\text { XIX.B.18. }\end{array}$ \\
\hline Lauraceae & $\begin{array}{l}\text { Litsea elliptica } \\
\text { Blume }\end{array}$ & N/A & A549 & Crude & N/A & $\begin{array}{l}\text { Goh et al. } \\
2018\end{array}$ & IV & $\begin{array}{l}\text { W. Java } \\
\text { Lampung }\end{array}$ & $\begin{array}{l}\text { LC }(\text { de } \\
\text { Kok, } \\
2020)\end{array}$ & $\begin{array}{l}\text { VIII.B.121; } \\
\text { II.A.86; }\end{array}$ \\
\hline Lauraceae & Litsea garciae Vidal & N/A & $\begin{array}{l}\text { MCF7 } \\
\text { HT-29 }\end{array}$ & Crude & $\begin{array}{l}66 \\
73\end{array}$ & $\begin{array}{l}\text { (Kutoi et al. } \\
\text { 2012) }\end{array}$ & II & $\begin{array}{l}\text { C. Sulawesi } \\
\text { S. Sumatra } \\
\text { Aceh, W. } \\
\text { Sumatra }\end{array}$ & $\begin{array}{l}\text { LC (de } \\
\text { Kok, } \\
2020)\end{array}$ & $\begin{array}{l}\text { VII.B.86; } \\
\text { VIII.B.299; } \\
\text { VII.B.228; } \\
\text { IX.B.158- } \\
\text { 158a; VIII. } \\
\text { C.121-121a. }\end{array}$ \\
\hline Lauraceae & $\begin{array}{l}\text { Litsea mappacea } \\
\text { Boerl. }\end{array}$ & Huru koneng & $\mathrm{MCF}$ & Crude & 200 & $\begin{array}{l}\text { (Subarnas et } \\
\text { al. 2012) }\end{array}$ & III & $\begin{array}{l}\text { W. Java } \\
\text { W. Sumatra }\end{array}$ & N/A & $\begin{array}{l}\text { V.B.33; } \\
\text { VII.C.51b-51c; } \\
\text { VIII.B. 239a; } \\
\text { VIII.B.285. }\end{array}$ \\
\hline Lauraceae & $\begin{array}{l}\text { Litsea monopetala } \\
\text { (Roxb.) Pers. }\end{array}$ & N/A & MDA-MB-231 & Crude & N/A & $\begin{array}{c}\text { (Shen et al. } \\
\text { 2014) }\end{array}$ & $\begin{array}{c}\text { IV. Chemo-preventive } \\
\text { agent }\end{array}$ & Bengkulu & N/A & II.A.87. \\
\hline Lauraceae & $\begin{array}{c}\text { Persea americana } \\
\text { Mill. }\end{array}$ & Alpukat & MCF7 & Subfraction & 20.48 & $\begin{array}{l}\text { (Falodun et al. } \\
\text { 2013) }\end{array}$ & $\begin{array}{l}\text { II. Contains 4-hydroxy-5- } \\
\text { methylene-3-undecyclidene- } \\
\text { dihydrofuran-2 (3H)- } \\
\text { one }\end{array}$ & Mexico & $\begin{array}{c}\text { LC } \\
\text { (Wegier, et } \\
\text { al., 2017) }\end{array}$ & VIII.B.223b. \\
\hline Leguminosae & $\begin{array}{l}\text { Acacia caffra } \\
\text { (Thunb.) Willd. }\end{array}$ & Hook thorn & $\begin{array}{l}\text { HeLa } \\
\text { A431 } \\
\text { A375 }\end{array}$ & Crude & $\begin{array}{c}185.00 \pm 0.4 \\
132.00 \pm 0.7 \\
>200\end{array}$ & $\begin{array}{c}\text { (Twilley et al. } \\
\text { 2017) }\end{array}$ & III & S. Africa & N/A & $\begin{array}{l}\text { VIII.A.75-75a- } \\
\text { 75b. }\end{array}$ \\
\hline Leguminosae & $\begin{array}{l}\text { Acacia farnesiana } \\
\text { (L.) Willd. }\end{array}$ & Kembang jepun & $\begin{array}{c}\text { HepG2 } \\
\text { MDA-MB-231 } \\
\text { A549 } \\
\text { Ca9-22 }\end{array}$ & Subfraction & $\begin{array}{l}1.87 \pm 0.04 \\
5.38 \pm 0.05 \\
1.70 \pm 0.04 \\
1.80 \pm 0.04\end{array}$ & $\begin{array}{l}\text { (A.-S. Lin et } \\
\text { al. 2009) }\end{array}$ & $\begin{array}{c}\text { I.A } \\
\text { Contains betulinic acid and } \\
\text { diosmetin }\end{array}$ & $\begin{array}{l}\text { Trop. } \\
\text { America }\end{array}$ & $\begin{array}{l}\text { LC (BGCI } \\
\text { and IUCN, } \\
2020)\end{array}$ & VIII.B.2. \\
\hline
\end{tabular}




\begin{tabular}{|c|c|c|c|c|c|c|c|c|c|c|}
\hline Leguminosae & $\begin{array}{c}\text { Acacia tenuifolia }(\mathrm{L} .) \\
\text { Willd. }\end{array}$ & Ara a gato & $\begin{array}{l}\text { M109 } \\
\text { A2780 }\end{array}$ & Subfraction & $\begin{array}{c}1 \\
13.0\end{array}$ & $\begin{array}{l}\text { (Seo et al. } \\
2002 \text { ) }\end{array}$ & $\begin{array}{c}\text { I.B } \\
\text { Contains Albiziatrioside A } \\
\text { 3-O-[â-D-xylono-pyranosyl- } \\
\text { (1f2)-r-Larabinopyranosyl- } \\
\text { (1f6)-2-acetamido-2-deoxy- } \\
\text { â-D-gluco- } \\
\text { pyranosyl]oleanolic acid, 3- } \\
\text { O-[r-L-Arabinopyranosyl- } \\
\text { (1f2)-r-L-arabino-pyranosyl- } \\
\text { (1f6)-2-acetamido-2-deoxy- } \\
\text { â-D-glucopy- } \\
\text { ranosyl]oleanolic acid, } \\
\text { Acacioside B and Acacioside } \\
\text { C }\end{array}$ & Venezuela & N/A & VII.A.62-62a. \\
\hline Leguminosae & $\begin{array}{l}\text { Bauhinia integrifolia } \\
\text { Roxb. }\end{array}$ & $\begin{array}{l}\text { Flame vine } \\
\text { bauhinia }\end{array}$ & N/A & Crude & N/A & $\begin{array}{l}\text { (Allado-Ombat } \\
\text { and Teves } \\
\text { 2015) }\end{array}$ & $\begin{array}{c}\text { IV } \\
\text { Antiangiogenic }\end{array}$ & $\begin{array}{c}\text { Malaya \& } \\
\text { Sumatra }\end{array}$ & N/A & III.C.54. \\
\hline Leguminosae & $\begin{array}{c}\text { Bauhinia } \\
\text { strychnifolia Craib }\end{array}$ & Yhanang andg & $\begin{array}{l}\text { HT-29 } \\
\text { HeLa } \\
\text { MCF7 } \\
\text { KB }\end{array}$ & Subfraction & $\begin{array}{c}0.00217 \\
0.06927 \\
0.05857 \\
0.000547\end{array}$ & $\begin{array}{l}\text { (Yuenyongsaw } \\
\text { ad et al. 2013) }\end{array}$ & $\begin{array}{c}\text { I.A } \\
\text { Contains 3,5,7,3',5'- } \\
\text { Pentahydroxy-flavanonol- } \\
\text { 3-O- } \alpha \text {-Lrhamnopyranoside }\end{array}$ & C. Sulawesi & N/A & VII.B.220. \\
\hline Leguminosae & $\begin{array}{c}\text { Bauhinia variegata } \\
\text { L. }\end{array}$ & $\begin{array}{l}\text { Camel's foot } \\
\text { tree }\end{array}$ & $\begin{array}{c}\text { HEp2 } \\
\text { HBL-100 }\end{array}$ & Crude & $\begin{array}{c}250 \\
>300\end{array}$ & $\begin{array}{l}\text { (Rajkapoor et } \\
\text { al. 2006) }\end{array}$ & III & $\begin{array}{l}\text { Myanmar, E. } \\
\text { India }\end{array}$ & $\begin{array}{l}\text { LC (Chad- } \\
\text { burn, } \\
2012)\end{array}$ & II.D.7; IV.D.7. \\
\hline Leguminosae & $\begin{array}{l}\text { Caesalpinia gilliesii } \\
\text { (Hook.) D.Dietr. }\end{array}$ & $\begin{array}{l}\text { Kembang } \\
\text { merak }\end{array}$ & MCF7 & Crude & 36.5 & $\begin{array}{c}\text { (Emam et al. } \\
\text { 2017) }\end{array}$ & II & Australia & N/A & I.K.59-59a. \\
\hline Leguminosae & $\begin{array}{c}\text { Caesalpinia sappan } \\
\text { L. }\end{array}$ & Secang & $4 \mathrm{~T} 1$ & Crude & 13.1 & $\begin{array}{l}\text { (Haryanti et al. } \\
\text { 2018) }\end{array}$ & I.D & Aceh & $\begin{array}{l}\text { LC (World } \\
\text { Conser- } \\
\text { vation } \\
\text { Monitor- } \\
\text { ing Centre, } \\
2018 \text { ) }\end{array}$ & IX.B.70. \\
\hline Leguminosae & $\begin{array}{l}\text { Caesalpinia spinosa } \\
\text { (Molina) Kuntze }\end{array}$ & Divi-divi, tara & K-562 & Subfraction & $44.50 \pm 4.05$ & $\begin{array}{l}\text { (Castañeda et } \\
\text { al. 2012) }\end{array}$ & II & Pantro-pical & N/A & $\begin{array}{l}\text { IV.E.30b; } \\
\text { XIV.A.47; } \\
\text { XIV.B.4-4a. }\end{array}$ \\
\hline Leguminosae & $\begin{array}{l}\text { Dalbergia parviflora } \\
\text { Roxb. }\end{array}$ & Akar laka & $\begin{array}{c}\text { KB } \\
\text { MCF7 } \\
\text { NCI-H187 }\end{array}$ & Subfraction & $\begin{array}{l}4.18 \\
5.37 \\
3.47\end{array}$ & $\begin{array}{l}\text { (Songsiang et } \\
\text { al. 2011) }\end{array}$ & $\begin{array}{c}\text { I.A } \\
\text { Contains secundiflorol } \mathrm{H}\end{array}$ & W. Java & $\begin{array}{l}\text { LC (Chad- } \\
\text { burn, } \\
2012)\end{array}$ & XIX.A.16. \\
\hline Leguminosae & $\begin{array}{l}\text { Derris elliptica } \\
\text { (Wall.) Benth. }\end{array}$ & Tuba & $\begin{array}{l}\text { HCT-116 } \\
\text { MCF7 }\end{array}$ & Crude & $\begin{array}{l}37 \pm 1.5 \\
34 \pm 0.8\end{array}$ & $\begin{array}{c}\text { (Fayad et al. } \\
\text { 2015) }\end{array}$ & II & Lampung & N/A & $\begin{array}{l}\text { IX.B.103- } \\
103 a .\end{array}$ \\
\hline
\end{tabular}




\begin{tabular}{|c|c|c|c|c|c|c|c|c|c|c|}
\hline Leguminosae & $\begin{array}{l}\text { Enterolobium } \\
\text { contortisiliquum } \\
\text { (Vell.) Morong }\end{array}$ & Earpod tree & $\begin{array}{l}\text { HepG2 } \\
\text { MCF7 }\end{array}$ & Crude & $\begin{array}{l}15.7 \\
12.3\end{array}$ & $\begin{array}{l}\text { (Matloub et al. } \\
\text { 2018; Abdel- } \\
\text { Mageed et al. } \\
\text { 2019) }\end{array}$ & $\begin{array}{c}\text { I.C } \\
\text { Contains contortisilioside E }\end{array}$ & $\begin{array}{l}\text { American } \\
\text { Trop. }\end{array}$ & $\begin{array}{c}\text { LC (BGCI } \\
\text { and IUCN, } \\
2019)\end{array}$ & $\begin{array}{l}\text { I.J.19; I.K. 72- } \\
\text { 72a-72b; } \\
\text { V.C.39-39a, } \\
\text { 62; VIII.B. } \\
\text { 303-303a. }\end{array}$ \\
\hline Leguminosae & $\begin{array}{c}\text { Erythrina abyssinica } \\
\text { DC. }\end{array}$ & $\begin{array}{l}\text { Red-hot poker, } \\
\text { coral tree }\end{array}$ & $\begin{array}{c}\text { MCF7 } \\
\text { MCF/TAMR } \\
\text { MCF/ADR } \\
\text { MDA-MB-231 }\end{array}$ & Subfraction & $\begin{array}{l}4.61 \\
2.42 \\
2.19 \\
3.01\end{array}$ & $\begin{array}{l}\text { (P. H. Nguyen } \\
\text { et al. 2009) }\end{array}$ & $\begin{array}{c}\text { I.A } \\
\text { Contains erybreadin B }\end{array}$ & E. Africa & $\begin{array}{l}\text { LC (BGCI } \\
\text { and IUCN, } \\
2019)\end{array}$ & V.C.52-52a. \\
\hline Leguminosae & $\begin{array}{c}\text { Erythrina crista-galli } \\
\text { L. }\end{array}$ & Dadap merah & MCF7 & Crude & $23.3 \pm 1.9$ & $\begin{array}{l}\text { (Ashmawy et } \\
\text { al. 2016) }\end{array}$ & II & Brazil & $\begin{array}{l}\text { LC (BGCI } \\
\text { and IUCN, } \\
\text { 2019) }\end{array}$ & $\begin{array}{l}\text { V.C. } 50-50 \mathrm{a}- \\
50 \mathrm{~b} .\end{array}$ \\
\hline Leguminosae & Erythrina fusca Lour. & Cangkring & HeLa & Crude & 76 & $\begin{array}{l}\text { (Meiyanto et } \\
\text { al. 2007) }\end{array}$ & II & C. Java & N/A & V.C.58. \\
\hline Leguminosae & $\begin{array}{c}\text { Flemingia } \\
\text { macrophylla (Willd.) } \\
\text { Merr. }\end{array}$ & Hahapaan & MCF7 & Subfraction & N/A & $\begin{array}{l}\text { (W.-C. Lai et } \\
\text { al. 2013) }\end{array}$ & $\begin{array}{l}\text { IV } \\
\text { Contains flemiphilippinin } \\
\text { D and flemichin-D }\end{array}$ & Africa, Asia & N/A & VI.C.65. \\
\hline Leguminosae & $\begin{array}{l}\text { Gleditsia sinensis } \\
\text { Lam. }\end{array}$ & $\begin{array}{l}\text { Chinese honey } \\
\text { locust }\end{array}$ & MCF7 & Subfraction & 19.54 & $\begin{array}{l}\text { (Yu et al. } \\
\text { 2019) }\end{array}$ & II. Contains gleditsioside F & China & $\begin{array}{l}\text { LC (BGCI } \\
\text { and IUCN, } \\
2019)\end{array}$ & III.C.2. \\
\hline Leguminosae & $\begin{array}{l}\text { Pterocarpus indicus } \\
\text { Willd. }\end{array}$ & $\begin{array}{l}\text { Angsana, sono } \\
\text { kembang, } \\
\text { Papua New } \\
\text { Guinea } \\
\text { rosewood }\end{array}$ & N/A & N/A & N/A & $\begin{array}{l}\text { (Takeuchi et } \\
\text { al. 1986; J. } \\
\text { Yang et al. } \\
\text { 2020) }\end{array}$ & $\begin{array}{l}\text { IV } \\
\text { Contains cinnamaldehyde } \\
\text { (E) }\end{array}$ & Maluku & $\begin{array}{c}\text { EN } \\
\text { (Barstow, } \\
\text { 2018) }\end{array}$ & XIII.B.8-8a. \\
\hline Leguminosae & $\begin{array}{c}\text { Sophora tetraptera } \\
\text { J.F.Mill. }\end{array}$ & Kowhai & N/A & N/A & N/A & $\begin{array}{l}\text { (Baskar et al. } \\
\text { 2010; } \\
\text { McDougal et } \\
\text { al. 2018) }\end{array}$ & $\begin{array}{c}\text { IV } \\
\text { Contains luteolin-7-O- } \beta \text { - } \\
\text { glucoside and apigenin-7- } \\
\text { O- } \beta \text {-glucoside }\end{array}$ & $\begin{array}{l}\text { New } \\
\text { Zealand }\end{array}$ & N/A & III.C.68. \\
\hline Leguminosae & $\begin{array}{c}\text { Sophora tomentosa } \\
\text { L. }\end{array}$ & Ki ucing & $\begin{array}{l}\text { HSC-2 } \\
\text { HSG }\end{array}$ & Subfraction & $\begin{array}{l}<8 \\
8\end{array}$ & $\begin{array}{l}\text { (Shiratak et al. } \\
\text { 2001) }\end{array}$ & $\begin{array}{c}\text { II } \\
\text { Contains } \\
\text { sophoraflavanone G }\end{array}$ & C. Sulawesi & N/A & $\begin{array}{l}\text { VIII.B.111- } \\
\text { 111a; } \\
\text { VIII.C. } 138 .\end{array}$ \\
\hline Malvaceae & $\begin{array}{c}\text { Cola acuminata } \\
\text { (P.Beauv.) Schott anc } \\
\text { Endl. }\end{array}$ & Bissy, true kola & $\begin{array}{l}\text { LNCaP } \\
\text { DU-145 }\end{array}$ & Crude & $\begin{array}{l}15 \\
3.6\end{array}$ & $\begin{array}{l}\text { (Solipuram et } \\
\text { al. 2009) }\end{array}$ & I.D & Borneo & $\begin{array}{l}\text { LC (Cheek } \\
\text { and } \\
\text { Lawrence } \\
\text { 2019) }\end{array}$ & VII.C.73. \\
\hline Malvaceae & $\begin{array}{l}\text { Cola nitida (Vent.) } \\
\text { Schott and Endl. }\end{array}$ & Kola nut & HepG2 & Crude & 6.5 & $\begin{array}{c}\text { (Endrini and } \\
\text { Marsiati 2009) }\end{array}$ & I.D & W. Africa & $\begin{array}{c}\text { LC (Cheek } \\
\text { and } \\
\text { Lawrence20 } \\
19)\end{array}$ & $\begin{array}{l}\text { VI.D.99-99a- } \\
\text { 99b. }\end{array}$ \\
\hline Malvaceae & $\begin{array}{l}\text { Hibiscus rosa- } \\
\text { sinensis L. }\end{array}$ & $\begin{array}{l}\text { Kembang } \\
\text { sepatu }\end{array}$ & K-562 & Crude & $30.90 \pm 1.10$ & $\begin{array}{l}\text { (Arullapan et } \\
\text { al. 2013) }\end{array}$ & II & $\begin{array}{l}\text { Japan: Saka- } \\
\text { rotsuji }\end{array}$ & N/A & XV.A.41-41a. \\
\hline
\end{tabular}




\begin{tabular}{|c|c|c|c|c|c|c|c|c|c|c|}
\hline Malvaceae & Hibiscus syriacus L. & $\begin{array}{c}\text { Kembang } \\
\text { sepatu mawar }\end{array}$ & A549 & Subfraction & 2.59 & $\begin{array}{l}\text { (Shi et al. } \\
\text { 2014) }\end{array}$ & $\begin{array}{c}\text { I.B } \\
\text { Contains betulin-3-caffeate }\end{array}$ & $\begin{array}{l}\text { Syrian Arab } \\
\text { Republic }\end{array}$ & N/A & $\begin{array}{l}\text { VI.C. } 13 ; \\
\text { XI.A. } 28 .\end{array}$ \\
\hline Melastomataceae & $\begin{array}{c}\text { Melastoma } \\
\text { malabathricum } \mathrm{L} .\end{array}$ & $\begin{array}{l}\text { Rhododen-dron } \\
\text { singapura }\end{array}$ & MCF7 & Crude & 7.14 & $\begin{array}{l}\text { (Roslen et al. } \\
\text { 2014) }\end{array}$ & I.C & $\begin{array}{l}\text { India, Malay } \\
\text { Pen. }\end{array}$ & N/A & $\begin{array}{l}\text { IV.C. } 72 ; \\
\text { XIV.A.39, } 62 .\end{array}$ \\
\hline Meliaceae & $\begin{array}{l}\text { Aglaia angustifolia } \\
\text { (Miq.) Miq. }\end{array}$ & Pasak bumi & MCF7 & Subfraction & 29.87 & $\begin{array}{l}\text { (Hutagaol et } \\
\text { al. 2020) }\end{array}$ & $\begin{array}{l}\text { II. Contains (22E,24S)-24- } \\
\text { propylcholest-5en-3 } \\
\text {-acetate }\end{array}$ & Aceh & $\begin{array}{c}\text { VU } \\
\text { (Pannel, } \\
\text { 1998) }\end{array}$ & IX.A.208. \\
\hline Meliaceae & $\begin{array}{l}\text { Aglaia argentea } \\
\text { Blume }\end{array}$ & Bayur & $\mathrm{KB}$ & Subfraction & 0.006 & $\begin{array}{l}\text { (Dumontet et } \\
\text { al. 1996) }\end{array}$ & $\begin{array}{c}\text { I.B. Contains } \\
\text { Didesmethylrocaglamid }\end{array}$ & W. Sumatra & $\begin{array}{c}\text { LC } \\
\text { (Pannel, } \\
\text { 1998) }\end{array}$ & $\begin{array}{l}\text { III.F.76; } \\
\text { IX.A.154. }\end{array}$ \\
\hline Meliaceae & $\begin{array}{l}\text { Aglaia edulis (Roxb.) } \\
\text { Wall. }\end{array}$ & Mamuara disik & $\begin{array}{c}\text { LU-1 } \\
\text { LNCaP } \\
\text { MCF7 } \\
\text { HUVEC }\end{array}$ & Subfraction & $\begin{array}{c}0.001 \\
0.01 \\
0.02 \\
0.1\end{array}$ & $\begin{array}{l}\text { (Kim et al. } \\
\text { 2006) }\end{array}$ & $\begin{array}{c}\text { I.A } \\
\text { Contains aglaroxin A, } \\
\text { aglaroxin A 1-O-acetate, } \\
\text { and 3'-methoxyaglaroxin A } \\
\text { 1-Oacetate }\end{array}$ & $\begin{array}{c}\text { Jambi } \\
\text { W. Java }\end{array}$ & $\begin{array}{c}\text { NT } \\
\text { (Pannel, } \\
\text { 1998) }\end{array}$ & $\begin{array}{c}\text { IX.C.39- } \\
\text { 39a.IX.A.165. }\end{array}$ \\
\hline Meliaceae & $\begin{array}{l}\text { Aglaia elliptica } \\
\text { (C.DC.) Blume }\end{array}$ & $\begin{array}{l}\text { Tanglar, } \\
\text { lengsar }\end{array}$ & $\begin{array}{c}\text { BC1 } \\
\text { HT-1080 } \\
\text { LU-1 } \\
\text { Mel2 } \\
\text { Col2 } \\
\text { KB } \\
\text { A431 } \\
\text { LNCaP } \\
\text { ZR-75 } \\
\text { U373 }\end{array}$ & Subfraction & $\begin{array}{l}0.9 \\
3.0 \\
1.0 \\
1.0 \\
2.0 \\
6.0 \\
3.0 \\
2.0 \\
2.0 \\
0.8\end{array}$ & $\begin{array}{l}\text { (Lee et al. } \\
1998)\end{array}$ & $\begin{array}{c}\text { I.A. Contains 4'- } \\
\text { demethoxy-3',4'- } \\
\text { methylenedioxy- } \\
\text { methyl rocaglate and 5 (1- } \\
\text { O-formyl-4'-demethoxy- } \\
\text { 3',4'-methylenedioxy- } \\
\text { methyl } \\
\text { rocaglate }\end{array}$ & $\begin{array}{c}\text { Jambi } \\
\text { W. Java } \\
\text { C. Sulawesi }\end{array}$ & $\begin{array}{c}\text { LC } \\
\text { (Pannel, } \\
\text { 1998) }\end{array}$ & $\begin{array}{l}\text { VIII.B.8; } \\
\text { III.F.75; } \\
\text { IX.A.191; } \\
\text { IX.A.179. }\end{array}$ \\
\hline Meliaceae & Aglaia eximia Miq. & N/A & $\begin{array}{l}\text { P388 } \\
\text { HT-29 }\end{array}$ & Subfraction & $4.26 \pm 0.09$ & $\begin{array}{l}\text { (Awang et al. } \\
\text { 2012; Harneti } \\
\text { et al. 2014) }\end{array}$ & $\begin{array}{c}\text { II } \\
\text { Contains dammar-20,25- } \\
\text { diene-3b,24-diol and } \\
\text { 24(E)-cycloart-24-ene-26- } \\
\text { ol-3-one }\end{array}$ & $\begin{array}{l}\text { Aceh } \\
\text { W. Java }\end{array}$ & N/A & $\begin{array}{c}\text { IX.A.62-62a- } \\
\text { 62b, 65-65a- } \\
\text { 65b; IX.A.68- } \\
\text { 68a, 76-76a, } \\
89 .\end{array}$ \\
\hline Meliaceae & Aglaia forbesii King & Langsat burung & $\mathrm{KB}$ & Subfraction & 0.006 & $\begin{array}{l}\text { (Dumontet et } \\
\text { al. 1996) }\end{array}$ & I.B & W. Java & $\begin{array}{c}\text { NT } \\
\text { (Pannel, } \\
\text { 1998) }\end{array}$ & IX.A.174. \\
\hline Meliaceae & $\begin{array}{l}\text { Aglaia lawii (Wight) } \\
\text { C.J.Salandha }\end{array}$ & Karakil & N/A & N/A & N/A & $\begin{array}{l}\text { (Mohamad et } \\
\text { al. 1999) }\end{array}$ & $\begin{array}{c}\mathrm{IV} \\
\text { Contains aglinin A, aglinin } \\
\mathrm{B} \text {, and rocaglaol }\end{array}$ & $\begin{array}{l}\text { W. Sumatra } \\
\text { Kaliman-tan }\end{array}$ & $\begin{array}{c}\text { LC } \\
\text { (Pannel, } \\
\text { 1998) }\end{array}$ & $\begin{array}{l}\text { IX.A.151; } \\
\text { IX.B.118. }\end{array}$ \\
\hline Meliaceae & Aglaia odorata Lour. & Pacar cina & $\begin{array}{c}\text { HL-60 } \\
\text { SMMC-7721 } \\
\text { A549 }\end{array}$ & Subfraction & $\begin{array}{l}4.43 \\
5.19 \\
5.44\end{array}$ & $\begin{array}{l}\text { (Cai et al. } \\
\text { 2010) }\end{array}$ & $\begin{array}{l}\text { II. Contains dolabellane } \\
\text { diterpenoids }\end{array}$ & China & $\begin{array}{c}\text { NT } \\
\text { (Pannel, } \\
\text { 1998) }\end{array}$ & $\begin{array}{l}\text { III.F.53-53a- } \\
\text { 53b. }\end{array}$ \\
\hline Meliaceae & $\begin{array}{c}\text { Aglaia odoratissima } \\
\text { Blume }\end{array}$ & Kasai & P388 & Crude & N/A & (Huspa, 2009) & IV & W. Java & $\begin{array}{c}\text { LC } \\
\text { (Pannel, } \\
\text { 1998) }\end{array}$ & IX.A.80. \\
\hline
\end{tabular}




\begin{tabular}{|c|c|c|c|c|c|c|c|c|c|c|}
\hline Meliaceae & $\begin{array}{l}\text { Aglaia silvestris } \\
\text { (M.Roem) Merr. }\end{array}$ & Asam mbawang & $\begin{array}{c}\text { Lu1 } \\
\text { LNCaP } \\
\text { MCF7 }\end{array}$ & Subfraction & $\begin{array}{l}1.2 \\
1.5 \\
1.5\end{array}$ & $\begin{array}{l}\text { (Hwang et al. } \\
\text { 2004) }\end{array}$ & $\begin{array}{c}\text { I.A } \\
\text { Contains silvestrol }\end{array}$ & W. Java & $\begin{array}{c}\text { NT } \\
\text { (Pannel, } \\
\text { 1998) }\end{array}$ & III.F.79. \\
\hline Meliaceae & $\begin{array}{l}\text { Aglaia tomentosa } \\
\text { Teijsm. and Binn. }\end{array}$ & Nirmula & N/A & N/A & N/A & $\begin{array}{l}\text { (Mohamad et } \\
\text { al. 1999; } \\
\text { Thuaud et al. } \\
\text { 2009) }\end{array}$ & $\begin{array}{c}\text { IV } \\
\text { Contains rocaglaol }\end{array}$ & N. Sumatra & $\begin{array}{c}\text { LC } \\
\text { (Pannel, } \\
\text { 1998) }\end{array}$ & IX.A.211. \\
\hline Meliaceae & $\begin{array}{c}\text { Chisocheton } \\
\text { lasiocarpus (Miq.) } \\
\text { Valeton }\end{array}$ & N/A & MCF7 & Subfraction & 15.05 & $\begin{array}{l}\text { (Hidayat et al. } \\
\text { 2018) }\end{array}$ & $\begin{array}{c}\text { II } \\
\text { Contains lasiocarpone }\end{array}$ & $\begin{array}{l}\text { Papua } \\
\text { Afrika } \\
\text { Tropis }\end{array}$ & N/A & $\begin{array}{l}\text { IX.A.173; } \\
\text { IX.A.153- } \\
\text { 153a. }\end{array}$ \\
\hline Meliaceae & $\begin{array}{c}\text { Chisocheton patens } \\
\text { Blume }\end{array}$ & $\begin{array}{l}\text { Lamboi, } \\
\text { latupak }\end{array}$ & MCF7 & Subfraction & 1.82 & $\begin{array}{l}\text { (Supratman et } \\
\text { al. 2019) }\end{array}$ & $\begin{array}{c}\text { I.B } \\
\text { Contains chisopaten A and } \\
\text { chisopaten C }\end{array}$ & C. Java & N/A & $\begin{array}{l}\text { IX.A.134- } \\
134 \mathrm{a} .\end{array}$ \\
\hline Meliaceae & $\begin{array}{l}\text { Sandoricum koetjape } \\
\text { (Burm.f.) Merr. }\end{array}$ & $\begin{array}{l}\text { Kecapi, } \\
\text { mangga hutan }\end{array}$ & $\begin{array}{c}\text { MCF7 } \\
\text { MDA-MB-231 T- } \\
\text { 47D } \\
\text { MCF-10A }\end{array}$ & Crude & $44-48$ & $\begin{array}{l}\text { (Aisha et al. } \\
\text { 2009) }\end{array}$ & II & $\begin{array}{l}\text { W. Java } \\
\text { Lampung }\end{array}$ & $\begin{array}{c}\text { LC } \\
\text { (Barstow, } \\
\text { 2018) }\end{array}$ & $\begin{array}{l}\text { IX.A.212; } \\
\text { IX.B.181; } \\
\text { IX.B.180- } \\
\text { 180a. }\end{array}$ \\
\hline Meliaceae & $\begin{array}{l}\text { Toona ciliata } \\
\text { M.Roem. }\end{array}$ & Cedar merah & MCF7 & Crude & $>200$ & $\begin{array}{l}\text { (Nisa et al, } \\
\text { 2014) }\end{array}$ & III & Papua & $\begin{array}{c}\text { LC } \\
\text { (Barstow, } \\
\text { 2018) }\end{array}$ & VII.B.160. \\
\hline Meliaceae & $\begin{array}{l}\text { Toona sinensis (Juss.', } \\
\text { M.Roem. }\end{array}$ & $\begin{array}{l}\text { Surian, mahoni } \\
\text { cina }\end{array}$ & $\begin{array}{l}\text { MGC-803 } \\
\text { PC-3 } \\
\text { A549 } \\
\text { MCF7 } \\
\text { NIH3T3 }\end{array}$ & Subfraction & $\begin{array}{l}7.09 \\
5.65 \\
2.59 \\
4.15 \\
2.48\end{array}$ & $\begin{array}{l}\text { (S. Yang et al. } \\
\text { 2013) }\end{array}$ & $\begin{array}{c}\text { I.A } \\
\text { Contains daucosterol and } \\
\text { quercetin }\end{array}$ & $\begin{array}{c}\text { India to S. } \\
\text { China \& } \\
\text { Malesia } \\
\text { India } \\
\text { Papua }\end{array}$ & $\begin{array}{c}\text { LC } \\
\text { (Barstow, } \\
\text { 2019) }\end{array}$ & $\begin{array}{l}\text { I.A.48; } \\
\text { VIII.B.224; } \\
\text { VII.C.362- } \\
\text { 362a; } \\
\text { VII.B.127. }\end{array}$ \\
\hline Meliaceae & $\begin{array}{l}\text { Toona sureni } \\
\text { (Blume) Merr. }\end{array}$ & Suren & $\begin{array}{l}\text { Raji } \\
\text { Hela }\end{array}$ & Crude & $\begin{array}{l}31 \\
65\end{array}$ & $\begin{array}{l}\text { (Sari et al. } \\
\text { 2012) }\end{array}$ & II & $\begin{array}{c}\text { India to S. } \\
\text { China \& } \\
\text { Malesia } \\
\text { Jambi } \\
\text { W. Java } \\
\text { Lampung }\end{array}$ & $\begin{array}{c}\text { LC } \\
\text { (Barstow, } \\
\text { 2018) }\end{array}$ & $\begin{array}{l}\text { VIII.B.215; } \\
\text { IX.A.11; } \\
\text { XVIII.B.38- } \\
\text { 38a; I.I.80; } \\
\text { VII.C.82a-82b; } \\
\text { VIII.B. 70a- } \\
\text { 70b-70c }\end{array}$ \\
\hline Menispermaceae & $\begin{array}{l}\text { Cocculus orbiculatus } \\
\text { (L.) DC. }\end{array}$ & Cincau cina & $\begin{array}{c}\text { HepG2 } \\
\text { Hep3B } \\
\text { MCF7 } \\
\text { MDA-MB-231 }\end{array}$ & Subfraction & $\begin{array}{c}0.6 \\
0.75 \\
2.0 \\
1.2\end{array}$ & $\begin{array}{l}\text { (Chang et al. } \\
\text { 2005) }\end{array}$ & $\begin{array}{c}\text { I.A } \\
\text { Contains (+)-isotrilobine } \\
\text { and (-)-sinococuline }\end{array}$ & W. Sumatra & N/A & VI.D.151. \\
\hline Menispermaceae & $\begin{array}{c}\text { Stephania } \\
\text { hernandifolia (Wiild.', } \\
\text { Walp. }\end{array}$ & $\begin{array}{l}\text { Areuy } \\
\text { geureung, } \\
\text { tayungan }\end{array}$ & $\mathrm{KB}$ & N/A & N/A & $\begin{array}{l}\text { (Semwal et al. } \\
\text { 2010) }\end{array}$ & $\begin{array}{l}\text { IV. Contains dl-tetrandrine, } \\
\text { fangchinoline, d- } \\
\text { tetrandrine, and d- } \\
\text { isochondrodendrine }\end{array}$ & N/A & N/A & CL.73. \\
\hline Moraceae & $\begin{array}{l}\text { Artocarpus altilis } \\
\text { (Parkinson ex } \\
\text { F.A.Zorn) }\end{array}$ & Sukun & HeLa & Crude & 40 & $\begin{array}{l}\text { (Ganeson et al. } \\
\text { 2018) }\end{array}$ & II & Papua & N/A & VII.B.141. \\
\hline
\end{tabular}




\begin{tabular}{|c|c|c|c|c|c|c|c|c|c|c|}
\hline Moraceae & $\begin{array}{l}\text { Artocarpus elasticus } \\
\text { Reinw. Ex Blume }\end{array}$ & Benda, bendho & $\begin{array}{l}\text { A549 } \\
\text { Hep3B } \\
\text { HT-29 } \\
\text { MCF7 }\end{array}$ & Subfraction & $\begin{array}{l}1.1 \\
3.2 \\
3.1 \\
2.7\end{array}$ & $\begin{array}{l}\text { (Ko et al. } \\
2005)\end{array}$ & $\begin{array}{c}\text { I.A } \\
\text { Contains artelastoxanthone } \\
\text { and artonol A }\end{array}$ & $\begin{array}{l}\text { Kaliman-tan } \\
\text { W. Java } \\
\text { Bengkulu } \\
\text { C. Sulawesi }\end{array}$ & $\begin{array}{l}\text { LC (BGCI } \\
\text { and IUCN, } \\
2018)\end{array}$ & $\begin{array}{l}\text { VIII.C. } 18,25 ; \\
\text { VII.B.69; } \\
\text { VI.E.188; } \\
\text { XI.A.61 }\end{array}$ \\
\hline Moraceae & $\begin{array}{c}\text { Artocarpus } \\
\text { heterophyllus Lam. }\end{array}$ & Nangka & A549 & Crude & 35.27 & $\begin{array}{l}\text { (Patel and } \\
\text { Patel 2011) }\end{array}$ & II & Java & N/A & $\begin{array}{l}\text { VII.C.5; } \\
\text { VIII.B. } 218 ; \\
\text { XI.A.8. }\end{array}$ \\
\hline Moraceae & $\begin{array}{c}\text { Artocarpus } \\
\text { lanceifolius Roxb. }\end{array}$ & Kaleang & P388 & Subfraction & 1.7 & $\begin{array}{l}\text { (Hakim et al. } \\
\text { 2002) }\end{array}$ & $\begin{array}{c}\text { I.B. Contains } \\
\text { Artoindonesianin P, } \\
\text { artobiloxanthone, and } \\
\text { cycloartobilo-xanthone }\end{array}$ & C. Sulawesi & N/A & VII.B.120 \\
\hline Moraceae & Ficus benjamina $\mathrm{L}$. & Beringin & $\mathrm{MCF}$ & Crude & 133 & $\begin{array}{l}\text { (Subarnas et } \\
\text { al. 2012) }\end{array}$ & III & Trop. Asia & $\begin{array}{l}\text { LC (BGCI } \\
\text { and IUCN, } \\
2019)\end{array}$ & $\begin{array}{l}\text { VI.C.76; } \\
\text { XIII.A.43; } \\
\text { XIII.B.53. }\end{array}$ \\
\hline Moraceae & Ficus deltoidea Jack. & Tabat barito & DU-145 & Crude & 93.11 & $\begin{array}{l}\text { (Soib et al. } \\
\text { 2015) }\end{array}$ & II & W. Java & N/A & $\begin{array}{l}\text { II.C. } 25 b, 39 \text {, } \\
\text { 53-53a; VII. } \\
\text { B.189-189a. }\end{array}$ \\
\hline Moraceae & $\begin{array}{l}\text { Ficus drupacea } \\
\text { Thunb. }\end{array}$ & $\begin{array}{l}\text { Ara coklat-wol, } \\
\text { kowang }\end{array}$ & $\begin{array}{c}\text { HeLa } \\
\text { MCF7 } \\
\text { Jurkat } \\
\text { HT-29 } \\
\text { T24 }\end{array}$ & Subfraction & $\begin{array}{l}15.16 \pm 1.6 \\
16.28 \pm 1.3 \\
19.64 \pm 2.6 \\
25.58 \pm 1.3 \\
12.81 \pm 1.4\end{array}$ & $\begin{array}{l}\text { (Yessoufou } \\
\text { 2015) }\end{array}$ & $\begin{array}{l}\text { II. Contains oleanolic acid, } \\
\text { friedelin, and epilupeol } \\
\text { acetate }\end{array}$ & W. Sumatra & $\begin{array}{l}\text { LC (BGCI } \\
\text { and IUCN, } \\
2018)\end{array}$ & II.C.34. \\
\hline Moraceae & $\begin{array}{l}\text { Ficus fistulosa } \\
\text { Reinw. ex Blume }\end{array}$ & Ara, beunying & $\begin{array}{l}\text { MDA-MB-468, } \\
\text { MDA-MB-231, } \\
\text { MCF7, MCF10A }\end{array}$ & Crude & $\begin{array}{l}0.015 \\
0.191 \\
0.362 \\
4.259\end{array}$ & $\begin{array}{l}\text { (Al- } \\
\text { Khdhairawi et } \\
\text { al. 2017) }\end{array}$ & $\begin{array}{c}\text { I.A } \\
\text { Contains (-) } \\
\text { tengechlorenine }\end{array}$ & $\begin{array}{c}\text { Jambi } \\
\text { Java, } \\
\text { Sumatra } \\
\text { W. Java }\end{array}$ & $\begin{array}{l}\text { LC (Shao } \\
\text { et al., } \\
2019)\end{array}$ & $\begin{array}{c}\text { II.C.45; } \\
\text { VII.C.266- } \\
\text { 266a; VII.C. } \\
\text { 67-67a; } \\
\text { VIII.B.40-40a; } \\
\text { X.B.8. }\end{array}$ \\
\hline Moraceae & Ficus hirta Vahl. & Gegedanganara & HeLa & Crude & $>1000$ & $\begin{array}{l}\text { (Zeng et al. } \\
\text { 2012) }\end{array}$ & III & S. Sumatra & N/A & $\begin{array}{l}\text { II.C. } 49 a-49 b- \\
49 c .\end{array}$ \\
\hline Moraceae & Ficus religiosa $\mathrm{L}$. & Ara & A549 & N/A & 200 & $\begin{array}{l}\text { (Sankar et al. } \\
\text { 2014) }\end{array}$ & $\begin{array}{l}\text { IV. Engineered with copper } \\
\text { oxide nanoparticle }\end{array}$ & Srilangka & N/A & I.C.35-35b. \\
\hline Moraceae & Ficus septica Burm.f & Awar-awar & $\mathrm{T}-47 \mathrm{D}$ & Crude & 9.3 & $\begin{array}{c}\text { (Nugroho et al. } \\
\text { 2013) }\end{array}$ & I.D & $\begin{array}{l}\text { Malesia } \\
\text { W. Java } \\
\text { W. Sumatra }\end{array}$ & $\begin{array}{l}\text { LC (BGCI } \\
\text { and IUCN, } \\
2019)\end{array}$ & $\begin{array}{l}\text { II.C. } 14 ; \\
\text { II.C. } 41 ; \\
\text { II.C. } 37 ;\end{array}$ \\
\hline Moraceae & Morus alba $\mathrm{L}$. & White mulberry & $\begin{array}{l}\text { HL-60 } \\
\text { CRL1579 }\end{array}$ & Subfraction & $\begin{array}{l}0.95 \\
5.56\end{array}$ & $\begin{array}{l}\text { (Kikuchi et al. } \\
\text { 2010) }\end{array}$ & $\begin{array}{c}\text { I.B } \\
\text { Contains albanol A }\end{array}$ & China & N/A & XV.A.25. \\
\hline Moraceae & Morus nigra L. & Blackberry & MCF7 & Crude & $575 \pm 15$ & $\begin{array}{l}\text { (Ahmed et al. } \\
\text { 2016) }\end{array}$ & III & Temp. Asia & N/A & III.C.16. \\
\hline Musaceae & $\begin{array}{c}\text { Musa acuminata } \\
\text { Colla }\end{array}$ & Pisang & $\begin{array}{l}\text { HePG2 } \\
\text { MCF7 } \\
\text { EACC }\end{array}$ & Crude & 58.06 & $\begin{array}{l}\text { (Abou-Elella } \\
\text { and Mourad } \\
\text { 2015; Salama } \\
\text { et al. 2020) }\end{array}$ & II & W. Java & N/A & $\begin{array}{l}\text { I.A.90-90a, } \\
107-107 a, 108 .\end{array}$ \\
\hline
\end{tabular}




\begin{tabular}{|c|c|c|c|c|c|c|c|c|c|c|}
\hline Myricaceae & $\begin{array}{c}\text { Myrica esculenta } \\
\text { Buch.-Ham. ex D. } \\
\text { Don }\end{array}$ & $\begin{array}{c}\text { Bayberry, } \\
\text { kaphal }\end{array}$ & $\begin{array}{c}\text { HepG2, } \\
\text { Hela } \\
\text { MDA-MB-231 }\end{array}$ & Crude & $>1000$ & $\begin{array}{c}\text { (Shod and Shri } \\
\text { 2018) }\end{array}$ & III & W. Java & N/A & $\begin{array}{l}\text { VIII.B.108- } \\
108 \mathrm{a}, 149 .\end{array}$ \\
\hline Myricaceae & $\begin{array}{l}\text { Myrica rubra (Lour.) } \\
\text { Siebold and Zucc. }\end{array}$ & $\begin{array}{l}\text { Yangmei, } \\
\text { bayberry } \\
\text { jepang }\end{array}$ & $\mathrm{Ca}-\mathrm{Co} 2$ & Subfraction & $24.4 \pm 2.4$ & $\begin{array}{c}\text { (Ambrož et al. } \\
\text { 2015) }\end{array}$ & $\begin{array}{c}\text { II } \\
\text { Contains } \alpha \text {-humulene }\end{array}$ & China, Japan & N/A & $\begin{array}{l}\text { III.C.63-63a; } \\
\text { XI.A.31. }\end{array}$ \\
\hline Myrtaceae & $\begin{array}{l}\text { Callistemon citrinus } \\
\text { (Curtis) Skeels }\end{array}$ & Sikat botol & MCF7 & Crude & 2.29 & $\begin{array}{c}\text { (Fayemi et al. } \\
\text { 2019) }\end{array}$ & I.D & Australia & N/A & $\begin{array}{c}\text { I.G.19; II.C. 6; } \\
\text { III.C.41-41a; } \\
\text { IV.C. 23; } \\
\text { IV.E.4; } \\
\text { VI.C.18; } \\
\text { VII.C.4 }\end{array}$ \\
\hline Myrtaceae & $\begin{array}{l}\text { Eucalyptus globulus } \\
\text { Labill. }\end{array}$ & $\begin{array}{l}\text { Gum biru } \\
\text { selatan }\end{array}$ & A549 & Crude & N/A & (Adnan 2019) & IV & China & $\begin{array}{c}\text { LC } \\
\text { (Fensham } \\
\text { et al, } \\
\text { 2019) }\end{array}$ & III.F.55-55a. \\
\hline Myrtaceae & $\begin{array}{c}\text { Eucalyptus } \\
\text { microcorys F.Muell. }\end{array}$ & Kayu pohon & MIA-PaCa2 & Crude & $\begin{array}{c}93.11 \pm 3.43 \\
\mu \mathrm{g} / \mathrm{mL}\end{array}$ & $\begin{array}{c}\text { (Bhuyan et al. } \\
\text { 2018) }\end{array}$ & II & Australia & $\begin{array}{c}\text { NT } \\
\text { (Fensham et } \\
\text { al, 2019) }\end{array}$ & $\begin{array}{l}\text { III.F.33a-33b- } \\
\text { 33c; VII.A.2a- } \\
\text { 2b; XI.A.38; } \\
\text { XIII.A.39. }\end{array}$ \\
\hline Myrtaceae & $\begin{array}{c}\text { Eucalyptus robusta } \\
\text { Sm. }\end{array}$ & & $\begin{array}{c}\text { HT-29 } \\
\text { U87 } \\
\text { SJ-G2 } \\
\text { SMA } \\
\text { MCF7 }\end{array}$ & Crude & $\begin{array}{c}77 \pm 2.0 \\
183 \pm 8.7 \\
79 \pm 5.6 \\
100 \pm 5.0 \\
124 \pm 4.5\end{array}$ & $\begin{array}{l}\text { (Vuong et al. } \\
\text { 2015) }\end{array}$ & II & $\begin{array}{l}\text { New S. } \\
\text { Wales }\end{array}$ & $\begin{array}{c}\text { NT } \\
\text { (Fensham et } \\
\text { al, 2019) }\end{array}$ & $\begin{array}{c}\text { VII.A.15, 28- } \\
\text { 28a-28b, 68; } \\
\text { VII.B.41; } \\
\text { XIII.A.38-38e. }\end{array}$ \\
\hline & & N/A & $\begin{array}{c}\text { MCF10A } \\
\text { A2780 } \\
\text { H460 } \\
\text { A431 } \\
\text { DU-145 } \\
\text { BE2-C241 } \\
\text { MIA-PaCa2 }\end{array}$ & & $\begin{array}{c}130 \pm 5.2 \\
80 \pm 3.0 \\
77 \pm 3.0 \\
98 \pm 7.8 \\
113 \pm 5.5 \\
77 \pm 4.6 \\
129 \pm 5.8\end{array}$ & & & & & \\
\hline Myrtaceae & $\begin{array}{c}\text { Decaspermum } \\
\text { fruticosum J.R.Forst. } \\
\text { and G.Forst. }\end{array}$ & Ipis kulit & MCF & Crude & 154 & $\begin{array}{l}\text { (Subarnas et } \\
\text { al. 2012) }\end{array}$ & III & W. Java & N/A & $\begin{array}{l}\text { VI.E.97; } \\
\text { XI.C. } 28 ; \\
\text { XV.A. } 17 .\end{array}$ \\
\hline Myrtaceae & Eugenia uniflora L. & Dewandaru & $\begin{array}{c}\text { T-47D } \\
\text { DU-145 } \\
\text { JIMT-1 } \\
\text { MIA-PaCa2 }\end{array}$ & Crude & $\begin{array}{c}65 \\
166.9 \pm 3.9 \\
156.6 \pm 4.8 \\
219.2 \pm 7.8\end{array}$ & $\begin{array}{l}\text { (Ismiyati et al. } \\
\text { 2012; Alade- } \\
\text { sanmi et al. } \\
\text { 2019) }\end{array}$ & II & $\begin{array}{c}\text { Trop. } \\
\text { America }\end{array}$ & N/A & XIV.A.55-55a. \\
\hline Myrtaceae & $\begin{array}{l}\text { Melaleuca } \\
\text { alternifolia (Maiden } \\
\text { and Betche) Cheel }\end{array}$ & Tea tree & HT-29 & Crude & 12.5 & $\begin{array}{c}\text { (Byahatti et al. } \\
\text { 2018) }\end{array}$ & I.D & Australia & N/A & $\begin{array}{l}\text { I.A.32a; } \\
\text { IV.E.15; } \\
\text { VII.C.77d; } \\
\text { VIII.A.4. }\end{array}$ \\
\hline
\end{tabular}




\begin{tabular}{|c|c|c|c|c|c|c|c|c|c|c|}
\hline Myrtaceae & $\begin{array}{l}\text { Psidium cattleianum } \\
\text { Afzel. ex Sabine }\end{array}$ & $\begin{array}{l}\text { Strawberry } \\
\text { guava }\end{array}$ & $\begin{array}{l}\text { HepG2, } \\
\text { AGS, } \\
\text { HeLa, } \\
\text { SNU-1, } \\
\text { SNU-16 }\end{array}$ & Subfraction & $\begin{array}{l}0.81 \\
2.51 \\
2.76 \\
3.43 \\
5.59\end{array}$ & $\begin{array}{c}\text { (Jun et al. } \\
\text { 2011) }\end{array}$ & $\begin{array}{c}\text { I.A } \\
\text { Contains } \beta \text {-caryophyllene } \\
\text { oxide and quercetin }\end{array}$ & Brazil & N/A & I.K.51. \\
\hline Myrtaceae & Psidium guajava $\mathrm{L}$. & Jambu biji & $\begin{array}{l}\text { KBM5 } \\
\text { SCC4 } \\
\text { U266 }\end{array}$ & Crude & $\begin{array}{l}22.73 \pm 2.55 \\
22.82 \pm 2.36 \\
20.97 \pm 4.39\end{array}$ & $\begin{array}{c}\text { (Ashraf et al. } \\
\text { 2016) }\end{array}$ & II & $\begin{array}{l}\text { Trop. } \\
\text { America }\end{array}$ & $\begin{array}{c}\text { LC } \\
\text { (Canteiro \& } \\
\text { Lucas,. } \\
\text { 2019) }\end{array}$ & I.K.10. \\
\hline Myrtaceae & $\begin{array}{c}\text { Rhodamnia cinerea } \\
\text { Jack }\end{array}$ & $\mathrm{Ki}$ beusi & MCF7 & Crude & 150 & $\begin{array}{l}\text { (Subarnas et } \\
\text { al. 2012) }\end{array}$ & III & W. Java & $\begin{array}{l}\text { LC (BGCI } \\
\text { and IUCN, } \\
2018)\end{array}$ & $\begin{array}{l}\text { VII.C.184; } \\
\text { VIII.B.168, } \\
\text { 331; XVIII. } \\
\text { B.31-31a; } \\
\text { XX.A.24. }\end{array}$ \\
\hline Myrtaceae & $\begin{array}{l}\text { Syzygium cumini (L.) } \\
\text { Skeels }\end{array}$ & Black plum & A549 & Crude & $59 \pm 4$ & $\begin{array}{l}\text { (Aqil et al. } \\
\text { 2012) }\end{array}$ & II & Java & $\begin{array}{l}\text { LC (BGCI } \\
\text { and IUCN, } \\
2019)\end{array}$ & $\begin{array}{l}\text { VIII.B.85, } \\
\text { 235-235a. }\end{array}$ \\
\hline Myrtaceae & $\begin{array}{l}\text { Syzygium jambos (L.) } \\
\text { Alston }\end{array}$ & $\begin{array}{l}\text { Jambu mawar, } \\
\text { Malabar plum }\end{array}$ & $\begin{array}{l}\text { HeLa } \\
\text { A431 } \\
\text { A375 }\end{array}$ & Crude & $\begin{array}{c}56.20 \pm 3.00 \\
54.70 \pm 0.60 \\
198.00 \pm 3.00\end{array}$ & $\begin{array}{c}\text { (Twilley et al. } \\
\text { 2017) }\end{array}$ & II & $\begin{array}{l}\text { Jambi } \\
\text { W. Java }\end{array}$ & $\begin{array}{l}\text { LC (BGCI } \\
\text { and IUCN, } \\
\text { 2019) }\end{array}$ & $\begin{array}{l}\text { VII.B.80-80a; } \\
\text { III.E. 54-54a; } \\
\text { XIX.C. } 38 \text {. }\end{array}$ \\
\hline Myrtaceae & $\begin{array}{l}\text { Syzygium polyanthum } \\
\text { (Wight) Walp. }\end{array}$ & Salam & $\begin{array}{c}4 \mathrm{~T} 1 \\
\text { MCF7 }\end{array}$ & Crude & $\begin{array}{l}672.6 \pm 59.4 \\
126.1 \pm 50.9\end{array}$ & $\begin{array}{l}\text { (Nordin et al. } \\
\text { 2019) }\end{array}$ & III & W. Sumatra & N/A & VII.C.375. \\
\hline Oleaceae & Olea europaea L. & Zaitun & $\begin{array}{c}\text { T24 } \\
\text { MCF7 }\end{array}$ & Subfraction & $\begin{array}{l}4.09 \\
2.59\end{array}$ & $\begin{array}{l}\text { (Goulas et al. } \\
\text { 2009) }\end{array}$ & $\begin{array}{c}\text { I.B } \\
\text { Contains luteolin, } \\
\text { oleuropein, and } \\
\text { hydroxytyrosol }\end{array}$ & Libya & N/A & $\begin{array}{l}\text { I.A. } 105 \text {; } \\
\text { I.K. } 198 \text {. }\end{array}$ \\
\hline Passifloraceae & $\begin{array}{c}\text { Passiflora suberosa } \\
\text { L. }\end{array}$ & $\begin{array}{c}\text { Markisa, } \\
\text { konyal }\end{array}$ & $\begin{array}{l}\text { HCT-116 } \\
\text { OVACAR-8 } \\
\text { SF-295 }\end{array}$ & Crude & N/A & (Amaral 2019) & $\begin{array}{c}\text { III } \\
\text { Growth Inhibition Index } \\
<50 \%\end{array}$ & $\begin{array}{l}\text { Trop. } \\
\text { America }\end{array}$ & N/A & III.D.22. \\
\hline Pentaphylacaceae & $\begin{array}{c}\text { Ternstroemia } \\
\text { gymnanthera (Wight } \\
\text { and Arn.) Sprague }\end{array}$ & N/A & N/A & N/A & N/A & $\begin{array}{l}\text { (Ikuta et al. } \\
2003 ; \\
\text { Venkatesan et } \\
\text { al. 2017) }\end{array}$ & IV & Java & N/A & IV.A.17. \\
\hline Phyllanthaceae & $\begin{array}{l}\text { Glochidion } \\
\text { eriocarpum Champ. } \\
\text { Ex Benth. }\end{array}$ & N/A & $\begin{array}{c}\text { HL-60 } \\
\text { HT-29 } \\
\text { MCF7 } \\
\text { SK-OV-3 }\end{array}$ & Subfraction & $\begin{array}{c}4.92 \\
6.09 \\
26.04 \\
14.32\end{array}$ & $\begin{array}{l}\text { (Kiem et al. } \\
\text { 2009) }\end{array}$ & $\begin{array}{l}\text { II. Contains glochieriosides } \\
\qquad \text { A and B }\end{array}$ & Papua & N/A & $\begin{array}{l}\text { VII.B.116- } \\
116 \mathrm{a} .\end{array}$ \\
\hline Phyllanthaceae & $\begin{array}{c}\text { Glochidion } \\
\text { zeylanicum (Gaertn.) } \\
\text { A.Juss. }\end{array}$ & N/A & $\begin{array}{l}\text { HEK293 } \\
\text { HepG2 } \\
\text { PC-3 }\end{array}$ & Crude & $\begin{array}{c}66.6 \\
2.99 \\
12.25\end{array}$ & $\begin{array}{c}\text { (Sharma et al. } \\
\text { 2011) }\end{array}$ & I.C & Jambi & $\begin{array}{l}\text { LC (Ye, } \\
\text { BGCI \& } \\
\text { IUCN, } \\
2019)\end{array}$ & IX.B.9. \\
\hline
\end{tabular}




\begin{tabular}{|c|c|c|c|c|c|c|c|c|c|c|}
\hline Phyllanthaceae & $\begin{array}{c}\text { Phyllanthus emblica } \\
\text { L. }\end{array}$ & $\begin{array}{c}\text { Kimalaka, } \\
\text { malaka, } \\
\text { kemloko }\end{array}$ & MCF7 & Crude & 54 & $\begin{array}{c}\text { (Ponraj and } \\
\text { Kannan 2014) }\end{array}$ & II & W. Java & N/A & $\begin{array}{l}\text { VII.C.144- } \\
\text { 144a-144b, } \\
\text { 271-271a. }\end{array}$ \\
\hline Pinaceae & $\begin{array}{c}\text { Pinus kesiya Royle } \\
\text { ex Gordon }\end{array}$ & $\begin{array}{l}\text { Pinus khasi, } \\
\text { pinus benguet, } \\
\text { pinus tiga } \\
\text { jarum }\end{array}$ & $\begin{array}{l}\text { U937 } \\
\text { HepG2 }\end{array}$ & Crude & $\begin{array}{r}299.0 \pm 5.2 \\
52.0 \pm 5.8\end{array}$ & $\begin{array}{l}\text { (Weerapree- } \\
\text { yakul et al. } \\
\text { 2016) }\end{array}$ & II & $\begin{array}{l}\text { Himalaya to } \\
\text { S. E. Asia }\end{array}$ & $\begin{array}{c}\text { LC } \\
\text { (Farjon, } \\
\text { 2013) }\end{array}$ & $\begin{array}{l}\text { III.B.3a-3b; } \\
\text { IV.F.2; XI. } \\
\text { A.13-13a; } \\
\text { XIII.B.23-23a; } \\
\text { XIV.B.34. }\end{array}$ \\
\hline Pinaceae & $\begin{array}{l}\text { Pinus merkusii } \\
\text { Jungh. \& de Vriese }\end{array}$ & Pinus, tusam & $\mathrm{HeLa}$ & Crude & 384.10 & $\begin{array}{l}\text { (Proboning-rat } \\
\text { et al. } 2019\end{array}$ & III & Aceh & $\begin{array}{c}\text { VU } \\
\text { (Farjon, } \\
\text { 2013) }\end{array}$ & $\begin{array}{l}\text { XIV.B. } 38-38 b- \\
\text { 38c. }\end{array}$ \\
\hline Pinaceae & $\begin{array}{l}\text { Pinus parviflora } \\
\text { Siebold \& Zucc. }\end{array}$ & $\begin{array}{c}\text { Japanese White } \\
\text { Pine }\end{array}$ & $\begin{array}{l}\text { L929 } \\
\text { ML-1 }\end{array}$ & Subfraction & N/A & $\begin{array}{l}\text { (Hanaoka at } \\
\text { al., 1989) }\end{array}$ & IV & $\begin{array}{l}\text { Formosa, } \\
\text { Japan }\end{array}$ & $\begin{array}{l}\text { LC 9 } \\
\text { Farjon, } \\
\text { 2013) }\end{array}$ & $\begin{array}{l}\text { V.C. } 25-25 \mathrm{a} ; \\
\text { XIII.B.3-3a. }\end{array}$ \\
\hline Pinaceae & $\begin{array}{c}\text { Pinus yunnanensis } \\
\text { Franch. }\end{array}$ & Pinus yunnan & $\begin{array}{l}\text { HL-60, SMMC- } \\
\text { 7721, A549, } \\
\text { MCF7, SW-480 }\end{array}$ & Subfraction & N/A & $\begin{array}{l}\text { (Lei et al, } \\
\text { 2011) }\end{array}$ & $\begin{array}{c}\text { III } \\
\text { Contains planchol E }\end{array}$ & $\begin{array}{l}\text { S. and W. } \\
\text { China }\end{array}$ & $\begin{array}{c}\text { LC } \\
\text { (Farjonet } \\
\text { al., 2013) }\end{array}$ & II.B.14. \\
\hline Piperaceae & Piper aduncum L. & $\begin{array}{c}\text { Seuseureuhansi } \\
\text { rihan }\end{array}$ & HeLa & Crude & 3.91 & $\begin{array}{c}\text { (Wahyu et al, } \\
\text { 2013) }\end{array}$ & I.C & Peru & $\begin{array}{l}\text { LC (BGCI, } \\
\text { IUCN and } \\
\text { Lorea, } \\
\text { 2019) }\end{array}$ & IV.A. 27. \\
\hline Plantaginaceae & $\begin{array}{c}\text { Plantago lanceolata } \\
\text { L. }\end{array}$ & Toucan & $\begin{array}{l}\text { MCF7 } \\
\text { AMJ13 } \\
\text { MDA-MB } \\
\text { CAL51 }\end{array}$ & Crude & $\begin{array}{c}674 \\
7200 \\
250 \\
23.7\end{array}$ & $\begin{array}{c}\text { (Alsaraf et al. } \\
\text { 2019) }\end{array}$ & II & Europe & N/A & III.D.30. \\
\hline Poaceae & Coix lacryma-jobi $\mathrm{L}$. & Jali & НТ-29 & Crude & $11.61 \pm 0.95$ & $\begin{array}{l}\text { (Manosroi et } \\
\text { al. 2016) }\end{array}$ & I.D & Trop. Asia & N/A & I.G.35. \\
\hline Poaceae & $\begin{array}{l}\text { Phyllostachys edulis } \\
\text { (Carriere) J.Houz. }\end{array}$ & Bambu & $\begin{array}{l}\text { Hepa } 6 \\
\text { 3T3-L1 }\end{array}$ & Subfraction & N/A & $\begin{array}{l}\text { (Higa et al. } \\
\text { 2012) }\end{array}$ & $\begin{array}{c}\text { IV. Contains } \\
\text { tricin dan } 7-\mathrm{O}-\text { methyl- } \\
\text { tricin }\end{array}$ & China & N/A & I.L.2-2a. \\
\hline Poaceae & $\begin{array}{l}\text { Phyllostachys nigra } \\
\text { (Lodd. ex Lindl.) } \\
\text { Munro }\end{array}$ & Bambu hitam & $\begin{array}{c}\text { A375 } \\
\text { L929 } \\
\text { HeLa } \\
\text { THP-1 }\end{array}$ & Subfraction & $\begin{array}{l}26.27 \\
15.77 \\
27.62 \\
24.78\end{array}$ & $\begin{array}{l}\text { (Lu et al. } \\
\text { 2010) }\end{array}$ & $\begin{array}{c}\text { II } \\
\text { Contain friedelin }\end{array}$ & China & N/A & IV.C.31. \\
\hline Podocarpaceae & $\begin{array}{l}\text { Podocarpus } \\
\text { macrophyllus } \\
\text { (Thunb.) Sweet }\end{array}$ & $\begin{array}{l}\text { Luhansung, } \\
\text { kusamak }\end{array}$ & $\begin{array}{c}\text { HeLa } \\
\text { AGS } \\
\text { MDA-MB-231 } \\
\text { HepG2 }\end{array}$ & Subfraction & $\begin{array}{l}0.18 \\
0.11 \\
0.23 \\
0.98\end{array}$ & (Qi et al. 2018) & $\begin{array}{l}\text { I.A. Contains } 2,3 \text {-dihydro- } \\
2 \beta \text {-hydroxypodolid, } \\
\text { inumakilactone B , } 2 \beta \text { - } \\
\text { hydroxy-nagilactone F, and } \\
\text { nagilactone } F\end{array}$ & China, Japan & $\begin{array}{c}\text { LC } \\
\text { (Farjon, } \\
\text { 2013) }\end{array}$ & XV.A.7. \\
\hline
\end{tabular}




\begin{tabular}{|c|c|c|c|c|c|c|c|c|c|c|}
\hline Polygonaceae & $\begin{array}{l}\text { Coccoloba uvifera } \\
\text { (L.) L. }\end{array}$ & N/A & LNCaP & Crude & N/A & $\begin{array}{l}\text { (Fort et al. } \\
\text { 2018) }\end{array}$ & IV & $\begin{array}{c}\text { Trop. } \\
\text { America } \\
\text { Venezuela }\end{array}$ & $\begin{array}{l}\text { LC (IUCN } \\
\text { and BGCI, } \\
2020 \text { ) }\end{array}$ & $\begin{array}{l}\text { VI.D.73-73a; } \\
\text { VI.D. 97-97a- } \\
\text { 97b. }\end{array}$ \\
\hline Primulaceae & Ardisia crenata Sims & $\begin{array}{l}\text { Mata ayam, } \\
\text { coral berry }\end{array}$ & HepG2 & Crude & $145 \pm 13$ & $\begin{array}{l}\text { (Newell et al, } \\
\text { 2010) }\end{array}$ & III & $\begin{array}{l}\text { China, E. } \\
\text { Malesia } \\
\text { W. Java }\end{array}$ & N/A & $\begin{array}{l}\text { I.D.10-10a; } \\
\text { I.E.5-5a-5b; } \\
\text { I.G.154; IV. } \\
\text { A. } 92\end{array}$ \\
\hline Primulaceae & $\begin{array}{l}\text { Ardisia crispa } \\
\text { (Thunb.) A.DC. }\end{array}$ & Christmas berry & $\begin{array}{l}\text { MCF7 } \\
4 \mathrm{~T} 1\end{array}$ & Crude & $\begin{array}{c}54.98 \pm 14.10 \\
42.26 \pm 1.82\end{array}$ & $\begin{array}{l}\text { (Nordin et al. } \\
2017 ; 2018 \text { ) }\end{array}$ & II & $\begin{array}{l}\text { Jambi } \\
\text { S. Sumatra } \\
\text { W. Java }\end{array}$ & N/A & $\begin{array}{l}\text { VII.C. } 115 ; \\
\text { VII.C. } 158- \\
158 \mathrm{a}\end{array}$ \\
\hline Primulaceae & Embelia ribes Burm.1 & $\begin{array}{c}\text { Kicemang } \\
\text { beurit }\end{array}$ & $\mathrm{HeLa}$ & Crude & 429.99 & $\begin{array}{l}\text { (Arbiastutie et } \\
\text { al. 2017, } \\
\text { Chanchal et al. } \\
\text { 2018) }\end{array}$ & III & S. Sumatra & N/A & VI.E.157. \\
\hline Primulaceae & $\begin{array}{l}\text { Marantodes pumilum } \\
\text { (Blume) Kuntze }\end{array}$ & N/A & $\begin{array}{l}\text { MCF7 } \\
\text { HT-29 }\end{array}$ & Crude & $\begin{array}{l}46.82 \pm 2.41 \\
44.62 \pm 2.11\end{array}$ & $\begin{array}{l}\text { (Karimi et al, } \\
\text { 2016) }\end{array}$ & II & W. Java & N/A & $\begin{array}{l}\text { VII.C.286a, } \\
\text { 434-434a. }\end{array}$ \\
\hline Pteridaceae & $\begin{array}{l}\text { Pityrogramma } \\
\text { calomelanos }(\mathrm{L} .) \\
\text { Link }\end{array}$ & Paku perak & P388 & Subfraction & 1.6 & $\begin{array}{l}\text { (Najihah et al. } \\
\text { 2014; Suyatno } \\
\text { et al, 2014 ) }\end{array}$ & $\begin{array}{c}\text { I.B } \\
\text { Contains 2',6'-dihydroxy- } \\
\text { 4'-- } \\
\text { methoxydihydrochalcone, } \\
\text { kaempferol, and quercetine }\end{array}$ & N/A & N/A & PT.64. \\
\hline Rhamnaceae & $\begin{array}{l}\text { Colletia paradoxa } \\
\text { (Spreng.) Escal. }\end{array}$ & N/A & $\begin{array}{c}\text { HT-29 } \\
\text { NCI-H460 }\end{array}$ & Crude & $\begin{array}{l}96 \\
93\end{array}$ & $\begin{array}{l}\text { (Monks et al. } \\
\text { 2002) }\end{array}$ & II & $\begin{array}{l}\text { S. Brazil - } \\
\text { Uruguay }\end{array}$ & N/A & $\begin{array}{l}\text { I.D.76-76a, } \\
\text { 80a. }\end{array}$ \\
\hline Rhamnaceae & Ziziphus jujuba Mill & Jujube & MD-MB-468 & Crude & 0.0005 & $\begin{array}{l}\text { (Hosyar et al. } \\
2015 \text { Iqbal et } \\
\text { al. 2017) }\end{array}$ & I.B & W. Java & $\begin{array}{l}\text { LC } \\
\text { (IUCN, } \\
\text { 2007) }\end{array}$ & VII.C.235. \\
\hline Rhamnaceae & $\begin{array}{l}\text { Ziziphus oenopolia } \\
\text { (L.) Mill }\end{array}$ & Kuku heulang & N/A & N/A & N/A & $\begin{array}{c}\text { (Shukla et al. } \\
\text { 2016) }\end{array}$ & $\begin{array}{c}\text { IV } \\
\text { Contains betulinic acid }\end{array}$ & $\begin{array}{c}\text { Jambi } \\
\text { Asia, } \\
\text { Australia } \\
\text { W. Java }\end{array}$ & $\begin{array}{l}\text { LC (Ye, J. } \\
\text { et al, } \\
2019)\end{array}$ & $\begin{array}{l}\text { IX.C. } 2 ; \\
\text { VII.C.102; } \\
\text { VIII.B.198. }\end{array}$ \\
\hline Rosaceae & $\begin{array}{l}\text { Eriobotrya japonica } \\
\text { (Thunb.) Lindl. }\end{array}$ & Biwa, loquat & $\begin{array}{l}\text { HL-60 } \\
\text { CRL1579 }\end{array}$ & Subfraction & $\begin{array}{l}2.28 \\
3.97\end{array}$ & $\begin{array}{l}\text { (Kikuchi et al. } \\
\text { 2011) }\end{array}$ & $\begin{array}{l}\text { I.B. Contains } \delta \text {-oleanolic } \\
\text { acid, ursolic acid, } \\
\text { and betulinic acid }\end{array}$ & China, Japan & N/A & $\begin{array}{l}\text { I.A.44; I.K.5; } \\
\text { XIV. A.31-31a }\end{array}$ \\
\hline Rosaceae & $\begin{array}{l}\text { Sanguisorba minor } \\
\text { Scop. }\end{array}$ & Salad burnet & N/A & N/A & N/A & $\begin{array}{l}\text { (Cuccioloni et } \\
\text { al. 2012) }\end{array}$ & $\begin{array}{l}\text { IV. Contains quercetin-3- } \\
\text { glucuronide }\end{array}$ & $\begin{array}{l}\text { C. Asia, } \\
\text { Europe, } \\
\text { N. Africa }\end{array}$ & N/A & $\begin{array}{c}\text { XV.B.12; } \\
\text { XVI.A.40-40a. }\end{array}$ \\
\hline Rubiaceae & $\begin{array}{c}\text { Coffea canephora } \\
\text { Pierre ex A. Froehner }\end{array}$ & Kopi robusta & HT-29 & Subfraction & N/A & $\begin{array}{l}\text { (Choi et al. } \\
\text { 2015; Mori et } \\
\text { al. 2016) }\end{array}$ & $\begin{array}{c}\text { IV } \\
\text { Contains kahweol, cafestol, } \\
\text { 16-O-methylcafestol }\end{array}$ & Aceh & $\begin{array}{l}\text { LC (Chad- } \\
\text { burn \& } \\
\text { Davis, } \\
\text { 2017) }\end{array}$ & $\begin{array}{l}\text { VII.C.369- } \\
\text { 369a. }\end{array}$ \\
\hline
\end{tabular}




\begin{tabular}{|c|c|c|c|c|c|c|c|c|c|c|}
\hline Rubiaceae & $\begin{array}{c}\text { Gardenia } \\
\text { jasminoides J.Ellis }\end{array}$ & Kacapiring & MDA-MB-231 & Subfraction & 73.90 & $\begin{array}{l}\text { (Kim et al. } \\
\text { 2011; Lichota } \\
\text { and Gwoz- } \\
\text { dzinski 2018) }\end{array}$ & $\begin{array}{c}\text { II } \\
\text { Contain genipin }\end{array}$ & $\begin{array}{c}\text { E. Indies } \\
\text { China, Japan }\end{array}$ & N/A & $\begin{array}{l}\text { I.F.32-32a; } \\
\text { III.F.46c; } \\
\text { XI.A.3-3a; } \\
\text { XV.A.35-35a- } \\
\text { 35b. }\end{array}$ \\
\hline Rubiaceae & Hamelia patens Jacq. & Fire brush & $\begin{array}{l}\text { MDCK } \\
\mathrm{HeLa} \\
\mathrm{SiHa}\end{array}$ & Crude & $\begin{array}{l}94 \pm 1.7 \\
13 \pm 1.2 \\
22 \pm 1.1\end{array}$ & $\begin{array}{l}\text { (Mena-Rejon } \\
\text { et al. 2009) }\end{array}$ & I.C & Peru & $\begin{array}{c}\text { LC } \\
\text { (Cornejo- } \\
\text { Tenorio, et } \\
\text { al. 2019) }\end{array}$ & XV.A.30-30b. \\
\hline Rutaceae & Citrus medica $\mathrm{L}$. & Jeruk sukade & A357 & Essential oil & 89.1 & $\begin{array}{l}\text { (Menichini et } \\
\text { al. 2010; } \\
\text { Chanchal et al. } \\
\text { 2018) }\end{array}$ & II & Jambi & N/A & IX.A.5-5a. \\
\hline Rutaceae & $\begin{array}{c}\text { Clausena excavata } \\
\text { Burm.f. }\end{array}$ & Daun si cerek & $\begin{array}{l}\text { A549 } \\
\text { HeLa }\end{array}$ & Subfraction & $\begin{array}{l}5.25 \\
1.91\end{array}$ & $\begin{array}{l}\text { (Peng et al. } \\
\text { 2013) }\end{array}$ & $\begin{array}{c}\text { I.B } \\
\text { Contains excavatine }\end{array}$ & $\begin{array}{l}\text { Jambi } \\
\text { W. Sumatra }\end{array}$ & N/A & $\begin{array}{c}\text { IX.C.18-18a- } \\
\text { 18d; } \\
\text { IX.A.125- } \\
\text { 125a, 141, } \\
\text { 201-201a. }\end{array}$ \\
\hline Rutaceae & $\begin{array}{l}\text { Murraya paniculata } \\
\text { (L.) Jack }\end{array}$ & Kemuning & HT-29 & Subfraction & 7.91 & $\begin{array}{l}\text { (Jiang et al. } \\
\text { 2016; Shao et } \\
\text { al. 2016) }\end{array}$ & $\begin{array}{c}\text { II } \\
\text { Cancerous cell adhesion } \\
\text { inhibition }\end{array}$ & $\begin{array}{l}\text { Malesia to } \\
\text { Trop. Asia }\end{array}$ & N/A & $\begin{array}{l}\text { IX.A.128- } \\
\text { 128b, } 227 .\end{array}$ \\
\hline Salicaceae & $\begin{array}{l}\text { Flacourtia rukam } \\
\text { Zoll. \& Moritzi }\end{array}$ & Rukam & MCF & Crude & 17 & $\begin{array}{l}\text { (Subarnas et } \\
\text { al. 2012) }\end{array}$ & I.D & $\begin{array}{l}\text { Java } \\
\text { W. Java } \\
\text { Lampung }\end{array}$ & N/A & $\begin{array}{c}\text { VIII.B.12-12b; } \\
\text { XI.C.30; } \\
\text { VIII.B.193; } \\
\text { XI.C.71. }\end{array}$ \\
\hline Sapindaceae & $\begin{array}{l}\text { Dodonaea viscosa } \\
\text { (L.) Jacq. }\end{array}$ & $\begin{array}{l}\text { Hopseed, } \\
\text { cantigi, } \\
\text { cengkeh laut }\end{array}$ & MCF7 & Crude & 19.4 & $\begin{array}{c}\text { (Shafek et al. } \\
\text { 2015) }\end{array}$ & II & $\begin{array}{l}\text { E. Nusa } \\
\text { Tenggara }\end{array}$ & $\begin{array}{l}\text { LC (BGCI } \\
\text { and IUCN, } \\
\text { 2019) }\end{array}$ & V.B.56. \\
\hline Scrophulariaceae & $\begin{array}{l}\text { Buddleja davidii } \\
\text { Franch. }\end{array}$ & Summer lilac & $\begin{array}{l}\text { MGC-803 } \\
\text { Bcap-37 }\end{array}$ & Subfraction & $\begin{array}{c}7.49 \\
11.95\end{array}$ & $\begin{array}{l}\text { (Wu et al. } \\
\text { 2012) }\end{array}$ & $\begin{array}{c}\text { II } \\
\text { Contains colchicine and } \\
\text { luteolin }\end{array}$ & China & N/A & $\begin{array}{l}\text { I.A.20-20a; } \\
\text { III.C. } 17 \text {. }\end{array}$ \\
\hline Smilacaceae & Smilax zeylanica $\mathrm{L}$. & Gadung cina & MCF7 & Crude & $15.49 \pm 1.18$ & $\begin{array}{l}\text { (Uddin et al. } \\
\text { 2015) }\end{array}$ & II & $\begin{array}{l}\text { Ceylon, } \\
\text { Malesia } \\
\text { C. Java } \\
\text { W. Java }\end{array}$ & N/A & $\begin{array}{l}\text { I.B.7; I.I.53; } \\
\text { III.C.56; IX. } \\
\text { A.158-158a; } \\
\text { XVIII.B.32. }\end{array}$ \\
\hline Solanaceae & Capsicum аппиит $\mathrm{L}$. & Paprika merah & N/A & Subfraction & N/A & $\begin{array}{l}\text { (Maoka et al. } \\
\text { 2001) }\end{array}$ & $\begin{array}{l}\text { IV. Contains capsanthin, } \\
\text { capsanthin 3'-ester, and } \\
\text { capsanthin 3,30-diester }\end{array}$ & $\begin{array}{l}\text { Trop. } \\
\text { America }\end{array}$ & $\begin{array}{c}\text { LC } \\
\text { (Aguilar- } \\
\text { Meléndez et } \\
\text { al. 2020) }\end{array}$ & I.G.140. \\
\hline Solanaceae & $\begin{array}{c}\text { Cestrum nocturnum } \\
\text { L. }\end{array}$ & Arum dalu & $\begin{array}{l}\text { CNE-2Z } \\
\text { BEL-7402 } \\
\text { HeLa }\end{array}$ & Subfraction & $\begin{array}{l}17.50 \\
18.71 \\
19.21\end{array}$ & $\begin{array}{l}\text { (Wu et al. } \\
2007 \text { ) }\end{array}$ & II & W. Indies & $\begin{array}{l}\text { LC (BGCI, } \\
\text { IUCN and } \\
\text { Meave, } \\
2019)\end{array}$ & I.D.41 \\
\hline Styracaceae & $\begin{array}{l}\text { Styrax benzoin } \\
\text { Dryand. }\end{array}$ & N/A & N/A & N/A & N/A & $\begin{array}{c}\text { (Du et al. } \\
\text { 2016) }\end{array}$ & IV & $\begin{array}{c}\text { C. Java } \\
\text { N. Sumatra }\end{array}$ & N/A & $\begin{array}{l}\text { I.K.163-163b; } \\
\text { I.K.162. }\end{array}$ \\
\hline
\end{tabular}




\begin{tabular}{|c|c|c|c|c|c|c|c|c|c|c|}
\hline Symplocaceae & $\begin{array}{c}\text { Symplocos } \\
\text { cochinchinensis } \\
\text { (Lour.) S. Moore }\end{array}$ & Kendong & $\begin{array}{l}\text { U87 } \\
\text { HepG2 } \\
\text { MCF7 }\end{array}$ & Crude & $\begin{array}{c}2-10 \\
50-250 \\
10-50\end{array}$ & $\begin{array}{c}\text { (Abida et al. } \\
\text { 2016; } \\
\text { Chanchal et al. } \\
\text { 2018) }\end{array}$ & I.C & $\begin{array}{l}\text { Malay Pen. } \\
\text { W. Java } \\
\text { W. Sumatra }\end{array}$ & N/A & $\begin{array}{c}\text { VIII.B.78; } \\
\text { XVIII.A.15a- } \\
\text { 15b; VIII.B.156; } \\
\text { VII.C.412; } \\
\text { VIII.B.242- } \\
\text { 242a. }\end{array}$ \\
\hline Taxaceae & $\begin{array}{l}\text { Taxus sumatrana } \\
\text { (Miq.) de Laub. }\end{array}$ & $\begin{array}{l}\text { Cemara } \\
\text { sumatra }\end{array}$ & $\begin{array}{c}\text { KB } \\
\text { Hepa } 59 \mathrm{~T} / \mathrm{VGH}\end{array}$ & Subfraction & $\begin{array}{l}0.56 \\
0.10\end{array}$ & $\begin{array}{l}\text { (Shen et al. } \\
\text { 2002) }\end{array}$ & $\begin{array}{c}\text { I.B } \\
\text { Contains taxuspine } \mathrm{F} \text { and } \\
\text { wallifoliol }\end{array}$ & $\begin{array}{l}\text { Sumatra } \\
\text { Jambi } \\
\text { W. Sumatra }\end{array}$ & N/A & $\begin{array}{l}\text { III.A.35-35a- } \\
\text { 35b; II.A.36- } \\
\text { 36a; III.B.22- } \\
\text { 22a, 24; } \\
\text { III.B.34-34a, } \\
37\end{array}$ \\
\hline Theaceae & $\begin{array}{l}\text { Camellia sinensis } \\
\text { (L.) Kuntze }\end{array}$ & Teh hijau & HT-29 & Crude & 87 & $\begin{array}{l}\text { (Hajiaghaali- } \\
\text { pour et al. } \\
2015 ; \\
\text { Chanchal et al. } \\
\text { 2018) }\end{array}$ & II & Japan & $\begin{array}{l}\text { DD } \\
\text { (Rivers } \\
\text { and } \\
\text { Wheeler } \\
\text { 2018) }\end{array}$ & VI.D.65-65b. \\
\hline Theaceae & $\begin{array}{c}\text { Schima wallichii } \\
\text { Choisy }\end{array}$ & Puspa & MCF7 & Crude & 20 & $\begin{array}{l}\text { (Diantini et al. } \\
\text { 2012) }\end{array}$ & I.D & $\begin{array}{c}\text { Bangka } \\
\text { Belitung } \\
\text { W. Sumatra } \\
\text { W. Java }\end{array}$ & $\begin{array}{c}\text { LC } \\
\text { (Oldfield, } \\
\text { 2018) }\end{array}$ & $\begin{array}{l}\text { II.A.54-54a- } \\
\text { 54c; V.C. 12; } \\
\text { VII.C. 373- } \\
\text { 373a; } \\
\text { VIII.B.60-60a- } \\
\text { 60c; } \\
\text { VIII.C.133; } \\
\text { XI.C.5-5a; } \\
\text { VII.C.372- } \\
\text { 372a-372b; } \\
\text { II.A.55-55a, } \\
\text { 61; III.C.79; } \\
\text { V.B.16-16a- } \\
\text { 16b; VI.D. 17- } \\
\text { 17a; VII. B.21- } \\
\text { 21a; }\end{array}$ \\
\hline Thymelaeceae & $\begin{array}{l}\text { Phaleria macrocarpa } \\
\text { (Scheff.) Boerl. }\end{array}$ & $\begin{array}{l}\text { Simalakamama } \\
\text { hkota dewa }\end{array}$ & $\begin{array}{c}\text { HeLa } \\
\text { 3T3 }\end{array}$ & Subfraction & $\begin{array}{l}132 \\
158\end{array}$ & $\begin{array}{l}\text { (Othman et al. } \\
\text { 2014) }\end{array}$ & $\begin{array}{c}\text { III. Contains 2,6,4'- } \\
\text { trihydroxy-4- } \\
\text { methoxybenzophenone and } \\
6,4^{4} \text {-dihydroxy-4- } \\
\text { methoxybenzophenone-2- } \\
\text { O- } \beta \text {-D-glucopyranoside }\end{array}$ & W. Java & N/A & $\begin{array}{l}\text { IX.A.162- } \\
\text { 162a-162b. }\end{array}$ \\
\hline
\end{tabular}




\begin{tabular}{|c|c|c|c|c|c|c|c|c|c|c|}
\hline Verbenaceae & Lantana camara L. & Saliara, stekan & Huh7 & Crude & 24.8 & $\begin{array}{l}\text { (Bisi-Johnson } \\
\text { et al. 2011; } \\
\text { Arbiastutie et } \\
\text { al. 2017; } \\
\text { Chanchal et al. } \\
\text { 2018) }\end{array}$ & II & $\begin{array}{l}\text { Trop. } \\
\text { America }\end{array}$ & N/A & $\begin{array}{l}\text { IV.C.52; } \\
\text { VI.B.13-13a. }\end{array}$ \\
\hline Violaceae & Viola odorata $\mathrm{L}$. & Bunga violet & MCF7 & Subfraction & 9.96 & $\begin{array}{l}\text { (Gerlach et al. } \\
\text { 2010) }\end{array}$ & $\begin{array}{c}\text { II } \\
\text { Contains cycloviolacin O2 }\end{array}$ & $\begin{array}{l}\text { Asia, } \\
\text { Europe, } \mathrm{N} \text {. } \\
\text { Africa }\end{array}$ & N/A & I.D.26. \\
\hline Vitaceae & $\begin{array}{l}\text { Leea indica (Burm. } \\
\text { f.) Merr. }\end{array}$ & N/A & $\begin{array}{c}\text { MCF } 7 \\
\text { KB }\end{array}$ & Crude & $\begin{array}{l}138.1 \pm 19.2 \\
146.9 \pm 10.4\end{array}$ & $\begin{array}{l}\text { (Hsiung and } \\
\text { Kadir, 2011) }\end{array}$ & III & C. Java & $\begin{array}{l}\text { LC }(\mathrm{Ye}, \\
\text { BGCI and } \\
\text { IUCN, } \\
2019)\end{array}$ & IX.A.78. \\
\hline Xanthorrhoeaceae & $\begin{array}{l}\text { Hemerocallis minor } \\
\text { Mill. }\end{array}$ & Small day lily & HeLa & Crude & N/A & $\begin{array}{l}\text { (Fan et al. } \\
\text { 2017) }\end{array}$ & IV & E. Asia & N/A & $\begin{array}{l}\text { I.E.1-1a; } \\
\text { I.G.51. }\end{array}$ \\
\hline Xanthorrhoeaceae & $\begin{array}{l}\text { Hemerocallis fulva } \\
\text { (L.) L. }\end{array}$ & Daylily & $\begin{array}{c}\text { MCF7 } \\
\text { SF-268 } \\
\text { HCT-116 } \\
\text { NCI-H460 }\end{array}$ & Subfraction & $\begin{array}{l}1.8 \pm 0.2 \\
2.4 \pm 1.8 \\
5.0 \pm 0.3 \\
3.8 \pm 0.3\end{array}$ & $\begin{array}{l}\text { (Cichewizs, } \\
\text { 2006) }\end{array}$ & $\begin{array}{c}\text { I.A } \\
\text { Contains kwanzoquinones } \\
\text { A, B, C, and E }\end{array}$ & $\begin{array}{l}\text { E. Siberia, S. } \\
\text { Japan }\end{array}$ & N/A & $\begin{array}{l}\text { I.D.8; I.E.4; } \\
\text { I.G.49; I.K.75. }\end{array}$ \\
\hline Xanthorrhoeaceae & $\begin{array}{l}\text { Aloe arborescens } \\
\text { Mill. }\end{array}$ & N/A & N/A & N/A & N/A & $\begin{array}{l}\text { (Lissoni et al. } \\
\text { 2009) }\end{array}$ & $\begin{array}{l}\text { IV } \\
\begin{array}{c}\text { Biochemotherapy with } \\
\text { cisplatin }\end{array}\end{array}$ & N/A & $\begin{array}{c}\text { LC } \\
\text { (Martínez } \\
\text { 2019) }\end{array}$ & POT.17. \\
\hline Xanthorrhoeaceae & Aloe ferox Mill. & Bitter aloe & $\begin{array}{l}\text { HeLa } \\
\text { CEM }\end{array}$ & Subfraction & N/A & $\begin{array}{l}\text { (Pecera et al. } \\
\text { 2000; } \\
\text { Chanchal et al. } \\
\text { 2018) }\end{array}$ & $\begin{array}{l}\text { II } \\
\text { Contains aloe-emodin, } \\
\text { emodin, aloin }\end{array}$ & S. Africa & N/A & IV.B.32. \\
\hline Xanthorrhoeaceae & $\begin{array}{l}\text { Aloe vera }(\mathrm{L} .) \\
\text { Burm.f. }\end{array}$ & Lidah buaya & HepG2 & Crude & $10.45 \pm 0.31$ & $\begin{array}{c}\text { (Shalabi et al. } \\
\text { 2015) }\end{array}$ & II & N/A & N/A & III.14. \\
\hline Zingiberaceae & $\begin{array}{l}\text { Etlingera elatior } \\
\text { (Jack) R.M.Sm. }\end{array}$ & Torch Ginger & $\begin{array}{l}\text { CEM-SS } \\
\text { MCF7 } \\
\text { B16 }\end{array}$ & Crude & $\begin{array}{c}4 \\
6.25 \\
15\end{array}$ & $\begin{array}{l}\text { (Habsah et al. } \\
\text { 2005; } \\
\text { Krajarng et al. } \\
\text { 2017) }\end{array}$ & I.A & Aceh & $\begin{array}{l}\text { LC } \\
\text { (Poulsenan } \\
\text { d Olander, } \\
\text { 2019) }\end{array}$ & I.K.102. \\
\hline Zingiberaceae & $\begin{array}{c}\text { Hedychium } \\
\text { coronarium J.Koenig }\end{array}$ & $\begin{array}{l}\text { Gandasuli, } \\
\text { white ginger }\end{array}$ & $\begin{array}{l}\text { LNCaP } \\
\text { HepG2 }\end{array}$ & Subfraction & $\begin{array}{l}20.42 \\
17.39\end{array}$ & $\begin{array}{l}\text { (Endringer et } \\
\text { al. 2014) }\end{array}$ & $\begin{array}{c}\text { II } \\
\text { Contains ethoxycoronarin } \\
\text { D and isocoronarin D }\end{array}$ & India & N/A & VI.C.6. \\
\hline
\end{tabular}

